\title{
Dynamics of phytoplankton groups in three contrasting situations of the open NW Mediterranean Sea revealed by pigment, microscopy, and flow cytometry analyses
}

$\underline{\text { Mikel Latasa }}^{a}$, Renate Schareka , Xosé Anxelu G. Morán ${ }^{a, b}$, Andrés GutiérrezRodríguez $^{c}$, Mikhail Emelianov ${ }^{d}$, Jordi Salat ${ }^{d}$, Montserrat Vidal ${ }^{e}$, Marta Estrada ${ }^{d}$

a Centro Oceanográfico de Gijón/Xixón (IEO-CSIC), Avda. Príncipe de Asturias 70bis, 33212, Gijón/Xixón, Asturias, Spain

${ }^{b}$ King Abdullah University of Science and Technology (KAUST), Thuwal, Saudi Arabia

${ }^{c}$ National Institute of Water and Atmospheric research (NIWA), 301 Evans Bay, Hataitai, Wellington, New Zealand

d Institut de Ciències del Mar (CSIC), Pg. Marítim de la Barceloneta, 37-49, 08003, Barcelona, Catalunya, Spain

e Departament de Biologia Evolutiva, Ecologia i Ciències Ambientals. Facultat de Biologia, Universitat de Barcelona (UB). Av. Diagonal, 643, 08028. Barcelona, Catalunya, Spain

Corresponding author: mikel.latasa@ieo.es

Keywords: HPLC, CHEMTAX, spring bloom, Synechococcus bloom, ecological preferences, size distribution Regional index terms: NW Mediterranean Sea, Gulf of Lions 
1 ABSTRACT

2

A detailed study of phytoplankton composition and dynamics was carried out during three contrasting situations (cruises F1, F2, and F3) in the northwestern (NW) Mediterranean Sea. Haptophytes, diatoms, and green algae dominated in F1, during the spring bloom, with high nutrients and high phytoplankton biomass. In F2, the post-bloom situation with a still weak stratification and lower nutrient concentrations, we found a high spatial variability. Stations were clearly dominated by either Synechococcus, haptophytes or cryptophytes; with Synechococcus reaching the highest abundance $\left(4 \times 10^{5}\right.$ cells $\mathrm{mL}^{-1}, 60 \%$ of the integrated chlorophyll a) reported to date for the open Mediterranean Sea. Cryptophytes accumulated close to the surface in very shallow mixed layer stations. In late summer, F3 revealed a fully developed stratification with low nutrients and a marked deep chlorophyll maximum (DCM). Prochlorococcus was present only during this cruise, mainly in deep layers together with haptophytes and pelagophytes, while haptophytes and Synechococcus dominated the upper mixed layer. Flow cytometry (FCM) and pigment-based abundance estimates for Prochlorococcus, Synechococcus and cryptophytes were well correlated, as happened also between small picoeukaryotes (FCM) and green algae (pigments), and between large picoeukaryotes (FCM) and haptophytes (pigments).

Dinoflagellate abundance by microscopy and by pigments did not agree well, probably due to the presence of heterotrophic forms or because they contained pigments other than peridinin, the standard dinoflagellate marker. The decrease in size of the FCM large picoeukaryotes group with depth was presumably related to the increasing contribution of pelagophytes, with smaller cells than haptophytes, 
the other main component of this fraction. Cell size increase of Prochlorococcus and Synechococcus with depth suggests vertical segregation of genotypes or photoadaptation. The groups' ecological preferences are presented with respect to depth and nutrient concentrations. Synechococcus and cryptophytes occupied shallow layers; diatoms, green algae and Prochlorococcus showed a tendency for deep layers and pelagophytes for even deeper layers, while haptophyte and dinoflagellate allocations were less clear. As for nutrients, the maximum relative contributions of green algae and especially diatoms occurred when dissolved inorganic phosphorus (DIP) concentrations were highest, of Prochlorococcus, dinoflagellates and pelagophytes when lowest, and of Synechococcus and cryptophytes when DIP concentrations were low but not minimal. The contribution of haptophytes did not show a relationship with DIP concentration. These results from individual groups stand as significant exceptions to the general relationship between phytoplankton cell size and nutrient availability.

\section{INTRODUCTION}

The composition of phytoplankton has profound implications for the functioning of marine ecosystems. Taxonomic affiliation and size are among the most important traits in determining the role of phytoplankton in aspects such as physiology, ecology, or biogeochemistry. The NW Mediterranean Sea is an excellent system for studying phytoplankton in relation to the environment. The hydrodynamics of the area share the characteristics of both temperate and subtropical oceans and have clear consequences on the composition and succession of phytoplankton. In the NW Mediterranean, this succession has been described in considerable detail 
using oceanic (Marty et al., 2002) and coastal time series (Gutiérrez-Rodríguez et al., 2011; Nunes et al., 2018) or relating the dynamics of phytoplankton groups and hydrographic conditions (Bustillos-Guzman et al., 1995). Briefly, these studies have shown a situation of water column mixing in late autumn and winter with moderate concentrations of chlorophyll a (chl a) and a phytoplankton community dominated by green algae, haptophytes, and diatoms. In late winter to early spring, a bloom of diatoms and haptophytes with a notable presence of green algae coincides with the beginning of stratification. From this moment on, increasing stratification leads to a progressive decrease in phytoplankton biomass together with an increase in the relative contribution of haptophytes and a substitution of diatoms and green algae by cyanobacteria, mainly Synechococcus in early summer and then Prochlorococcus in autumn. The cycle closes with a stepwise break in the stratification due to autumn storms and a return to the winter situation. In all this cycle, the contribution of other phytoplankton groups is low except for some sporadic increases. The studies cited above revealing these dynamics are based on the High-Performance Liquid Chromatography (HPLC) analysis of phytoplankton group marker pigments, but there are other works using different techniques that reinforce and add detail to this image. For instance, the prevalence of Phaeocystis, a key genus with an important role in oceanic biogeochemical fluxes (Schoemann et al., 2005; Verity et al., 2007), could be revealed in haptophyte blooms reported in the area with the higher taxonomic resolution of microscopy (Arin et al., 2013; Estrada, 1991).

The chemotaxonomic pigment approach has recognized advantages and disadvantages. Among the main advantages are that it captures the entire 
phytoplankton community and that with appropriate protocols it can be operator independent. Among the disadvantages are its low taxonomic detail (usually only to class level), its lack of an exact correspondence between taxonomy and pigments, and its reference to phytoplankton biomass as chl a. Despite this, it is the main technique used to differentiate phytoplankton groups in global studies or timeseries (Anderson et al., 2008; Kramer and Siegel, 2019; Schofield et al., 2017; Uitz et al., 2006). Microscopy, flow cytometry (FCM) and molecular approaches are commonly applied for the study of phytoplankton composition, while other new techniques such as LISST (Laser In-Situ Scattering and Transmissometry), FISH (Fluorescence In Situ Hybridization) or imaging flow cytometry, have shown great promise but are not yet widespread for routine use (Cabello et al., 2016; Hrycik et al., 2019; Leroux et al., 2018). Microscopy offers the best quantitative taxonomic resolution but it depends heavily on operator expertise, presents optical limitation for small size organisms $(<5 \mu \mathrm{m})$, routinely uses fixatives that can affect morphology and sample preservation (Caron, 1983), and maintains a low throughput. Flow cytometry is very widespread as it is a relatively simple, fast, and cheap technique and has no bias in picoplankton counting. As a disadvantage, it might suffer the effect of preservatives, it is routinely used to count only pico- and small nanoplankton $(<5 \mu \mathrm{m})$, and its taxonomic resolution is limited to Prochlorococcus and Synechococcus cyanobacteria, and small cryptophytes, although it has occasionally been applied to identify also coccolithophores (von Dassow et al., 2012). Molecular techniques are advancing rapidly and their potential advantages are enormous, although uncertainties associated with commonly used DNA amplification (PCR) or gene copy number variability limits the results to a semi-quantitative approach. In conclusion, the shortcomings of each 

125

technique mean that their combined use provides a great improvement for the study of phytoplankton.

In this study, we use pigments, microscopy and flow cytometry to present a detailed view of phytoplankton composition in three contrasting, well-defined situations of the annual cycle in the NW Mediterranean comprising the MEDOC area centered at $42^{\circ} \mathrm{N}, 5^{\circ} \mathrm{E}$, where deep winter convection often mixes the whole water column down to the bottom, at more than 2000 m depth (MEDOC Group, 1970). By combining these techniques, we confirm not only the general dynamics of phytoplankton in the area, but also describe exceptional findings, e.g. the absolute dominance of certain groups during the post-bloom period. Weaknesses of standard techniques for phytoplankton studies are also identified, such as discrepancies in estimates of nanophytoplankton or autotrophic dinoflagellate biomass, for the resolution of which some alternatives are offered. Finally, the ecological preferences of the different phytoplankton groups with respect to depth and nutrient concentrations are revealed and discussed in the context of other ecological features.

\section{MATERIAL AND METHODS}

\subsection{Sampling}

This study was conducted in 2009 during three different cruises on board the R/V 124 Sarmiento de Gamboa within the framework of the FAMOSO project. FAMOSO 1 (F1, 6 -23 of March) sampled the pre-bloom to bloom transition, FAMOSO 2 (F2, 
29 April - 14 May) the post-bloom period, and FAMOSO 3 (F3, 14 - 22 of

127 September) a fully developed stratification period. The three cruises surveyed a small area of about $100 \times 100 \mathrm{~km}$ (Fig. 1), far from coastal fronts and centered in a distinct oceanic province of the Mediterranean Sea (D'Ortenzio and Ribera D'Alcalà, 2009). Conductivity, temperature, and depth (CTD) data were obtained with a SeaBird 911Plus multiparametric probe, with additional sensors to measure dissolved oxygen concentration, fluorescence, turbidity, light transmission, and Photosynthetically Active Radiation (PAR) attached to a rosette frame. The water sampling was performed with $24 \mathrm{~L}$ Niskin bottles. The sampling strategy was designed for the study of vertical fluxes and adopted a Lagrangian approach.

Drifting particle interference traps were deployed, and their movements were followed during $72 \mathrm{~h}$. Therefore, the intra-cruise variability reflects both spatial and temporal changes between stations and within a particular water body. Additional details on sampling can be found in Estrada et al. (2014). The correct functioning of the conductivity and dissolved oxygen sensors was monitored by analysis of a selected number of water samples using onboard salinometer Portasal and Winkler titration methodology, respectively. Oceanographic parameters and their derived variables (e.g. Brunt-Väisälä frequency) were visualized through Ocean Data View software (Schlitzer, 2016). The Mixed Layer Depth was defined as the depth where the density was $0.03 \mathrm{~kg} \mathrm{~m}^{-3}$ higher than at the $5 \mathrm{~m}$ reference depth.

Integrated values of primary or derived variables obtained by the rosette discrete samples, such as nutrient concentrations or phytoplankton biomass (chl a and C), were estimated for the water column down to a reference depth (usually $100 \mathrm{~m}$ ) following the trapezoidal rule. For the average values in the water column, the integrated values were divided by the reference depth. 
2.2. Nutrients and fluorometric chlorophyll a

Samples for inorganic nutrient analyses were collected at 4-6 depths in the upper $100 \mathrm{~m}$ in pre-cleaned $(10 \% \mathrm{HCl}$ washed and Milli-Q water rinsed) $1 \mathrm{~L}$ polycarbonate bottles. Samples for dissolved inorganic phosphorus ( $\left.\mathrm{PO}_{4^{3-}}, \mathrm{DIP}\right)$ and dissolved inorganic nitrogen $\left(\mathrm{NO}_{3}{ }^{-}+\mathrm{NO}_{2}{ }^{-}\right.$, DIN) were immediately filtered through precombusted $\left(450^{\circ} \mathrm{C}, 4 \mathrm{~h}\right) 47 \mathrm{~mm}$ diameter glass fiber filters (Whatman GF/F) in an acid-cleaned glass filtration system, under low $\mathrm{N}_{2}$-flow pressure. Dissolved inorganic phosphorus $\left(\mathrm{PO}_{4}{ }^{3-}, \mathrm{DIP}\right)$ was determined spectrophotometrically on board using a 10 $\mathrm{cm}$ cuvette to increase the detection limit to $0.01 \mu \mathrm{mol} \mathrm{L}^{-1}$, while water samples for the determination of dissolved inorganic nitrogen $\left(\mathrm{NO}_{3}{ }^{-}+\mathrm{NO}_{2}{ }^{-}\right.$, DIN) were stored in acid-cleaned $60 \mathrm{ml}$ polycarbonate bottles at $-20^{\circ} \mathrm{C}$ for later analysis on land with an AA3 autoanalyzer (detection limit of $\left.0.03 \mu \mathrm{mol} \mathrm{L}^{-1}\right)$. Silicate $\left(\mathrm{SiO}_{4}{ }^{3-}\right)$ determinations failed and are unavailable for the FAMOSO cruises. Methods were as described in Grasshoff et al. (1999).

For fluorometric chl a analysis, $100 \mathrm{~mL}$ water samples from 6 - 8 depths between surface and $100 \mathrm{~m}$ depth were filtered through $25 \mathrm{~mm}$ diameter glass fiber filters (Whatman GF/F) under low vacuum. Filters were frozen for several hours and subsequently placed in $10 \mathrm{~mL}$ of $90 \%$ acetone and kept at $-20^{\circ} \mathrm{C}$ overnight. Fluorometric chl a was estimated from fluorescence readings in a Turner Design fluorimeter calibrated with chl a standard (Sigma-Aldrich). No phaeopigment correction was applied. 
Samples $(1.8 \mathrm{~mL})$ for flow cytometry determination of picophytoplankton abundance

and biomass were collected at 5 to 9 depths in the upper $100 \mathrm{~m}$. After fixing with 1\% paraformaldehyde and $0.05 \%$ glutaraldehyde and being kept $10 \mathrm{~min}$ at $4^{\circ} \mathrm{C}$ in the dark, samples were deep frozen in liquid $\mathrm{N}_{2}$ and stored at $-80^{\circ} \mathrm{C}$ until further analysis. Most analyses were performed on board using a FACSAria (BD Biosciences) flow cytometer equipped with a laser emitting at $488 \mathrm{~nm}$. Additional analyses were performed on a similar FACSCalibur (BD Biosciences) flow cytometer at the IEO lab in Gijón/Xixón, for which a flow rate calibration was performed daily to estimate the abundance of the different groups. After thawing at room temperature, the samples

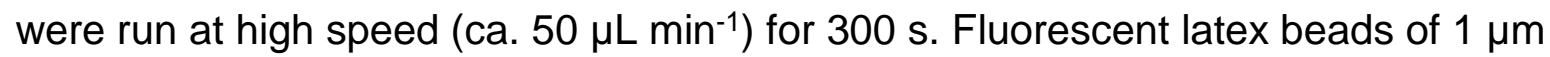
diameter (Molecular Probes) were used as internal standard. Prochlorococcus and Synechococcus cyanobacteria, cryptophytes, and large and small picoeukaryotes were distinguished based on the different red fluorescence, orange fluorescence and forward angle light scatter or side scatter (SSC) signal as described in detail in Calvo-Díaz and Morán (2006). Picophytoplankton cell volume was estimated through the empirical calibration between SSC and cell diameter of Calvo-Díaz and Morán (2006), assuming spherical shapes (Table S1). Finally, the conversion between cell volume and carbon content used the values suggested by Worden et al. (2004),

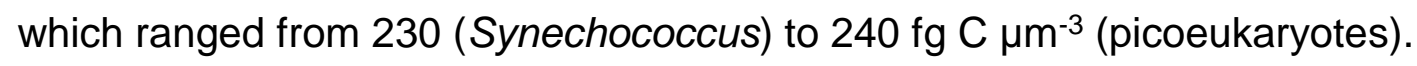

\subsection{Microscopy Analysis}

Samples for micro- and nanophytoplankton (> $2 \mu \mathrm{m})$ microscopy were taken at 2 to 4 depths including the mixed layer and deep chlorophyll maximum (DCM) and fixed 
201 with formaldehyde buffered with hexamine (0.6\% final concentration). Cell

202 identification was carried out to the group, genus and, when possible, to the species level with a Nikon Eclipse TE2000-S inverted microscope equipped with bright-field and phase-contrast objectives (total magnifications from $100 \times$ to 400 ) using the Utermöhl method (Utermöhl, 1958) and following the indications of HELCOM (2017). The shape of each taxon was defined according to composite geometric bodies extracted from the literature (Hillebrand et al., 1999; Olenina et al., 2006; Sun and Liu, 2003). Cell biovolume for each taxonomic unit was calculated as a revolution body considering the range of two-dimensional cell size measured in the samples. Cell biovolumes were converted to carbon (C) using the factors of Menden-Deuer and Lessard (2000).

Nano- and microphytoplankton $\mathrm{C}$ derived from microscopy were estimated only in samples from the surface and the DCM layer. To improve the vertical resolution and integrated $\mathrm{C}$ estimated for the water column down to $100 \mathrm{~m}$ we assumed that the $\mathrm{C}$ : chl a ratios were constant within the mixed and the DCM layers. First, we estimated the $\mathrm{C}$ : chl a ratios for each group in both the mixed and DCM layers. Next, we used the chl a values, sampled more frequently, to re-estimate the $C$ values for each microscopy-defined phytoplankton group. Finally, we integrated phytoplankton C in the water column down to $100 \mathrm{~m}$ depth for each group. Autotrophy was determined according to the genera or if plastids could be observed in the cells. However, there was a major proportion of dinoflagellates (mostly athecate) for which neither taxonomic affiliation nor chloroplast presence could be defined. To estimate the autotrophic dinoflagellate $\mathrm{C}$ in the $>20 \mu \mathrm{m}$ fraction, we applied a factor for each of the cruises based on the $\mathrm{C}$ in identified genera considered as generally autotrophic 
(Margalefidinium (formerly Cochlodinium), Oxytoxum, Tripos (formerly Ceratium or Neoceratium), Gymnodinium, Amphidinium...) and generally heterotrophic (Gyrodinium, Protoperidinium, Dinophysis...). The autotrophs/total ratio from the identified genera averaged for each cruise (0.61 in F1, 0.49 in F2 and 0.40 in F3) was multiplied by the total (autotrophs, heterotrophs plus unknown) dinoflagellates of each sample to obtain the $C$ estimates of autotrophic dinoflagellates in the $>20 \mu \mathrm{m}$ fraction. Despite averaging produced a loss of information, it provided more robustness to the data by reducing uncertainty of the individual samples due to low counts of well-identified dinoflagellate species. For the $<20 \mu \mathrm{m}$ fraction, cells were mostly counted as flagellates except when clear morphologies could be recognized, e.g. dinoflagellates or coccolithophores. A $50 \%$ of autotrophic C was assigned to the $<20 \mu \mathrm{m}$ fraction of flagellates and dinoflagellates based on the literature (Table 1 in Christaki et al. (1999), Fig. S2 in Edwards (2019), Fig. 7 in Aytan et al. (2018))

\subsection{HPLC Pigment Analysis}

Pigment concentrations were estimated by HPLC analysis from samples obtained at 4 to 6 selected depths including always the mixed and DCM layers. Two-liter water samples were filtered through glass fiber filters (Whatman GF/F), which were folded, blotted dry and stored in liquid nitrogen on board and at $-80^{\circ} \mathrm{C}$ later in the laboratory. For pigment extraction, filters were placed in $2.5 \mathrm{~mL}$ of $90 \%$ acetone, sonicated and stored at $-20^{\circ} \mathrm{C}$ overnight, and the extract was subsequently filtered through Whatman GF/F filters. Samples were run in an Agilent (Waldbronn, Germany) HPLC 1200 system with a G1311A quaternary pump, a G2258A autosampler, a G1316B column thermostat, and a G1315C diode array detector. 
251 Absorption signals recorded were $472 \pm 8 \mathrm{~nm}$ for carotenoids and $650 \pm 40 \mathrm{~nm}$ for 252 chlorophylls. The separation method was based on Zapata et al. (2000) with slight modifications. Solvent A was methanol: acetonitrile: $0.05 \mathrm{~mol} \mathrm{~L}^{-1}$ aqueous pyridine solution ( $\mathrm{pH}=5), 50: 25: 25$ (v:v:v); solvent $B$ was acetonitrile: methanol: acetone, 60:20:20 (v:v:v). The mobile phase gradient was (minutes, \%A, \%B): $(0,100 \%$, 0\%), (4, 90\%, 10\%), (19, 62\%, 38\%), (26, 20\%, 80\%), (38, 0\%, 100\%), (45, 0\%, $100 \%$ ). Flow rate was kept at $1 \mathrm{~mL} \mathrm{~min}{ }^{-1}$ and temperature at $25^{\circ} \mathrm{C}$. Spectra obtained with the absorption detector showed that during F3 the peak corresponding to the alloxanthin retention time was a 19'hexanoiloxyfucoxanthin (19'hex-fuco) derivative, revealing that our method could not separate alloxanthin from this contaminant. Because of the high correlation between 19'hex-fuco and its derivative $\left(r^{2}=0.94\right)$, we used the 19 'hex-fuco measurements to calculate the concentration of this contaminant and subtracted its contribution from the alloxanthin + contaminant peak to obtain the alloxanthin values for F1 and F2 samples.

\subsection{Pigment Data Treatment and CHEMTAX Analysis}

For exploring and organizing the pigment data, samples were clustered according to the value of the logarithm of pigment to chl a ratios of the following pigments: chl $c_{3}$, chl $c_{2}$, peridinin, 19 'butanoiloxyfucoxanthin, fucoxanthin, 19'hexanoiloxyfucoxanthin, alloxanthin, zeaxanthin, chl $b$, prasinoxanthin and divinyl chl $a$. When accessory pigment concentrations were below detection, the zero value of the pigment ratio was substituted by $1 / 3$ of the minimum value of that ratio for the whole series to avoid indetermination of the logarithm. The clustering 
276 was based on the Pearson r correlation as distance and using the Ward clustering

method (Statistica software). Pigment clustering analysis distinguished 5 major sample associations, which included samples from one or more cruises (Fig. S1).

During F1 there were 2 associations of phytoplankton pigments, in F2 there were 4 associations and in F3 there was one association. Cluster 1 samples were located only in the mixed layer during F2. Clusters 2 and 5 comprised adjacent samples, containing all samples of F1, the haptophyte-dominated stations of F2 (see below), and DCM and deeper samples in other stations of F2. Cluster 3 comprised samples only from the upmost surface layer in F2. Cluster 4 comprised exclusively all the samples of F3.

CHEMTAX analysis was applied separately to each cluster of samples following the procedures of Latasa ( 2007) to estimate the contribution of cryptophytes, diatoms, dinoflagellates, green algae, haptophytes, pelagophytes, Synechococcus and Prochlorococcus to the total $\mathrm{chl}$ a. The final outputs of pigment to chl a ratios used to calculate the contribution of each group to total chl a concentration are shown in Table S2. From now on, the chl a ascribed to each group by this CHEMTAX procedure will be used as an estimator of biomass, rather than FCM and microscopy-derived C. We decided to use pigments as the basis of our comparative study because it is the only method that encompasses the whole phytoplankton community, making the comparison between groups more consistent.

\subsection{Phytoplankton Size Fractions}


300 Phytoplankton size fractions were estimated independently using pigments (chl a based) and microscopy plus FCM (C-based). For the pigment approach the different taxonomic groups were associated to nominal size fractions following Vidussi et al. (2001), i.e. Prochlorococcus, Synechococcus and green algae were considered as picoplankton $(<2 \mu \mathrm{m})$; haptophytes, pelagophytes and cryptophytes as nanoplankton $(2-20 \mu \mathrm{m})$; and diatoms and dinoflagellates as microplankton ( $>20$ $\mu \mathrm{m})$. Thus, the groups quantified with CHEMTAX were separated into size classes according to this classification. For comparison, we also applied the Uitz et al. (2006) approach (hereafter UITZ), a widely used method based on pigments for estimating the contribution of the three size fractions. Unlike CHEMTAX, this approach gives fixed weights (coefficients) to the groups' marker pigments. In addition, we used Solver in Excel to propose new coefficients for the UITZ approach to fit the groups contributions obtained with CHEMTAX. The target of Solver was to change UITZ coefficients to minimize the sum of the 1-slopes (i.e. the divergence from the $1: 1$ line) and intercepts between CHEMTAX and UITZ results. Slopes larger than 0.92 and intercepts less than $10 \mathrm{ng} \mathrm{L}^{-1}$ were the only constraints of the model. Because we realized that the output was sensitive to the initial values of the coefficients, we started with a value of 1 for all pigment-marker to chl a ratios, since we dealt with major accessory pigments with concentrations comparable to chl a.

Phytoplankton C contribution to size fractions was estimated by microscopy and FCM as described above.

\subsection{Ecological preferences}


The relative contribution of the different groups as a function of nutrient concentration (DIP and DIN) and depth, down to $100 \mathrm{~m}$, was examined to reveal their ecological preferences. The general patterns were described by means of a smooth function (SigmaPlot software). The chosen smoothing method was a Negative Exponential, a Gaussian function to weight the data and a linear fit in our case. The parameters used were: Interval = 25, Bandwidth $=$ nearest neighbor, sampling proportion $=4$, polynomial degree $=1$ (linear regression). These parameters indicate that there are 25 points (locations or depths in our case) for the x-axis (i.e., every c.a. $4 \mathrm{~m}$ for the $100 \mathrm{~m}$ water column), and $0.4(40 \%)$ of the data from the closest depths (weighed by the Gaussian function) were used in the smoothing process at each depth. The chosen values represent a compromise between too jagged and too smoothed lines.

\section{RESULTS}

The hydrographic conditions of the cruises went from almost complete mixing of the water column during the initial stations of $\mathrm{F} 1$ to a pronounced stratification in F3, with a somehow intermediate situation in F2 (Fig. 2). Potential density $\left(\sigma_{0}\right)$ in the upper layer decreased gradually from F1 to F2 to F3, as it became warmer and slightly less saline (Fig. S2). Consequently, the water column stability, expressed by the Brunt-Väisälä frequency, followed the same evolution, with highest values during F3 between 30 and $50 \mathrm{~m}$, at the strong thermocline of the fully developed stratification (Figs. 2 and S2). Superimposed to the seasonal variability, there was substantial mesoscale heterogeneity, as shown by the near-surface high salinity waters between stations 21 and 24 in F1, the low salinity waters in the upper layers 
of stations 11-15 in F2, and the slightly lower temperatures and higher salinities at 350 the surface in the last two stations of F3 (Fig. S2).

The concentration of dissolved inorganic nitrogen (DIN) and phosphorus (DIP) in the upper mixed layer decreased from F1 to F2 to F3 (Fig. 2, Table 1). Surface DIN concentration was always above $3 \mu \mathrm{mol} \mathrm{L}{ }^{-1}$ during $\mathrm{F} 1(5.1 \pm 2.1$, mean \pm S.D., $\mathrm{n}=8)$, decreasing to $1-4 \mu \mathrm{mol} \mathrm{L}^{-1}$ in $\mathrm{F} 2(1.9 \pm 1.0, \mathrm{n}=14)$, and to $0.7-2.1 \mu \mathrm{mol} \mathrm{L}^{-1}$ in F3 $(1.7 \pm 0.5, n=5)$. DIP followed the same temporal and spatial pattern as DIN, with concentrations in the upper mixed layer ranging from $0.06-0.36 \mu \mathrm{mol} \mathrm{L}^{-1}$ in $\mathrm{F} 1$ $(0.16 \pm 0.11, \mathrm{n}=10), 0.009-0.080 \mu \mathrm{mol} \mathrm{L}^{-1}$ in $\mathrm{F} 2(0.030 \pm 0.022, \mathrm{n}=14)$ and 0.016 $0.049 \mu \mathrm{mol} \mathrm{L}^{-1}$ in F3 $(0.032 \pm 0.012, \mathrm{n}=6)$. Median DIN/DIP ratios in surface waters (excluding ratios with DIP $<0.01 \mu \mathrm{mol} \mathrm{L}^{-1}$ ) were 35,55 and 43 for $\mathrm{F} 1, \mathrm{~F} 2$ and $\mathrm{F} 3$, respectively.

Except for the first biological station (F1-08), which presented strong deep winter mixing and low chl a concentrations (Fig. 3), the F1 cruise sampled the winterspring bloom situation, with a weak stratification, high nutrients and enhanced phytoplankton biomass distributed quite homogeneously in the upper $40 \mathrm{~m}$ layer (Fig. 2). The average chl a concentration during F1 was $0.84 \mu \mathrm{L} \mathrm{L}^{-1}$ in the upper $100 \mathrm{~m}$ (Table 2). The most abundant phytoplankton groups according to their contribution to chl a were haptophytes (32\%), diatoms (23\%), and green algae (19\%), followed by Synechococcus (11\%), pelagophytes (9\%), dinoflagellates (4\%) and cryptophytes (2\%) (Tables 2, 3 and S3; Fig. 3). In terms of C, microscopy assessed a greater contribution of diatoms, mainly through large $(>20 \mu \mathrm{m})$ and chain forming diatoms, which made up $37 \%$ of the bulk phytoplankton (Table 2), 
and a smaller contribution of nanoflagellates $(2-20 \mu \mathrm{m}, 9 \%)$ compared to pigmentbased estimates of diatoms and haptophytes. Microdinoflagellates $(>20 \mu \mathrm{m})$ and nanodinoflagellates accounted for $5 \%$ and $2 \%$ of phytoplankton C, respectively. The dominance of diatoms was due to their overwhelming contribution $(61-73 \%$ in C) at two stations (F1-27 and F1-31, Table 4). The picophytoplankton community was composed by eukaryotes and Synechococcus, which contributed 25 and $18 \%$ of the total autotrophic $\mathrm{C}$, respectively. FCM analysis revealed very low concentrations of Prochlorococcus cells, not detected by divinyl chl a, their characteristic pigment marker.

The hydrodynamic and biological conditions during F2 (the post-bloom situation) were very heterogeneous. The stratification was weak and shallow, but stronger than in F1 (Table 1). The shallowest mixed layers of the study were found during this cruise (Table 1). Nutrient concentrations were lower than during F1 in the upper $40 \mathrm{~m}$, and the chl a concentration had decreased in relation to the latter stages of $\mathrm{F} 1$ to $0.30 \mu \mathrm{g} \mathrm{L}^{-1}$ in the upper $100 \mathrm{~m}$ (Fig. 2, Table 2). On average, Synechococcus contribution to chl a was the highest (36\%), followed by haptophytes $(25 \%)$, pelagophytes $(13 \%)$, green algae $(11 \%)$, cryptophytes $(8 \%)$ and diatoms and dinoflagellates (3\% each), which contributed the least (Fig. 3). Microscopy and FCM estimates of C (Table 2) confirmed the high contribution of Synechococcus to C (55\%) followed further behind by microdinoflagellates (14\%), nanoflagellates and picoeukaryotes ( $9 \%$ each), nanodinoflagellates ( $7 \%)$ and microdiatoms $(2 \%)$. The spatial dynamics of the phytoplankton groups during this cruise in the post-bloom period revealed some uncharted features in this area. The most striking finding was the overwhelming dominance of Synechococcus, 
reaching concentrations up to $4.2 \times 10^{5}$ cells $\mathrm{mL}^{-1}$, equivalent to $60 \%$ of the

400 integrated chl $a,>90 \%$ of the picophytoplankton $\mathrm{C}$ and $>80 \%$ of the total

phytoplankton C, at the initial stations (Figs. 3, 4 and S3, Tables 5 and S3). A weak and broad DCM was present between 30 and $60 \mathrm{~m}$ depth. Exceptions to this pattern were observed in F2-40 and, especially, F2-44, in the southern part of the studied area (Figs. 3 and S3), sampled at the end of the cruise. Here, the stratification increased, chl a concentrations were higher with a clear DCM around $50 \mathrm{~m}$, and haptophytes were the most important group representing up to $50 \%$ of the phytoplankton community (Figs. 3 and S3; Tables 3 and S3). At these stations there was also an increase of large picoeukaryotes detected by FCM (Figs. 4 and 6), and of microscopy-derived abundances of large dinoflagellates, diatoms and Mesodinium rubrum (Table 4), a ciliate with cryptophyte-type pigments. Nanophytoplanktonic flagellates also increased, but to a lesser extent. Another interesting feature was found at stations F2-20 to F2-32. We found here the shallowest mixed layers (Table 1) and abundant cryptophytes ( 20\% of integrated chl a, Figs. 3, 4, and S3) particularly in the upper layers where they tended to accumulate $(\sim 30 \%$ of chl $a$ in shallow samples). This increase agreed with high counts of nanoplanktonic cryptophytes by FCM (up to 900 cells $\mathrm{mL}^{-1}$, Fig. 4). It is worth noting the very low concentrations of diatoms during F2, especially on the stations where Synechococcus was very abundant. Diatom concentrations were similar or even lower than during the highly stratified conditions of F3 in September (Tables 2, 3 and 4). There was a discrepancy in the contribution of autotrophic dinoflagellates, which represented $3 \%$ or $21 \%$ of the phytoplankton according to pigment (chl a) or microscopy (C) data, respectively (Table 2). 
424 The F3 cruise showed a typical fully developed stratification situation of midlatitudes characterized by a thick mixed layer with low nutrient and phytoplankton concentrations (chl a 0.11 $\mathrm{g} \mathrm{L}^{-1}$ ), clearly isolated from subsurface nutrient-richer waters by a strong thermocline between 40 and $60 \mathrm{~m}$ depth. The depth of a distinct $\mathrm{DCM}\left(>0.6 \mu \mathrm{g} \mathrm{L}^{-1}\right)$ varied between 50 and $80 \mathrm{~m}$, and the average chl $a$ concentration in the upper $100 \mathrm{~m}_{\text {was }} 0.32 \mathrm{\mu g} \mathrm{L}^{-1}$ (Fig. 3, Table 2). Phytoplankton was dominated by haptophytes and Synechococcus in the mixed layer $(>40 \%$ and $>30 \%$, respectively) and by haptophytes and pelagophytes at the DCM and deeper. Prochlorococcus contribution was highest ( 30-40\%) just in the upper part of the DCM (Figs. 3 and 4). Cryptophytes were under our detection limit for pigment, FCM and microscopy analyses (Tables 3,5$)$. There was a reasonable agreement in the total contribution to the phytoplankton community as pigment or $\mathrm{C}$ (Table 2) by Prochlorococcus (23\% vs $26 \%$ ) and Synechococcus (10\% vs $17 \%$ ). As for F2, there was a discrepancy in the contribution of dinoflagellates, 5 and $35 \%$ depending on pigment or microscopy information, respectively (Table 2). Picoeukaryotes (9\%) and nanoflagellates (7\%) were the other main groups in terms of $\mathrm{C}$.

The distribution of phytoplankton in the three canonical size fractions (pico-, nanoand micro-) was different if estimated as C from FCM and microscopy, or as chl a according to CHEMTAX estimates (Table 2, Fig. 5). The major discrepancy was for nano- and microphytoplankton. On one hand, microscopy estimates of microphytoplankton contribution (which includes chain-forming diatoms smaller than $20 \mu \mathrm{m}$ ) to phytoplankton $\mathrm{C}$ were 45,20 and $28 \%$ for F1, F2 and F3, respectively. Pigment estimations rendered a substantially lower contribution of 
449 microphytoplankton to total chl a across all cruises ( $F 1=27 \%, F 2=6 \%$ and $F 3=12 \%$

Table 2). On the other hand, the estimates for the nanophytoplankton fraction were 11,16 and $20 \%$ in terms of C, markedly lower than the 43,46 and $50 \%$ obtained in terms of chl a for F1, F2 and F3, respectively. Finally, the estimates for the picophytoplankton fraction using FCM were 44,64 and $52 \%$ in terms of C, and 30 , 48 and $38 \%$ in terms of chl $a$ for F1, F2 and F3 (Table 2).

\section{DISCUSSION}

\subsection{Biomass estimates and methodological considerations}

The combination of pigments, FCM and microscopy revealed the strengths and the weaknesses of the different techniques. On the other hand, the integration of complementary techniques provides robustness to the interpretation of our results. HPLC (in the laboratory) and fluorometric estimates (on board) of chl a presented a high correlation (Fluorometric chl $a\left(\mathrm{ng} \mathrm{L}^{-1}\right)=1.10 \mathrm{HPLC}$ chl $\left.a+8.8, \mathrm{r}^{2}=0.92\right)$. The estimates of phytoplankton size fractions obtained by CHEMTAX and UITZ methods also showed a high correlation (Fig. 6). In these two pigment-based approaches, picoplankton is represented by cyanobacteria and green algae, microplankton by diatoms and dinoflagellates, and nanoplankton by the other pigment groups. The assignment of fixed sizes to taxonomic groups as well as the uncertainty caused by some phytoplankton classes sharing some marker pigments (Chase et al., 2020) makes size classification by pigments a rough approximation. It is intended to be applied with caution and preferably to large scale and global data sets, and not as an exact measure for a particular region or ecosystem (Uitz 
et al., 2006). To reduce part of this uncertainty for the NW Mediterranean, we tuned 475 the coefficients used in the original UITZ approach to fit our CHEMTAX results (see M\&M section) resulting in the following new coefficients (new/original):

cryptophytes (alloxanthin) 1.06/0.60, diatoms (fucoxanthin) 0.62/1.41, dinoflagellates (peridinin) 1.21/1.41, green algae + Prochlorococcus (chl b) 1.02/1.01, haptophytes (19'hex-fucoxanthin) $0.79 / 1.27$, pelagophytes (19'butfucoxanthin) $0.94 / 0.35$ and cyanobacteria (zeaxanthin) $1.33 / 0.86$. Figure S4 shows the results using these new coefficients. We went further to provide a slightly modified algorithm that discriminates the contribution of green algae, Prochlorococcus and Synechococcus. The resulting coefficients of the new algorithm are shown in Fig. S4. This adjustment exercise with a different methodology has been applied for other databases (Brewin et al., 2017; Di Cicco et al., 2017). Here, we provide what we consider to be better coefficients of the UITZ approach for the NW Mediterranean Sea.

There was a high correlation between abundance estimates of various phytoplankton groups (Synechococcus, Prochlorococcus and small cryptophytes) based on FCM-derived C and pigment data (Fig. 7). This comparison revealed a close relationship between FCM-derived C from small picoeukaryotes (overall cell diameter $1.45 \pm 0.12 \mu \mathrm{m}$, Table S1) and the chl a biomass of green algae (suggesting that they represented a substantial part of the picoeukaryotes). Also, the strong correlation between FCM-derived C for large picoeukaryotes (cell diameter $1.97 \pm 0.17 \mu \mathrm{m})$ and chl a from haptophytes suggests that a significant part of this nanoplanktonic group contributes to the FCM-picoplankton fraction (Fig. 7). Cabello et al. (2016), using epifluorescence observations of FISH-marked algae 
499 in the Cantabrian Sea, estimated that $88 \%$ of haptophyte and $93 \%$ of pelagophytes

cells are in the 2-5 $\mu \mathrm{m}$ fraction, largely recorded with our FCM settings (up to 4 $\mu \mathrm{m})$. Yet, there was no good correspondence between large (or small) picoeukaryotes (FCM) and pelagophytes (pigments) in our data (Fig. 4). We hypothesize that the lower contribution of pelagophytes ( $12 \%$ vs. $29 \%$ of haptophytes over all cruises) was the reason for their minor influence in the variability of the bulk of large picoeukaryotes. An interesting result was the strong correlation between pigment-based and FCM-based cryptophyte abundances (mean cell diameter of $2.4 \mu \mathrm{m}$, Table S1), indicating a considerable presence of very small cells in this group (Figs. 4 and 7 ). It is worth to note that the population dynamics of haptophytes and cryptophytes, usually considered as nanoplanktonic, are well reflected by their representatives in the FCM $<3 \mu \mathrm{m}$ fraction (Figs. 4 and 7). If this result is confirmed by other studies, it opens a window of opportunity for FCM studies since haptophytes and cyanobacteria, with a significant participation of pelagophytes, are usually the main phytoplankton components in oligotrophic areas.

The comparison between pigments and microscopy results revealed some important information. Table 2 shows that for the three situations (cruises) the contribution of nanophytoplankton is lower as C (microscopy) than as chl a. For microphytoplankton the situation is the reverse: higher contribution as $C$ than as chl a. For diatoms, a main microphytoplankton group, the contribution is rather similar as $\mathrm{C}$ or chl a (Table 2), $\mathrm{C}$ and chl a co-vary significantly (Fig. 7) and the average C: chl a ratio for the 3 cruises is $44( \pm 65, n=23$, not shown), a reasonable value for all the different environments sampled. On the other hand, the estimates for 
dinoflagellates, the other dominating microphytoplankton group, are quite intriguing. Dinoflagellate $\mathrm{C}$ and chl a do not show a correlation overall but co-vary within F1 and F2 (Fig. 7). The average C: chl a of dinoflagellates was 31, 490 and 150 for F1, F2 and F3, respectively (not shown). The very high C: chl a ratios indicate that either $\mathrm{C}$ was overestimated or chl a underestimated for dinoflagellates in F2 and F3. The presence of dinoflagellates with pigments other than peridinin, the standard pigment used here for pigment estimates, is not uncommon (Zapata et al., 2012) and would have resulted in pigment underestimation of the real contribution of dinoflagellates. On the other hand, there are some lines of evidence that indicate that dinoflagellate $\mathrm{C}$ was overestimated by microscopy, especially in the microphytoplankton fraction. First, the contribution of microphytoplankton during F2 and F3, when meso- and oligotrophic conditions prevailed, is expected to be minimal. Delgado et al. (1992) using epifluorescence microscopy estimated that the $\mathrm{C}$ contribution of nano- and microphytoplankton in stratified conditions in the area was $72 \%$ and $6 \%$, respectively. The C contributions of dinoflagellates larger than $20 \mu \mathrm{m}$ in our samples were the second highest after Synechococcus in F2 (12\%) and Prochlorococcus in F3 (23\%). Therefore, autotrophic dinoflagellate contribution in these two cruises was likely overestimated. In summary, the best explanation to our results of $\mathrm{F} 2$ and $\mathrm{F} 3$ is a combination of a significant portion of heterotrophic dinoflagellates incorrectly assigned as autotrophic and the presence of autotrophic forms with pigment markers different from peridinin.

The low $\mathrm{C}$ biomass and contribution of nanophytoplankton relative to pigmentbased values (Table 2) was intriguing. To begin with, the nanophytoplankton contribution of pigment groups is overestimated since haptophytes and 
pelagophytes (considered nanoflagellates) appear to make a substantial

contribution to the FCM picoeukaryote size fraction. In addition, the nanoplanktonic fraction was likely underestimated by microscopy because of technical limitations to observe the smallest cells in this fraction. We made an effort to count cells down to $2 \mu \mathrm{m}$ but there are some inherent difficulties such as the unsatisfactory fixation and settlement of small cells in the samples, which could contribute to the underestimation of the nanophytoplanktonic fraction by microscopy. Indeed, Leroux et al. (2018) using the Laser In-Situ Scattering and Transmissometry technique (LISST) in the same area during the spring bloom of 2013 claimed that microscopy estimates of nanoplankton could be as low as $15 \%(\sim 1 / 6)$ of the real value.

Because LISST cannot differentiate between autotrophic, heterotrophic and detritus particles, it is likely that the real underestimation by microscopy, although existing, is smaller than the values presented by these authors. Leroux et al (2018) reported that LISST overestimated traditional FCM values by a factor of 3 . Since we consider that FCM is a reliable counting method, we conclude that $\mathrm{C}$ estimates of nanophytoplankton by microscopy could be around half of the real value. In agreement with this, microscopy estimates are $30-60 \%$ of the contribution of nanophytoplankton estimated by the pigment approach (Table 2). Mena et al. (2019) also concluded that light microscopy underestimates the abundance of the nanophytoplankton fraction in comparison to epifluorescence microscopy by a factor of 2.5. By applying our correction (x2), the nanophytoplankton C contribution would increase to $28 \%$ and $33 \%$ in $\mathrm{F} 2$ and $\mathrm{F} 3$, respectively, and microphytoplankton C contribution would decrease accordingly to 17 and $23 \%$ (data not shown). Because of the apparently overlooked importance of small nanophytoplankton (Leblanc et al., 2018; Nunes et al., 2019) we suggest extending 
574 routine FCM analyses, perhaps by running the sample a second time, to include a

As a precautionary methodological note regarding the extrapolation of cell concentrations to $\mathrm{C}$ using fixed conversion values, it should be noted that changes of cell size with depth in the picophytoplankton components (Fig. 8) were very similar to those described by Latasa et al. (2017) in the Cantabrian Sea and by Mena et al. (2019) in the western Mediterranean under stratified, oligotrophic conditions. Cell size increase with depth for Synechococcus and Prochlorococcus is well known (Binder et al., 1996; Olson et al., 1990). Casey et al. (2013) suggested that this pattern in Prochlorococcus and Synechococcus is due to the fact that a larger pigment system is needed to cope with low irradiances, resulting in an increase in the size of the small cells of these groups. As an alternative, possible changes in Synechococcus or Prochlorococcus strain assemblages with depth or throughout the seasons cannot be discarded (Hunter-Cevera et al., 2016; Johnson et al., 2006; Scanlan and West, 2002). The comparison of the profiles in the different cruises (Fig. 8) indicates that the change in volume with depth is a temporal process occurring at scales of weeks or longer, which would allow the rearrangement of different clades in the water column (Malmstrom et al., 2010). On the other hand, more than to physiological or ecological responses, we attribute the decrease in size of large picoeukaryotes to the increasing contribution with depth of pelagophytes (Fig. 3), a group with smaller cell sizes than haptophytes (Cabello et al., 2016), the latter making up the bulk of FCM-defined large picoeukaryotes.

\subsection{Biomass distribution}


Total phytoplankton biomass followed the general trend described for this area and the surrounding coastal waters, with a late winter - early spring bloom and increasing oligotrophic conditions until early fall (Bosc et al., 2004; D'Ortenzio and Ribera d'Alcalà, 2009; Nunes et al., 2018). Averaging over the 3 cruises, the dominant groups in terms of pigment biomass were haptophytes followed by Synechococcus, pelagophytes, green algae, diatoms, Prochlorococcus, cryptophytes, and dinoflagellates (Table 2). The temporal patterns of variability of these groups, a bloom dominated by diatoms and haptophytes with a significant contribution of green algae, a post-bloom situation dominated by haptophytes and Synechococcus and a stratification period dominated by haptophytes, pelagophytes and Prochlorococcus was comparable to the general trends found in previous studies (Latasa et al., 2010; Marty et al., 2002).

\subsubsection{F1 Bloom}

For the discussion of the spring bloom we will leave apart the deeply mixed situation before any stratification set on ( $\mathrm{F} 1-08)$; this station had low biomass $(0.2$ $\mu \mathrm{g} \mathrm{L}^{-1}$ ) and a phytoplankton community dominated by green algae, diatoms and haptophytes, typical of winter in the area (Bustillos-Guzman et al., 1995; GutiérrezRodríguez et al., 2011; Nunes et al., 2018).

During the bloom (chl $a>0.5 \mu \mathrm{g} \mathrm{L}^{-1}$ ), there was a complex situation with haptophytes, diatoms and green algae dominating the phytoplankton community.

Mesoscale processes, baroclinic instabilities and stratification-destratification events associated to the end of deep, violent mixing episodes (Salat et al 2010), as 
624 well as some storms (the cruise had to stop twice, on March 16 and 20 because of 625 628

strong winds) produced an interleaving of high and low salinity waters in the surface layers (Estrada et al., 2014) and precluded the establishment of clear temporal or spatial patterns in water column stratification and bloom development. It appears that we sampled the early, unstable stages of the bloom onset typical of these dates (Lévy et al., 1999; Severin et al., 2014). This could explain the important contribution of green algae, a picoplanktonic group not often revealed in spring bloom studies but with increasing evidence of its important contribution during this period (e.g. Bolaños et al., 2020). The mixed dominance of diatoms and haptophytes, however, is well documented (Latasa et al., 2010; Marty et al., 2002; Severin et al., 2017). Severin et al. (2017) explained that, for their 2013 study, only stations where previous convection mixing had reached the seafloor presented silicate to nitrogen ratios high enough for diatoms to outcompete other groups. Our results seem to confirm this hypothesis. Our silica analysis failed and the relatively low number of stations (8) with little variance in nitrogen concentrations prevented us from seeing clear patterns, but the contribution of diatoms tended to be higher with higher salinities in the upper $50 \mathrm{~m}(\mathrm{p}=0.13$, data not shown) indicative of deep mixing of surface waters. Occasional samples obtained with a phytoplankton net (20 $\mu \mathrm{m}$ mesh size) were observed fresh during $\mathrm{F} 1$ and allowed us to qualitatively distinguish two plankton communities: a more mature one in which zooplankton, detritus and some Phaeocystis colonies were evident, and a younger one with presence of diatoms and healthy-looking cells, and less abundant zooplankton (Fig. S5). The presence of Phaeocystis in phytoplankton proliferations in the NW Mediterranean has already been reported in association with recently advected Atlantic waters (Estrada, 1991; Estrada et al., 1999) and shows that this genus can 
compete well with diatoms when the water column starts to stratify after shallow mixing conditions and lower Si/N ratios.

\subsubsection{F2 Post-bloom}

During the F2 post-bloom cruise in April the stratification was relatively weak and shallow (Fig. 2), nutrients in the surface layer had decreased relative to F1, and phytoplankton biomass was also lower (Table 1, 2). According to previous studies during this period in the area (Latasa et al., 2010; Marty et al., 2002; Vidussi et al., 2000) we expected a diverse community typical of pre-oligotrophic conditions, with haptophytes, pelagophytes, green algae, cryptophytes and Synechococcus making up the bulk of the phytoplankton biomass. However, we found a high spatial variability with stations clearly dominated either by Synechococcus, haptophytes or cryptophytes (Figs. 3 and S3). This spatial heterogeneity in phytoplankton group distribution during F2 was not clearly related to the environmental variables analyzed in this study. It must be noted that subtle differences in physico-chemical properties of different water bodies may be a consequence of different hydrographical histories and of distinct selection pathways of their associated phytoplankton populations.

The most unexpected result was the very high concentrations of Synechococcus in a large area, a new report for the Mediterranean Sea although Marty et al. (2002) in a 8-year time-series in the area present spikes of zeaxanthin concentration above $5 \mathrm{mg} \mathrm{m}^{-2}$ in two occasions (roughly half the values measured in F2). Except for the exceptional Costa Rica Dome, where Synechococcus concentrations can 
674 reach $10^{6}$ cells $\mathrm{mL}^{-1}$ during the summer upwelling season (Saito et al., 2005),

dominance of Synechococcus in open waters has been seldom described. To our knowledge, it has only been reported in the oligotrophic Eastern Mediterranean (Denis et al., 2010), the Arabian Sea (Bidigare et al., 1996), and the Atlantic Ocean (Partensky et al., 1996), the latter two in mesotrophic conditions. Denis et al. (2010) reported Synechococcus contributions $>60 \%$ of the ultraplankton $(<5 \mu \mathrm{m})$ biomass in an anticyclonic gyre, but with only $6 \%$ of the total chl a concentration we found in F2. Partensky et al. (1996) reported abundances up to $5 \times 10^{5}$ cells $\mathrm{mL}^{-1}$, comparable to those found here, in a community with an important contribution of diatoms, suggesting a post-bloom situation. Although the average concentration of chl $a$ in the water column during F2 was similar to that in F3 (297 vs. $318 \mathrm{ng} \mathrm{L}^{-1}$, Table 2) the surface concentration during F2 was 3-4 times higher than during F3 (Fig. 3), therefore, hinting that these waters were not as oligotrophic as indicated in terms of integrated phytoplankton biomass. Also, primary production was about 3 times higher in F2 than in F3 (Estrada et al., 2014), and additional hydrographic data (not shown) hinted at a weak deep upwelling reaching the euphotic zone in F2 (Salat et al., 2013). It is intriguing that, in coincidence, the Costa Rica Dome is a recurrent, weak upwelling system. In the coastal Mediterranean Sea, BustillosGuzman et al., (1995) found the highest Synechococcus concentrations under intermediate mixing conditions, and data from Nunes et al. (2018) in a 15-year time-series study of a coastal site in the NW Mediterranean, show a consistent peak of Synechococcus after the spring bloom. High temperature has been considered a beneficial factor since Synechococcus blooms are commonly described in coastal tropical and sub-tropical waters (Beardall, 2008), and their optimal growth temperature in the coastal NW Mediterranean has been reported at 
$699 \sim 24{ }^{\circ} \mathrm{C}$, with no growth when temperature drops below $11^{\circ} \mathrm{C}$ (Agawin et al., 1998).

700 The strong dominance of Synechococcus in the open NW Mediterranean at $15^{\circ} \mathrm{C}$ suggests that coastal clades are likely different from those found in our study area.

Hunter-Cevera et al. (2020) showed that Synechococcus reached maximum growth rates at c.a. $14{ }^{\circ} \mathrm{C}$ for the spring population in the northeast U.S. shelf. The existence of multiple strains of Synechococcus with different physiological capabilities (Pittera et al., 2014; Scanlan et al., 2009) confounds the interpretation of the ecological features of this group, often considered as a single population, highlighting the need to consider the diversity of this genus. The lower contribution of Synechococcus in the southern stations coincided with an increase in phytoplankton biomass and haptophyte contribution (Figs. 3 and S3). The only clear difference was the stronger stratification in these latter stations, further supporting that semi-mixed conditions appear as a determinant factor for the dominance of Synechococcus under nutrient limitation (Bustillos-Guzman et al., 1995). The existence of only few reports of open ocean Synechococcus blooms (Bidigare et al. 1996; Partensky et al., 1996; this study) indicates that these episodes are quite unusual and the potential factors driving them are still unclear.

Cryptophytes were especially abundant in the surface layers of some stations of F2. Significant contribution of cryptophytes in the NW Mediterranean had been reported (Estrada, 1985; Latasa et al., 1992), and Marty et al. (2002) results show 3 cruises in their 8 year time series studies with concentrations of alloxanthin around $4 \mathrm{mg} \mathrm{m}^{-2}$, in the same order as the $2.2 \mathrm{mg} \mathrm{m}^{-2}$ reached in F2 (data not shown). Flow cytometry showed a parallel increase of small cryptophytes (Figs. 4 and 7). Microscopic observation confirmed that Mesodinium rubrum, a ciliate that 
724 feeds on cryptophytes and incorporates their chloroplasts as endosymbionts, was abundant (Table 4) but its distribution differed slightly from cryptophyte pigment concentrations and FCM abundances, perhaps indicating the detrimental effect of this mixotroph on cryptophyte abundances (Johnson et al., 2013). We suspect that our previous report of cryptophytes as an eutrophic group with preference for deep waters (Latasa et al., 2010) could have been misled by the contamination of the alloxanthin peak described in M\&M section, although Marty et al. (2002) and Vidussi et al. (2000), also using pigments, reported high cryptophyte concentrations during nutrient-rich conditions. During F2, cryptophytes dominated in some northern stations (Figs. 3 and S3) without any obvious explanation except very shallow mixed layers (Table 1). High concentrations of cryptophytes have been described in estuaries usually related to low salinities (Johnson et al., 2013) and in surface layers associated to stratified, relatively low salinity water masses in coastal Antarctica (Nunes et al., 2019; Rodriguez et al., 2002; Schofield et al., 2017). Since surface salinity in cryptophyte-dominated stations in F2 was higher than in the Synechococcus-dominated stations (Fig. S2) it appears that strong shallow stratification is more important than low salinity for cryptophytes to thrive in the NW Mediterranean.

A noteworthy result was the very low concentrations of diatoms during the cruise, confirmed by microscopy (Table 4). Unfortunately, silicate samples were lost and the influence of this essential nutrient for diatoms on their dynamics cannot be assessed. Based on studies on competitive exclusion, Cermeño et al. (2011) indicated that taxa with slow nutrient uptake are favored over opportunistic taxa such as diatoms in bloom-post bloom transitions (after reduction of nutrient supply). 
Vidussi et al., (2000) in a study in the area during the same transition period suggested, based on their vertical distribution, that diatoms are more limited by phosphorus than nanophytoflagellates. In addition to nutrient dynamics, the biomass of the mesozooplankton community was the highest among the 3 cruises (Isla et al., 2015). We hypothesize that this high zooplankton presence together with low DIP concentrations produced the minimum values of diatoms found in our study. The contribution of diatoms considered as typical of summer assemblages (e.g. Leptocylindrus spp, Hemiaulus hauckii) increased appreciably from F1 to F2 but not from F2 to F3, discarding the explanation of an increase of diatoms adapted to the severe oligotrophic conditions in F3 (Table S4).

\subsubsection{F3 Stratification} especially Prochlorococcus. The low number of samples preclude a clear 
explanation, but a lower contribution of this group (Table S3) seems related with 774 higher values of DIP (Table 1).

775 The disappearance of Prochlorococcus in spring and mid-summer, their 776 reappearance in late summer and fall and persistence throughout the winter is a recurrent phenomenon in the NW Mediterranean and other temperate areas (Calvo-Díaz et al., 2008; Nunes et al., 2018). Because Prochlorococcus is a good competitor when nutrients are scarce, it is puzzling that this group is absent in the post-bloom cruise with DIP concentrations at the same level as in F3. Regarding other environmental variables such as temperature, which displayed a strong difference among cruises (Fig. S2), models (Flombaum et al 2020) indicate that Prochlorococcus contribution increases from $10^{\circ}$ to $30^{\circ} \mathrm{C}$. However, their main contribution during F3 occurred close to the DCM (up to $2 \times 10^{5}$ cells $\mathrm{mL}^{-1}$, Figs. 3 and 4) with temperatures around $16^{\circ} \mathrm{C}$ (Fig. S2) and only $2^{\circ}-3^{\circ} \mathrm{C}$ above those of F2 at the same depths. This result rules out that temperature was the main determining factor of Prochlorococcus distribution in the studied area. We can think of alternative, non-excluding hypotheses to explain their low concentrations in the spring and mid-summer period. It is likely that after being practically wiped out during the bloom conditions, the seed population in the area was too small to produce a noticeable recovery of the Prochlorococcus concentration between April and August. A suggested weak deep upwelling during F2 (Salat et al., 2013) could have produced unfavorable conditions for this group preventing its proliferation at depth. On the other hand, the UV levels, to which Prochlorococcus appears especially sensitive (Sommaruga et al., 2005), are quite high during this period probably delaying the recovery of its population at surface. The decline of picophytoplankton and Prochlorococcus populations in the surface mixed-layers 
and the DCM has been linked to increased productivity and grazing pressure on heterotrophic bacteria (Kuipers and Witte, 2000; Taylor and Landry, 2018), and could also explain the lack of Prochlorococcus in F2. In this period, heterotrophic bacteria production was very high, but their concentrations were kept in check (Gomes et al., 2015) probably by an enhanced grazing that could have helped to maintain Prochlorococcus concentrations very low. This scenario would imply that Synechococcus was less affected by grazers feeding on smaller bacteria, including Prochlorococcus.

\subsection{Groups' Ecological Preferences}

The most obvious environmental change explaining the distribution of the phytoplankton groups during the three cruises studied here was the development of the water column stratification and the associated decrease in nutrient concentrations from F1 to F3. Stratification fixes temperature, irradiance, and nutrients for phytoplankton at the different layers of the water column. The general pattern of the relative contribution of a phytoplankton group with depth, as shown in Fig. 9, indicates its depth-preference relative to the rest of the groups. As expected, vertical patterns were better defined under stratified conditions. Our results confirm previous knowledge on the relative vertical distribution of phytoplankton groups (Bracher et al., 2020; Miranda-Alvarez et al., 2020; Riegman and Kraay, 2001). Synechococcus and cryptophytes showed a strong preference for shallow layers. In contrast, diatoms, green algae, and Prochlorococcus showed a tendency for deep layers and pelagophytes for even deeper layers, while haptophyte and dinoflagellate allocation preferences were less clear. The notable presence of 
823 mixotrophic forms in these two latter groups could partly explain their relatively high 827

The concentration of nutrients at the surface has been studied as a reasonable indicator of the nutrient input into the euphotic zone (Otero-Ferrer et al., 2018), but there was no clear relationship of DIP at $5 \mathrm{~m}$ with either the absolute concentration or the relative contribution of each phytoplankton group (data not shown). Some patterns appear, however, when comparing the groups' contribution with the DIP integrated over 100 m depth (Fig. 10). Thus, Prochlorococcus, dinoflagellates and pelagophytes made the highest contribution when DIP was lowest. Synechococcus and cryptophytes made their maximum contribution to the phytoplankton community when DIP concentrations were low but not minimal. The contribution of haptophytes did not show a relationship with DIP concentration, while the contributions of green algae and specially diatoms were maxima when nutrient concentrations were highest. Similar patterns could be observed when using DIN as the reference nutrient (Fig. S6) This group distribution can be recognized in the trophic classification established by Latasa et al. (2010), although with some differences. In the present study, diatoms and green algae emerge again as the most eutrophic groups, Prochlorococcus as the most oligotrophic one and Synechococcus and haptophytes as typically mesotrophic. However, pelagophytes and dinoflagellates contribute more when nutrients are low, while in Latasa et al. (2010) these groups were considered as mesotrophic and eutrophic, respectively. 845 There could be some explanations for this discrepancy. Nunes et al. (2018) observed an increasing trend in the contribution of pelagophytes in a coastal site of the NW Mediterranean when nutrient input decreased, therefore reinforcing the 
idea that pelagophytes might be more oligotrophic than suggested by Latasa et al. 849 (2010). On the other hand, dinoflagellates, with heterotrophic, autotrophic and 
872 phytoplankton usually more susceptible to heavy microzooplankton grazing

(Hunter-Cevera et al., 2020; Taylor and Landry, 2018).

The relationships between nutrient availability and relative group abundance found in this work reveal significant exceptions to the concept that small cells present advantages in low nutrient environments because of their high surface to volume ratio, while large cells outcompete small cells when nutrients are non-limiting. Diatoms and green algae are abundant in coastal waters (Not et al., 2005, 2004; Sarthou et al., 2005) where mixing and high nutrients are more common than in the open ocean. It is striking that these two groups, which comprise the largest and smallest eukaryotic phytoplankton, share the same ecological conditions of nutrients and turbulence. Factors other than size must play a role. Specific diatom advantages are a grazing-protective cell frustule (Mitchell et al., 2013), efficient nutrient assimilation (Olofsson et al., 2019) and the possession of cell vacuoles, which is helpful in fluctuating nutrient conditions (Stolte and Riegman, 1996; Tozzi et al., 2004). On the other hand, the high contribution of green algae under high nutrient concentrations could be due to a diminishing grazing pressure associated to the winter deepening of the mixed layer and subsequent decrease in the preypredator encounter rate. This decrease has been proposed for the previous and early conditions of the spring bloom (Behrenfeld, 2010). Moreover, green algae should also have some additional physiological advantage under these conditions that would favor them over other similarly sized groups such as pelagophytes. Autotrophic dinoflagellates and Prochlorococcus also seem to share the same environmental preferences for low nutrients and strong stratification despite their huge difference in size. The vertical migration capabilities of large dinoflagellates to 
obtain nutrients in deeper waters likely contributes to their success under oligotrophic conditions (Hall and Paerl, 2011; Ji and Franks, 2007). As mentioned above, dinoflagellates do not dominate under turbulent conditions while their mixotrophic forms are often abundant during stratification (Stoecker et al., 2017). Finally, cryptophytes and Synechococcus appear under similar environmental conditions despite their considerable size differences, although our results showed that a considerable portion of the cryptophyte assemblages were constituted by small cells (Fig. 7).

As a general pattern, a high biomass contribution of small cells occurs under low nutrients, and that of large cells under high nutrient conditions. However, this widespread assumption is far from being fulfilled when life-cycles and ecological strategies are contemplated and the contribution of individual groups to the total biomass are considered. Our study focused on three distinct periods of the annual cycle in the NW Mediterranean illustrates that departures from this general pattern can be captured by combining analytical tools currently available for the study of phytoplankton communities. The wide range of physical and chemical conditions also allowed us to unravel the preferences of the different groups in relation to depth and nutrients. This information, which should be refined with additional data, can be used to identify the direction of changes in phytoplankton communities in relation to possible alterations of physical and nutrient conditions under the climate change scenario. 
921 We thank the captain and crew of R/V Sarmiento de Gamboa and the Marine

922 Technology Unit (UTM) for their co-operation and support during the cruises. We

923 thank Carmen Cabeza and Felipe González for their help with HPLC pigment and

924 microscopy analyses, and Alejandro Isla for his help with figure preparation and data 925 processing. The thoughtful comments of two anonymous reviewers helped to 926 improve the manuscript.

\section{Funding}

This work was funded by Spanish Government, Ministerio de Ciencia e Innovación (project FAMOSO, grant CTM2008-06261-C03/MAR). AGR was also supported by the Generalitat de Catalunya (Grup de Recerca 2061).

\section{REFERENCES}

Agawin, N.S.R., Duarte, C.M., Agustí, S., 1998. Growth and abundance of Synechococcus sp. in a Mediterranean Bay: Seasonality and relationship with temperature. Mar. Ecol. Prog. Ser. 170, 45-53.

https://doi.org/10.3354/meps170045

Anderson, C.R., Siegel, D.A., Brzezinski, M. A., Guillocheau, N., 2008. Controls on temporal patterns in phytoplankton community structure in the Santa Barbara Channel, California. J. Geophys. Res. 113, C04038. https://doi.org/10.1029/2007JC004321

Araujo, M.L.V., Mendes, C.R.B., Tavano, V.M., Garcia, C.A.E., Baringer, M.O.N., 2017. Contrasting patterns of phytoplankton pigments and chemotaxonomic 
Arin, L., Guillén, J., Segura-Noguera, M., Estrada, M., 2013. Open sea hydrographic forcing of nutrient and phytoplankton dynamics in a Mediterranean coastal ecosystem. Estuar. Coast. Shelf Sci. 133, 1-13.

https://doi.org/10.1016/j.ecss.2013.08.018

Aytan, U., Feyzioglu, A.M., Valente, A., Agirbas, E., Fileman, E.S., 2018. Microbial plankton communities in the coastal southeastern Black Sea: biomass, composition and trophic interactions. Oceanologia 60, 139-152. https://doi.org/10.1016/j.oceano.2017.09.002

Barlow, R.G., Mantoura, R.F.C., Cummings, D.G., Fileman, T.W., 1997. Pigment chemotaxonomic distributions of phytoplankton during summer in the western Mediterranean. Deep Sea Res. II 44, 833-850. https://doi.org/10.1016/S09670645(96)00089-6

Barlow, R.G., Mantoura, R.F.C.C., Gough, M.A., Fileman, T.W., 1993. Pigment signatures of the phytoplankton composition in the northeastern Atlantic during the 1990 spring bloom. Deep. Res. II 40, 459-477. https://doi.org/10.1016/09670645(93)90027-K

Beardall, J., 2008. Blooms of Synechococcus. An analysis of the problem worldwide and possible causative factors in relation to nuisance blooms in the Gippsland Lakes. https://doi.org/https://www.loveourlakes.net.au/wpcontent/uploads/2015/05/blooms-of-Synechococcus.pdf

Behrenfeld, M.J., 2010. Abandoning Sverdrup's critical depth hypothesis on phytoplankton blooms. Ecology 91, 977-989. https://doi.org/10.1890/09-1207.1

970 Bidigare, R.R., Latasa, M., Johnson, Z., Barber, R.T., Trees, C.C., Balch, W.M., 
1996. Observations of a Synechococcus-dominated cyclonic eddy in openoceanic waters of the Arabian Sea. Ocean Opt. XIII 2963, 260-265. https://doi.org/10.1117/12.266452

Binder, B.B.J., Chisholm, S.S.W., Olson, R.J.R., Frankel, S.L., Worden, A.Z., 1996. Dynamics of picophytoplankton, ultraphytoplankton and bacteria in the central equatorial Pacific. Deep. Res. II 43, 907-931. https://doi.org/10.1016/09670645(96)00023-9

Bolaños, L.M., Karp-Boss, L., Choi, C.J., Worden, A.Z., Graff, J.R., Haëntjens, N., Chase, A.P., Della Penna, A., Gaube, P., Morison, F., Menden-Deuer, S., Westberry, T.K., O’Malley, R.T., Boss, E., Behrenfeld, M.J., Giovannoni, S.J., 2020. Small phytoplankton dominate western North Atlantic biomass. ISME J. 14, 1663-1674. https://doi.org/10.1038/s41396-020-0636-0

Bosc, E., Bricaud, A., Antoine, D., 2004. Seasonal and interannual variability in algal biomass and primary production in the Mediterranean Sea, as derived from 4 years of SeaWiFS observations. Glob. Biogeochem. Cycles 18, GB1005. https://doi.org/10.1029/2003GB002034

Bracher, A., Xi, H., Dinter, T., Mangin, A., Strass, V., von Appen, W.J., Wiegmann, S., 2020. High Resolution Water Column Phytoplankton Composition Across the Atlantic Ocean From Ship-Towed Vertical Undulating Radiometry. Front. Mar. Sci. 7, 1-22. https://doi.org/10.3389/fmars.2020.00235

Brewin, R.J.W.W., Ciavatta, S., Sathyendranath, S., Jackson, T., Tilstone, G., Curran, K., Airs, R.L., Cummings, D., Brotas, V., Organelli, E., Dall'Olmo, G., Raitsos, D.E., 2017. Uncertainty in ocean-color estimates of chlorophyll for phytoplankton groups. Front. Mar. Sci. 4, 104. https://doi.org/10.3389/fmars.2017.00104 
Bustillos-Guzman, J., Claustre, H., Marty, J.C., 1995. Specific phytoplankton signatures and their relationship to hydrographic conditions in the coastal northwestern Mediterranean Sea. Mar. Ecol. Prog. Ser. 124, 247-258. https://doi.org/10.3354/meps124247

Cabello, A.M., Latasa, M., Forn, I., Morán, X.A.G., Massana, R., 2016. Vertical distribution of major photosynthetic picoeukaryotic groups in stratified marine waters. Environ. Microbiol. 18, 1578-1590. https://doi.org/10.1111/14622920.13285

Calvo-Díaz, A., Morán, X.A.G., 2006. Seasonal dynamics of picoplankton in shelf waters of the southern Bay of Biscay. Aquat. Microb. Ecol. 42, 159-174. https://doi.org/10.3354/ame042159

Calvo-Díaz, A., Morán, X.A.G., Suárez, L.Á., 2008. Seasonality of picophytoplankton chlorophyll a and biomass in the central Cantabrian Sea, southern Bay of Biscay. J. Mar. Syst. 72, 271-281. https://doi.org/10.1016/j.jmarsys.2007.03.008

Caron, D.A., 1983. Technique for enumeration of heterotrophic and phototrophic nanoplankton, using epifluorescence microscopy, and comparison with other procedures. Appl. Environ. Microbiol. 46, 491-498.

https://doi.org/10.1128/aem.46.2.491-498.1983

Casey, J.R., Aucan, J.P., Goldberg, S.R., Lomas, M.W., 2013. Changes in partitioning of carbon amongst photosynthetic pico- and nano-plankton groups in the Sargasso Sea in response to changes in the North Atlantic Oscillation. Deep. Res. II 93, 58-70. https://doi.org/10.1016/j.dsr2.2013.02.002

Cermeño, P., Lee, J.B., Wyman, K., Schofield, O., Falkowski, P.G., 2011. Competitive dynamics in two species of marine phytoplankton under nonequilibrium conditions. Mar. Ecol. Prog. Ser. 429, 19-28. 
Chase, A.P., Kramer, S.J., Haëntjens, N., Boss, E.S., Karp-Boss, L., Edmondson, M., Graff, J.R., 2020. Evaluation of diagnostic pigments to estimate phytoplankton size classes. Limnol. Oceanogr. Methods 18, 570-584. https://doi.org/10.1002/lom3.10385

Christaki, U., Van Wambeke, F., Dolan, J.R., 1999. Nanoflagellates (mixotrophs, heterotrophs and autotrophs) in the oligotrophic eastern Mediterranean: standing stocks, bacterivory and relationships with bacterial production. Mar. Ecol. Prog. Ser. 181, 297-307. https://doi.org/10.3354/meps181297

Cullen, J.J., Franks, P.J.S., Karl, D.M., Longhurst, A.R., 2002. Physical influences on marine ecosystem dynamics, in: Robinson, A.R., McCarthy, J.J., Rothschild, B.J. (Eds.), The Sea. John Wiley \& Sons, New York, pp. 297-336.

D'Ortenzio, F., Ribera d'Alcalà, M., 2009. On the trophic regimes of the Mediterranean Sea : a satellite analysis. Biogeosciences 6, 139-148. https://doi.org/10.5194/bg-6-139-2009

Delgado, M., Latasa, M., Estrada, M., 1992. Variability in the size fractionated distribution of the phytoplankton across the Catalan front of the north-west Mediterranean. J. Plankton Res. 14, 753-771.

Denis, M., Thyssen, M., Martin, V., Manca, B., Vidussi, F., 2010. Ultraphytoplankton basin-scale distribution in the eastern Mediterranean Sea in winter: link to hydrodynamism and nutrients. Biogeosciences 7, 2227-2244. https://doi.org/10.5194/bg-7-2227-2010

Di Cicco, A., Sammartino, M., Marullo, S., Santoleri, R., 2017. Regional empirical algorithms for an improved identification of phytoplankton functional types and size classes in the Mediterranean sea using satellite data. Front. Mar. Sci. 4, 1- 
Edwards, K.F., 2019. Mixotrophy in nanoflagellates across environmental gradients in the ocean. Proc. Natl. Acad. Sci. 116, 6211-6220.

https://doi.org/10.1073/pnas.1814860116

Estrada, M., 1991. Phytoplankton assemblages across a NW Mediterranean front: Changes from winter mixing to spring stratification. Oecologia Aquat. 10, 157185.

Estrada, M., 1985. Deep phytoplankton and chlorophyll maxima in the western Mediterranean. Mediterr. Mar. Ecosyst. 247-277. https://doi.org/10.1007/978-14899-2248-9_12

Estrada, M., Latasa, M., Emelianov, M., Gutiérrez-Rodríguez, A., Fernández-Castro, B., Isern-Fontanet, J., Mouriño-Carballido, B., Salat, J., Vidal, M., 2014.

Seasonal and mesoscale variability of primary production in the deep wintermixing region of the NW Mediterranean. Deep. Res. I 94, 45-61. https://doi.org/10.1016/j.dsr.2014.08.003

Estrada, M., Varela, R.A., Salat, J., Cruzado, A., Arias, E., 1999. Spatio-temporal variability of the winter phytoplankton distribution across the Catalan and North Balearic fronts (NW Mediterranean). J. Plankton Res. 21, 1-20. https://doi.org/10.1093/plankt/21.1.1

Flombaum, P., Wang, W.L., Primeau, F.W., Martiny, A.C., 2020. Global picophytoplankton niche partitioning predicts overall positive response to ocean warming. Nat. Geosci. 13, 116-120. https://doi.org/10.1038/s41561-019-0524-2

Gomes, A., Gasol, J.M., Estrada, M., Franco-Vidal, L., Díaz-Pérez, L., Ferrera, I., Morán, X.A.G., 2015. Heterotrophic bacterial responses to the winter-spring phytoplankton bloom in open waters of the NW Mediterranean. Deep. Res. Part I 
Grasshoff, K., Kremling, K., Ehrhardt, M., 2007. Methods of Seawater Analysis:

Third, Completely Revised and Extended Edition. Wiley.

https://doi.org/10.1002/9783527613984

Gutiérrez-Rodríguez, A., Latasa, M., Scharek, R., Massana, R.R., Vila, G., Gasol, J.M., 2011. Growth and grazing rate dynamics of major phytoplankton groups in an oligotrophic coastal site. Estuar. Coast. Shelf Sci. 95, 77-87.

https://doi.org/10.1016/j.ecss.2011.08.008

Hall, N.S., Paerl, H.W., 2011. Vertical migration patterns of phytoflagellates in relation to light and nutrient availability in a shallow microtidal estuary. Mar. Ecol. Prog. Ser. 425, 1-19. https://doi.org/10.3354/meps09031

HELCOM, 2017. Monitoring of phytoplankton species composition, abundance and biomass. https://doi.org/https://helcom.fi/media/publications/Guidelines-formonitoring-phytoplankton-species-composition-abundance-and-biomass.pdf

Hillebrand, H., Dürselen, C.D., Kirschtel, D., Pollingher, U., Zohary, T., 1999.

Biovolume calculation for pelagic and benthic microalgae. J. Phycol. 35, 403424. https://doi.org/10.1046/j.1529-8817.1999.3520403.x

Hrycik, A.R., Shambaugh, A., Stockwell, J.D., 2019. Comparison of FlowCAM and microscope biovolume measurements for a diverse freshwater phytoplankton community. J. Plankton Res. 41, 849-864. https://doi.org/10.1093/plankt/fbz056 Hunter-Cevera, K.R., Neubert, M.G., Olson, R.J., Shalapyonok, A., Solow, A.R., Sosik, H.M., 2020. Seasons of Syn. Limnol. Oceanogr. 65, 1085-1102. https://doi.org/10.1002//no.11374

Hunter-Cevera, K.R., Post, A.F., Peacock, E.E., Sosik, H.M., 2016. Diversity of Synechococcus at the Martha's Vineyard Coastal Observatory: Insights from 
Isla, A., Scharek, R., Latasa, M., 2015. Zooplankton diel vertical migration and contribution to deep active carbon flux in the NW Mediterranean. J. Mar. Syst. 143, 86-97. https://doi.org/10.1016/j.jmarsys.2014.10.017

Jeong, H.J., du Yoo, Y., Kim, J.S., Seong, K.A., Kang, N.S., Kim, T.H., 2010. Growth, feeding and ecological roles of the mixotrophic and heterotrophic dinoflagellates in marine planktonic food webs. Ocean Sci. J. 45, 65-91.

https://doi.org/10.1007/s12601-010-0007-2

Ji, R., Franks, P.J.S., 2007. Vertical migration of dinoflagellates: Model analysis of strategies, growth, and vertical distribution patterns. Mar. Ecol. Prog. Ser. 344, 49-61. https://doi.org/10.3354/meps06952

Johnson, M.D., Stoecker, D.K., Marshall, H.G., 2013. Seasonal dynamics of Mesodinium rubrum in Chesapeake Bay. J. Plankton Res. 35, 877-893. https://doi.org/10.1093/plankt/fbt028

Johnson, Z.I., Zinser, E.R., Coe, A., McNulty, N.P., Woodward, E.M.S., Chisholm, S.W., 2006. Niche partitioning among Prochlorococcus ecotypes along oceanscale environmental gradients. Science $311,1737-1740$.

https://doi.org/10.1126/science.1118052

Kramer, S.J., Siegel, D.A., 2019. How can phytoplankton pigments be best used to characterize surface ocean phytoplankton groups for ocean color remote sensing algorithms? J. Geophys. Res. Ocean. 124, 7557-7574. https://doi.org/10.1029/2019JC015604

Kuipers, B.R., Witte, H.J., 2000. Prochlorophytes as secondary prey for heterotrophic nanoflagellates in the deep chlorophyll maximum layer of the (sub)tropical North 
Latasa, M., 2007. Improving estimations of phytoplankton class abundances using CHEMTAX. Mar. Ecol. Prog. Ser. 329, 13-21.

https://doi.org/10.3354/meps329013

Latasa, M., Cabello, A.M., Morán, X.A.G., Massana, R., Scharek, R., 2017.

Distribution of phytoplankton groups within the deep chlorophyll maximum.

Limnol. Oceanogr. 62, 665-685. https://doi.org/10.1002//no.10452

Latasa, M., Estrada, M., Delgado, M., 1992. Plankton-pigment relationships in the Northwestern Mediterranean during stratification. Mar. Ecol. Prog. Ser. 88, 6173.

Latasa, M., Scharek, R., Vidal, M., Vila-Reixach, G., Gutiérrez-Rodríguez, A., Emelianov, M., Gasol, J.M., 2010. Preferences of phytoplankton groups for waters of different trophic status in the northwestern Mediterranean Sea. Mar. Ecol. Prog. Ser. 407, 27-42. https://doi.org/10.3354/meps08559

Leblanc, K., Quéguiner, B., Diaz, F., Cornet, V., Michel-Rodriguez, M., Durrieu De Madron, X., Bowler, C., Malviya, S., Thyssen, M., Grégori, G., Rembauville, M., Grosso, O., Poulain, J., De Vargas, C., Pujo-Pay, M., Conan, P., 2018.

Nanoplanktonic diatoms are globally overlooked but play a role in spring blooms and carbon export. Nat. Commun. 9, 1-12. https://doi.org/10.1038/s41467-01803376-9

Leroux, R., Gregori, G., Leblanc, K., Carlotti, F., Thyssen, M., Dugenne, M., PujoPay, M., Conan, P., Jouandet, M.P., Bhairy, N., Berline, L., 2018. Combining laser diffraction, flow cytometry and optical microscopy to characterize a nanophytoplankton bloom in the Northwestern Mediterranean. Prog. Oceanogr. 163, 248-259. https://doi.org/10.1016/j.pocean.2017.10.010 
Lévy, M., Mémery, L., Madec, G., 1999. The onset of the Spring Bloom in the MEDOC area: mesoscale spatial variability. Deep. Res. I 46, 1137-1160. https://doi.org/10.1016/S0967-0637(98)00105-8

Malmstrom, R.R., Coe, A., Kettler, G.C., Martiny, A.C., Frias-Lopez, J., Zinser, E.R., Chisholm, S.W., 2010. Temporal dynamics of Prochlorococcus ecotypes in the Atlantic and pacific oceans. ISME J. 4, 1252-1264.

https://doi.org/10.1038/ismej.2010.60

Margalef, R., 1978. Life-forms of phytoplankton as survival alternatives in an unstable environment. Oceanol. Acta 1, 493-509.

Marty, J.C., Chiavérini, J., Pizay, M.D., Avril, B., 2002. Seasonal and interannual dynamics of nutrients and phytoplankton pigments in the western Mediterranean Sea at the DYFAMED time-series station (1991-1999). Deep. Res. II 49, 19651985. https://doi.org/10.1016/S0967-0645(02)00022-X

MEDOC Group, 1970. Observation of formation of deep water in the Mediterranean Sea, 1969. Nature 227, 1037-1040. https://doi.org/10.1038/2271037a0

Mena, C., Reglero, P., Hidalgo, M., Sintes, E., Santiago, R., Martín, M., Moyà, G., Balbín, R., 2019. Phytoplankton community structure is driven by stratification in the oligotrophic Mediterranean sea. Front. Microbiol. 10, 1698.

https://doi.org/10.3389/fmicb.2019.01698

Menden-Deuer, S., Lessard, E.J., 2000. Carbon to volume relationships for dinoflagellates, diatoms, and other protist plankton. Limnol. Oceanogr. 45, 569579. https://doi.org/10.4319/lo.2000.45.3.0569

Miranda-Alvarez, C., González-Silvera, A., Santamaría-del-Angel, E., López-

Calderón, J., Godínez, V.M., Sánchez-Velasco, L., Hernández-Walls, R., 2020.

Phytoplankton pigments and community structure in the northeastern tropical 
6

pacific using HPLC-CHEMTAX analysis. J. Oceanogr. 76, 91-108.

https://doi.org/10.1007/s10872-019-00528-3

Mitchell, J.G., Seuront, L., Doubell, M.J., Losic, D., Voelcker, N.H., Seymour, J., Lal, R., 2013. The role of diatom nanostructures in biasing diffusion to improve uptake in a patchy nutrient environment. PLoS One 8, e59548. https://doi.org/10.1371/journal.pone.0059548

Not, F., Latasa, M., Marie, D., Cariou, T., Vaulot, D., Simon, N., Curie, M., Teis-, P.G., 2004. A Single Species, Micromonas pusilla (Prasinophyceae), Dominates the Eukaryotic Picoplankton in the Western English Channel. Appl. Environ. Microbiol. 70, 4064-4072. https://doi.org/10.1128/AEM.70.7.4064

Not, F., Massana, R., Latasa, M., Marie, D., Colson, C., Eikrem, W., Pedrós-Alió, C., Vaulot, D., Simon, N., 2005. Late summer community composition and abundance of photosynthetic picoeukaryotes in Norwegian and Barents Seas. Limnol. Oceanogr. 50, 1677-1686. https://doi.org/10.4319/lo.2005.50.5.1677

Nunes, S., Latasa, M., Delgado, M., Emelianov, M., Simó, R., Estrada, M., 2019.

Phytoplankton community structure in contrasting ecosystems of the Southern Ocean: South Georgia, South Orkneys and western Antarctic Peninsula. Deep.

Res. I 151, 103059. https://doi.org/10.1016/j.dsr.2019.06.005

Nunes, S., Latasa, M., Gasol, J.M.J.M., Estrada, M., 2018. Seasonal and interannual variability of phytoplankton community structure in a Mediterranean coastal site. Mar. Ecol. Prog. Ser. 592, 57-75. https://doi.org/10.3354/meps12493

Olenina, I., Hajdu, S., Edler, L., Andersson, A., Wasmund, N., Busch, S., Göbel, J., Gromisz, S., Huseby, S., Huttunen, M., Jaanus, A., Kokkonen, P., Ledaine, I., Niemkiewicz, E., 2006. Biovolumes and Size-Classes of Phytoplankton in the Baltic Sea, HELCOM Balt. Sea Environ. Proc 106, 144pp. 
Olofsson, M., Robertson, E.K., Edler, L., Arneborg, L., Whitehouse, M.J., Ploug, H., 2019. Nitrate and ammonium fluxes to diatoms and dinoflagellates at a single cell level in mixed field communities in the sea. Sci. Rep. 9, 1-12. https://doi.org/10.1038/s41598-018-38059-4

Olson, R.J., Chisholm, S.W., Zettler, E.R., Armbrust, E.V., 1990. Pigments, size, and distributions of Synechococcus in the North Atlantic and Pacific Oceans. Limnol. Oceanogr. 35, 45-58. https://doi.org/10.4319//o.1990.35.1.0045

Otero-Ferrer, J.L., Cermeño, P., Bode, A., Fernández-Castro, B., Gasol, J.M., Morán, X.A.G., Marañon, E., Moreira-Coello, V., Varela, M.M., Villamaña, M., MouriñoCarballido, B., 2018. Factors controlling the community structure of picoplankton in contrasting marine environments. Biogeosciences 15, 6199-6220. https://doi.org/10.5194/bg-15-6199-2018

Partensky, F., Blanchot, J., Lantoine, F., Neveux, J., Marie, D., 1996. Vertical structure of picophytoplankton at different trophic sites of the tropical northeastern Atlantic Ocean. Deep. Res. I 43, 1191-1213. https://doi.org/10.1016/0967-0637(96)00056-8

Pittera, J., Humily, F., Thorel, M., Grulois, D., Garczarek, L., Six, C., 2014. Connecting thermal physiology and latitudinal niche partitioning in marine Synechococcus. ISME J. 8, 1221-1236. https://doi.org/10.1038/ismej.2013.228

Riegman, R., Kraay, G.W., 2001. Phytoplankton community structure derived from HPLC analysis of pigments in the Faroe-Shetland Channel during summer 1999: the distribution of taxonomic groups in relation to physical/chemical conditions in the photic zone. J. Plankton Res. 23, 191-205.

https://doi.org/10.1093/plankt/23.2.191 
Rodriguez, F., Varela, M., Zapata, M., 2002. Phytoplankton assemblages in the Gerlache and Bransfield Straits (Antarctic Peninsula) determined by light microscopy and CHEMTAX analysis of HPLC pigment data. Deep. Res. II 49, 723-747. https://doi.org/10.1016/S0967-0645(01)00121-7

Saito, M.A., Rocap, G., Moffett, J.W., 2005. Production of cobalt binding ligands in a Synechococcus feature at the Costa Rica upwelling dome. Limnol. Oceanogr. 50, 279-290. https://doi.org/10.4319/lo.2005.50.1.0279

Salat, J., Emelianov, M., Fraile, E., Latasa, M., 2013. After deep water formation: sinking and spreading or reorganising phase, including upwelling? Rapp. Comm. int. Mer Médit. 40, 175.

Salat, J., Puig, P., Latasa, M., 2010. Violent storms within the Sea: Dense water formation episodes in the NW Mediterranean. Adv. Geosci. 26, 53-59. https://doi.org/10.5194/adgeo-26-53-2010

Sarthou, G., Timmermans, K.R., Blain, S., Tréguer, P., 2005. Growth physiology and fate of diatoms in the ocean: a review. J. Sea Res. 53, 25-42. https://doi.org/10.1016/j.seares.2004.01.007

Scanlan, D.J., Ostrowski, M., Mazard, S., Dufresne, A., Garczarek, L., Hess, W.R., Post, A.F., Hagemann, M., Paulsen, I., Partensky, F., 2009. Ecological Genomics of Marine Picocyanobacteria. Microbiol. Mol. Biol. Rev. 73, 249-299. https://doi.org/10.1128/mmbr.00035-08

Scanlan, D.J., West, N.J., 2002. Molecular ecology of the marine cyanobacterial genera Prochlorococcus and Synechococcus. FEMS Microbiol. Ecol. 40, 1-12. https://doi.org/10.1016/S0168-6496(01)00217-3

Schlitzer, R., 2016. Ocean Data View, http://odv.awi.de.

Schoemann, V., Becquevort, S., Stefels, J., Rousseau, V., Lancelot, C., 2005. 
Phaeocystis blooms in the global ocean and their controlling mechanisms: a review. J. Sea Res. 53, 43-66. https://doi.org/10.1016/j.seares.2004.01.008

Schofield, O., Saba, G., Coleman, K., Carvalho, F., Couto, N., Ducklow, H., Finkel, Z., Irwin, A., Kahl, A., Miles, T., Montes-Hugo, M., Stammerjohn, S., Waite, N., 2017. Decadal variability in coastal phytoplankton community composition in a changing West Antarctic Peninsula. Deep. Res. I 124, 42-54. https://doi.org/10.1016/j.dsr.2017.04.014

Severin, T., Conan, P., Durrieu de Madron, X., Houpert, L., Oliver, M.J., Oriol, L., Caparros, J., Ghiglione, J.F., Pujo-Pay, M., 2014. Impact of open-ocean convection on nutrients, phytoplankton biomass and activity. Deep. Res. I 94, 62-71. https://doi.org/10.1016/j.dsr.2014.07.015

Severin, T., Kessouri, F., Rembauville, M., Sanchez-Perez, E.D., Oriol, L., Caparros, J., Pujo-Pay, M., Ghiglione, J.-F., D’Ortenzio, F., Taillandier, V., Mayot, N., Madron, X.D. De, Ulses, C., Estournel, C., Conan, P., 2017. Open-ocean convection process: A driver of the winter nutrient supply and the spring phytoplankton distribution in the Northwestern Mediterranean Sea. J. Geophys.

Res. Ocean. 122, 4587-4601. https://doi.org/10.1002/2016JC012664

Smayda, T.J., Reynolds, C.S., 2003. Strategies of marine dinoflagellate survival and some rules of assembly. J. Sea Res. 49, 95-106. https://doi.org/10.1016/S13851101(02)00219-8

Sommaruga, R., Hofer, J.S., Alonso-Sáez, L., Gasol, J.M., 2005. Differential sunlight sensitivity of picophytoplankton from surface Mediterranean coastal waters.

Appl. Environ. Microbiol. 71, 2154-2157. https://doi.org/10.1128/AEM.71.4.21542157.2005

Stoecker, D.K., Hansen, P.J., Caron, D.A., Mitra, A., 2017. Mixotrophy in the Marine 
Plankton. Ann. Rev. Mar. Sci. 9, 311-335. https://doi.org/10.1146/annurevmarine-010816-060617

Stolte, W., Riegman, R., 1996. A model approach for size-selective competition of marine phytoplankton for fluctuating nitrate and ammonium. J. Phycol. 32, 732740. https://doi.org/10.1111/j.0022-3646.1996.00732.x

Sun, J., Liu, D., 2003. Geometric models for calculating cell biovolume and surface area for phytoplankton. J. Plankton Res. 25, 1331-1346.

https://doi.org/10.1093/plankt/fbg096

Taylor, A.G., Landry, M.R., 2018. Phytoplankton biomass and size structure across trophic gradients in the southern California Current and adjacent ocean ecosystems. Mar. Ecol. Prog. Ser. 592, 1-17. https://doi.org/10.3354/meps12526

Tozzi, S., Schofield, O., Falkowski, P., 2004. Historical climate change and ocean turbulence as selective agents for two key phytoplankton functional groups. Mar. Ecol. Prog. Ser. 274, 123-132. https://doi.org/10.3354/meps274123

Uitz, J., Claustre, H., Morel, A., Hooker, S.B., 2006. Vertical distribution of phytoplankton communities in open ocean: An assessment based on surface chlorophyll. J. Geophys. Res. 111, C08005. https://doi.org/10.1029/2005JC003207

Utermöhl, H., 1958. Zur Vervollkommnung der quantitativen Phytoplankton-Methodik. SIL Commun. 1953-1996 9, 1-38. https://doi.org/10.1080/05384680.1958.11904091

Verity, P.G., Brussaard, C.P., Nejstgaard, J.C., van Leeuwe, M. A., Lancelot, C., Medlin, L.K., 2007. Current understanding of Phaeocystis ecology and biogeochemistry, and perspectives for future research. Biogeochemistry 83 , 
Vidussi, F., Claustre, H., Manca, B.B., Luchetta, A., Marty, J.C., 2001. Phytoplankton pigment distribution in relation to upper thermocline circulation in the eastern Mediterranean Sea during winter. J. Geophys. Res. 106, 939-956. https://doi.org/10.1038/nm0497-414

Vidussi, F., Marty, J.C., Chiavérini, J., Chiave, J., 2000. Phytoplankton pigment variations during the transition from spring bloom to oligotrophy in the northwestern Mediterranean Sea. Deep. Res. I 47, 423-445. https://doi.org/10.1016/S0967-0637(99)00097-7

von Dassow, P., Van Den Engh, G., Iglesias-Rodriguez, D., Gittins, J.R., 2012. Calcification state of coccolithophores can be assessed by light scatter depolarization measurements with flow cytometry. J. Plankt. Res. 34, 10111027. https://doi.org/10.1093/plankt/fbs061

Worden, A.Z., Nolan, J.K., Palenik, B., 2004. Assessing the dynamics and ecology of marine picophytoplankton: The importance of the eukaryotic component. Limnol. Oceanogr. 49, 168-179. https://doi.org/10.4319/lo.2004.49.1.0168

Yoo, Y. Du, Seong, K.A., Jeong, H.J., Yih, W., Rho, J.R., Nam, S.W., Kim, H.S., 2017. Mixotrophy in the marine red-tide cryptophyte Teleaulax amphioxeia and ingestion and grazing impact of cryptophytes on natural populations of bacteria in Korean coastal waters. Harmful Algae 68, 105-117. https://doi.org/10.1016/j.hal.2017.07.012

Zapata, M., Fraga, S., Rodríguez, F., Garrido, J.L., 2012. Pigment-based chloroplast types in dinoflagellates. Mar. Ecol. Prog. Ser. 465, 33-52. https://doi.org/10.3354/meps09879

Zapata, M., Rodríguez, F., Garrido, J.L., Rodriguez, F., 2000. Separation of 
1321 chlorophylls and carotenoids from marine phytoplankton: a new HPLC method

1

21322

4

6

71324

8

9

10

11

12

13

14

15

16

17

18

19

20

21

22

23

24

25

26

27

28

29

30

31

32

33

34

35

36

37

38

39

40

41

42

43

44

45

46

47

48

49

50

51

52

53

54

55

56

57

58

59

60

61

62

63

64

65

using a reversed phase $\mathrm{C} 8$ column and pyridine- containing mobile phases. Mar.

Ecol. Prog. Ser. 195, 29-45. https://doi.org/10.3354/meps195029 

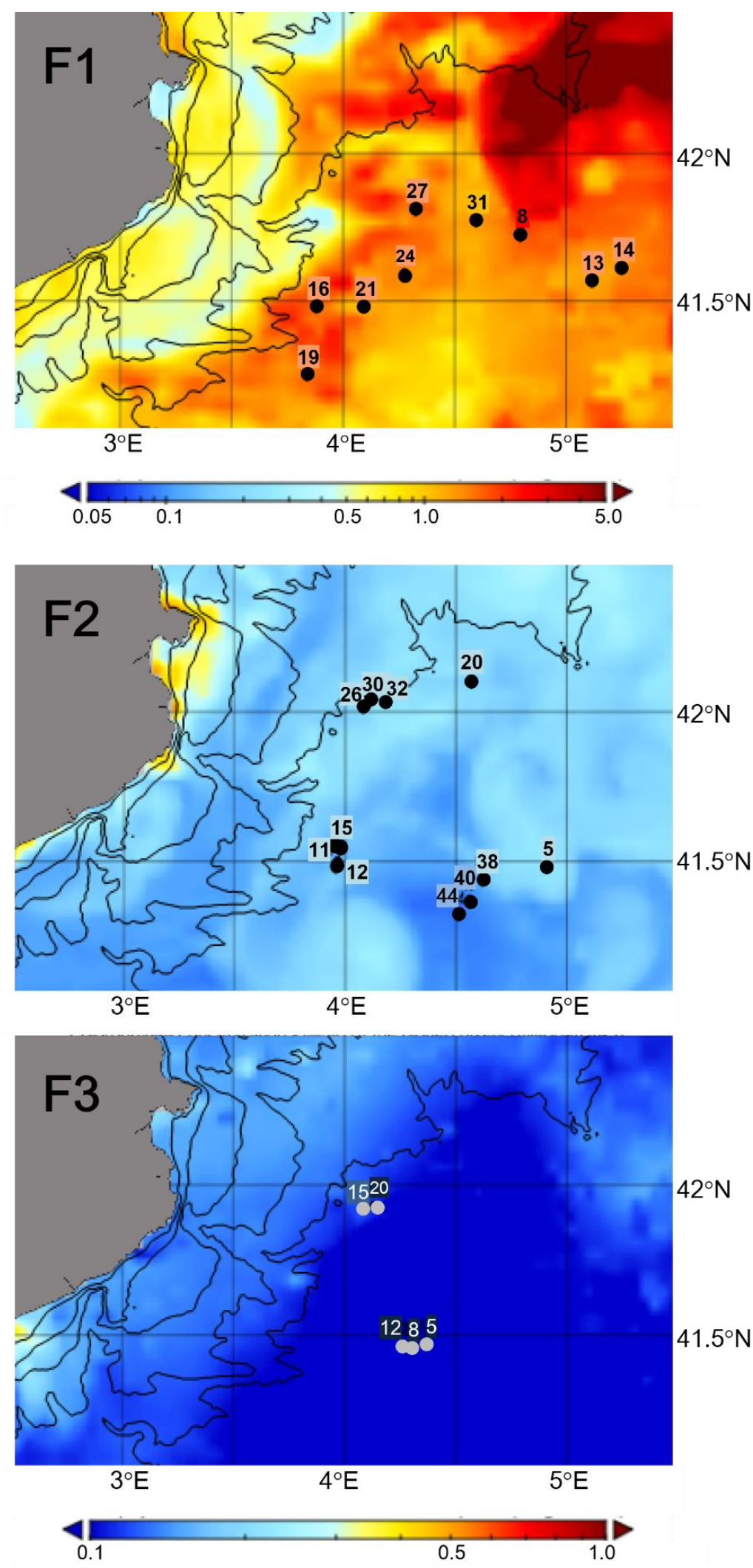

Fig. 1 

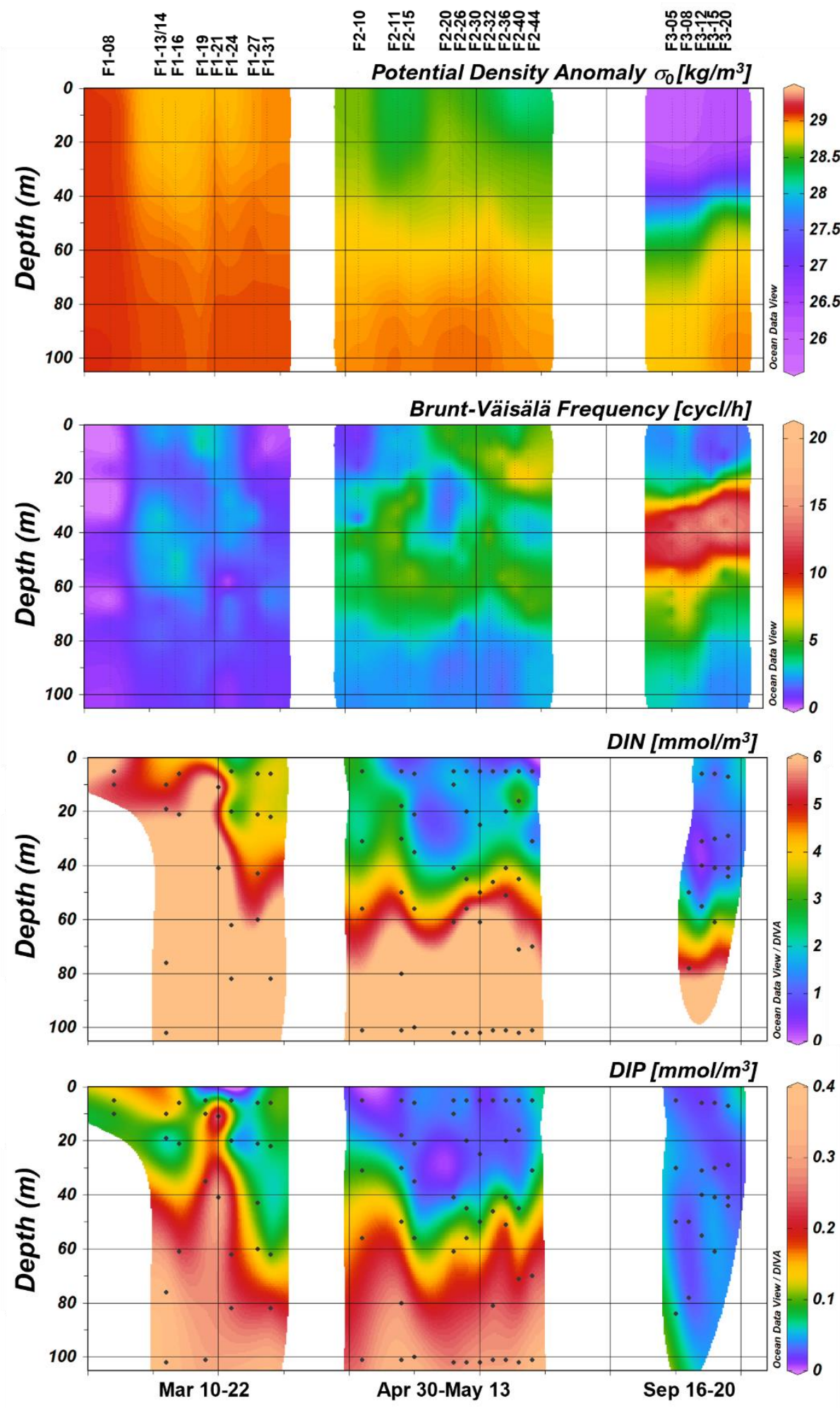

F1

F2

F3

Fig. 2 
Fig. 3
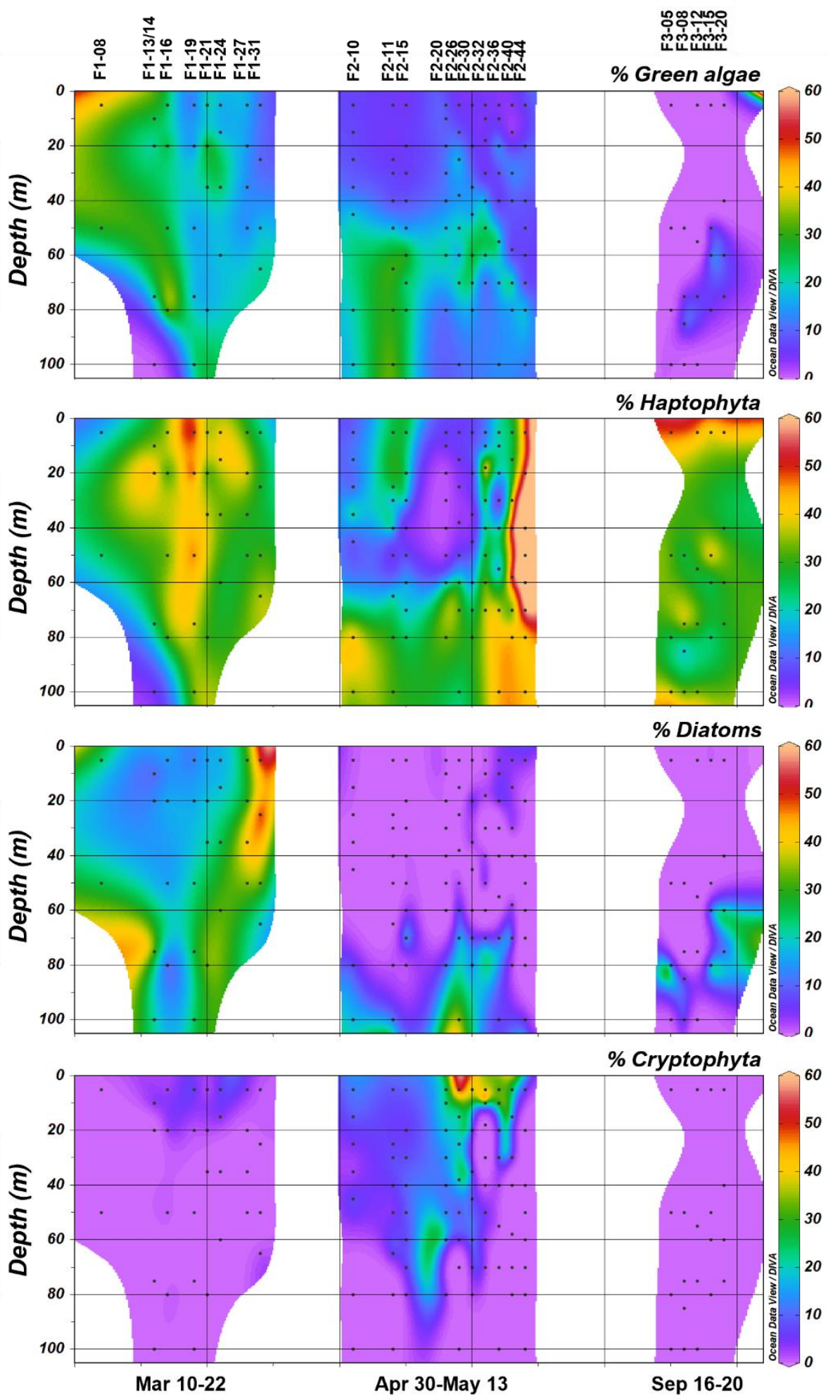

F1

F2

F3 

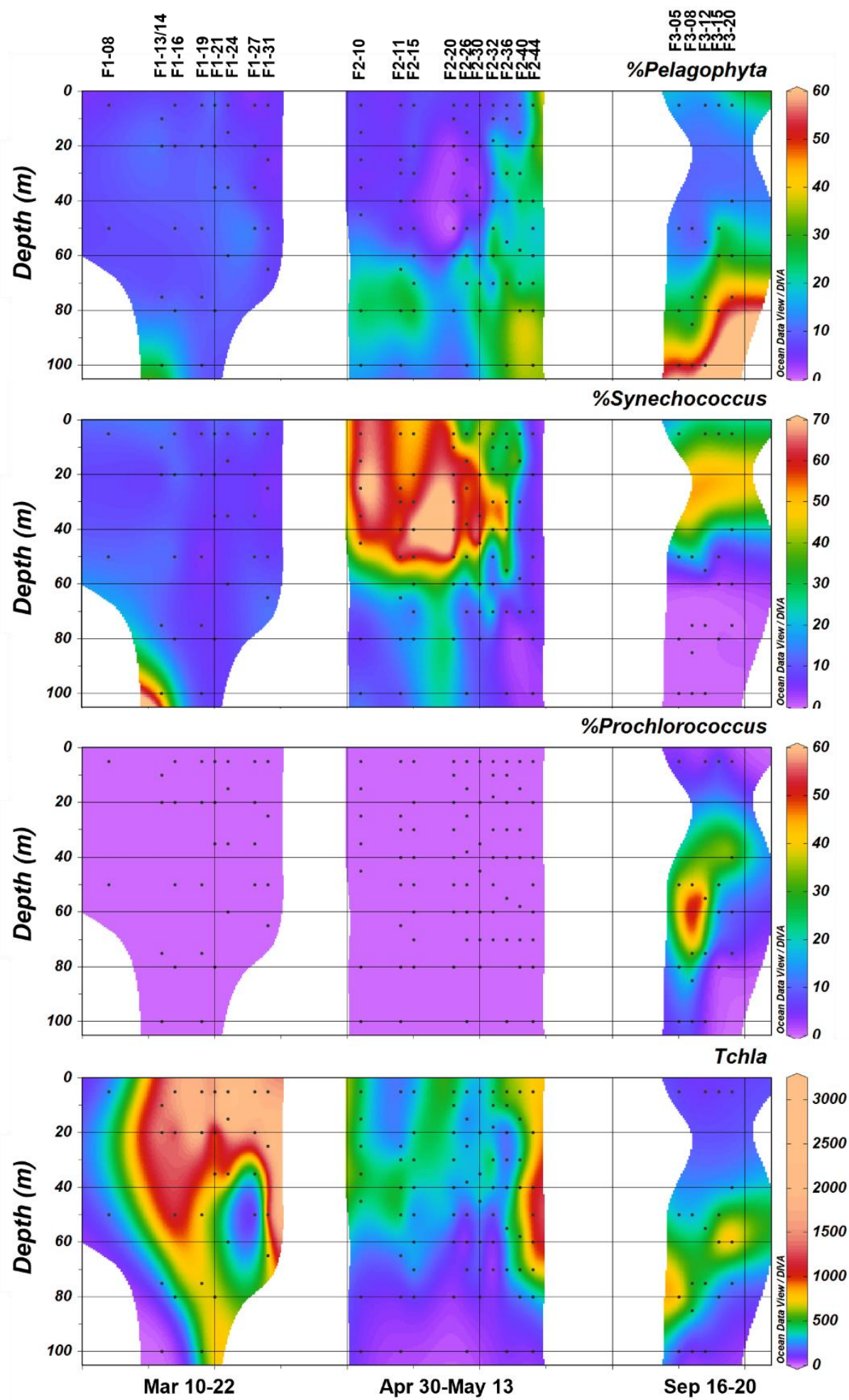

F1

F2

F3

Fig. 3 (cont.) 
Fig. 4
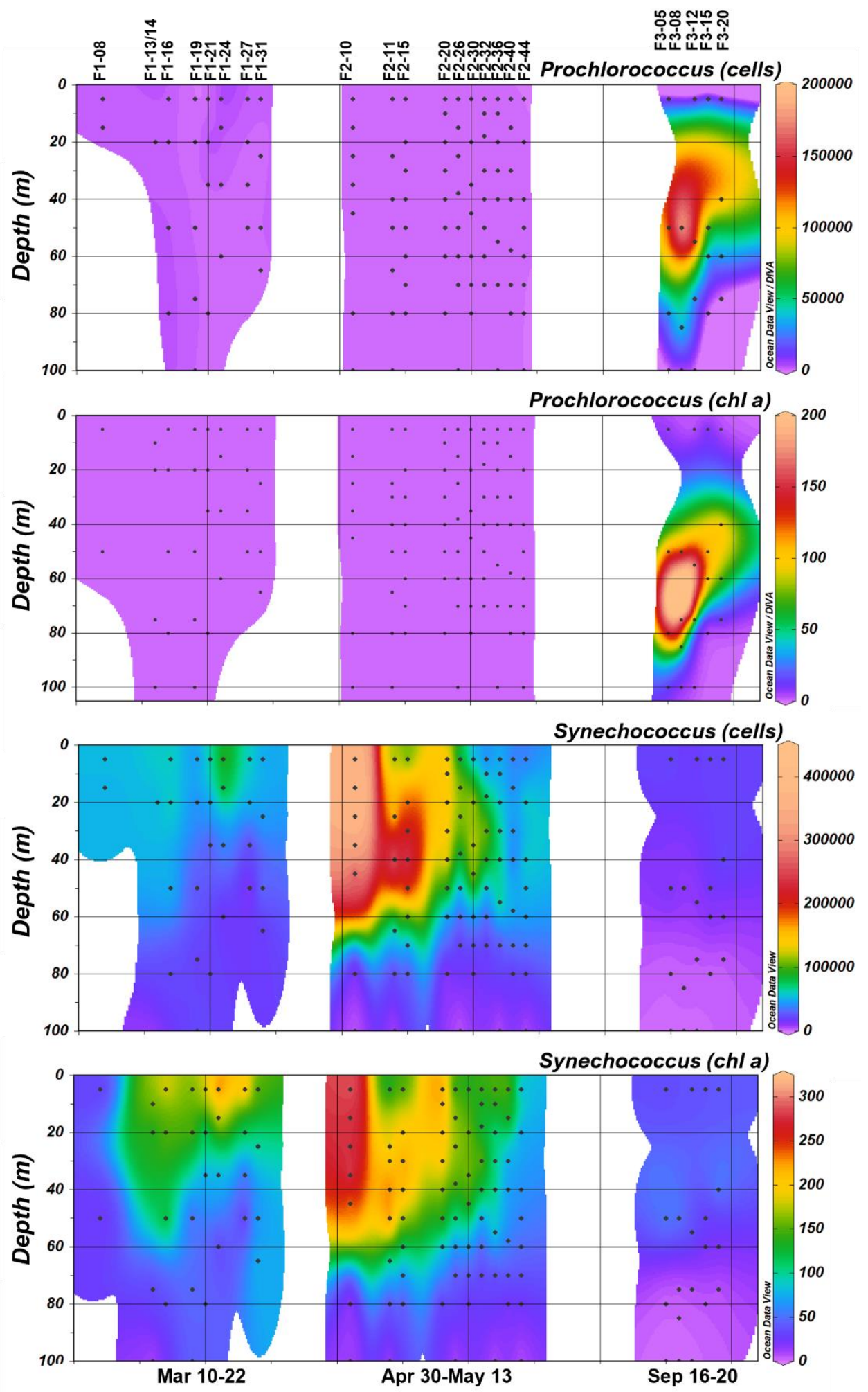

F1

F2

F3 
Fig. 4 (cont.)
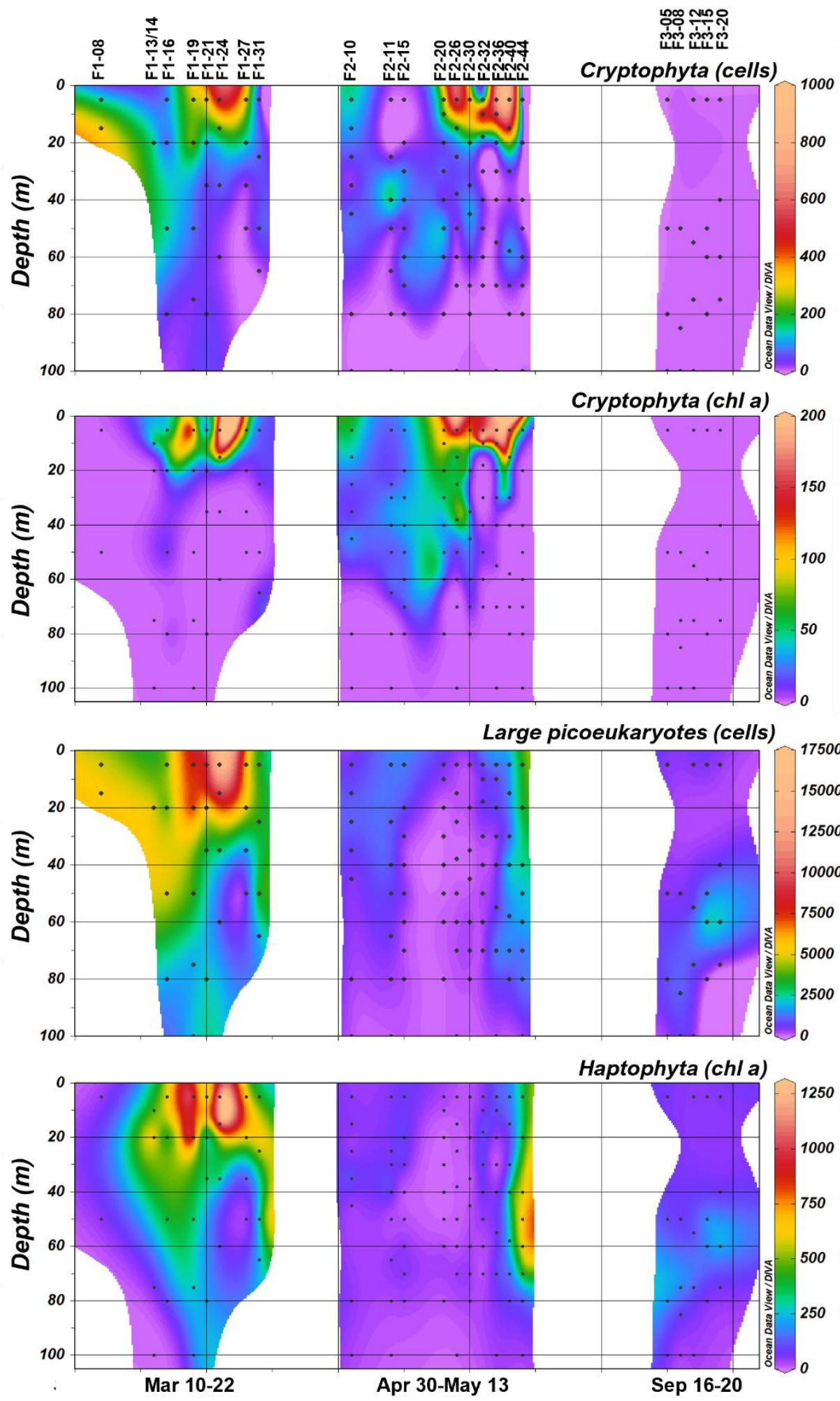

F1

F2

F3 

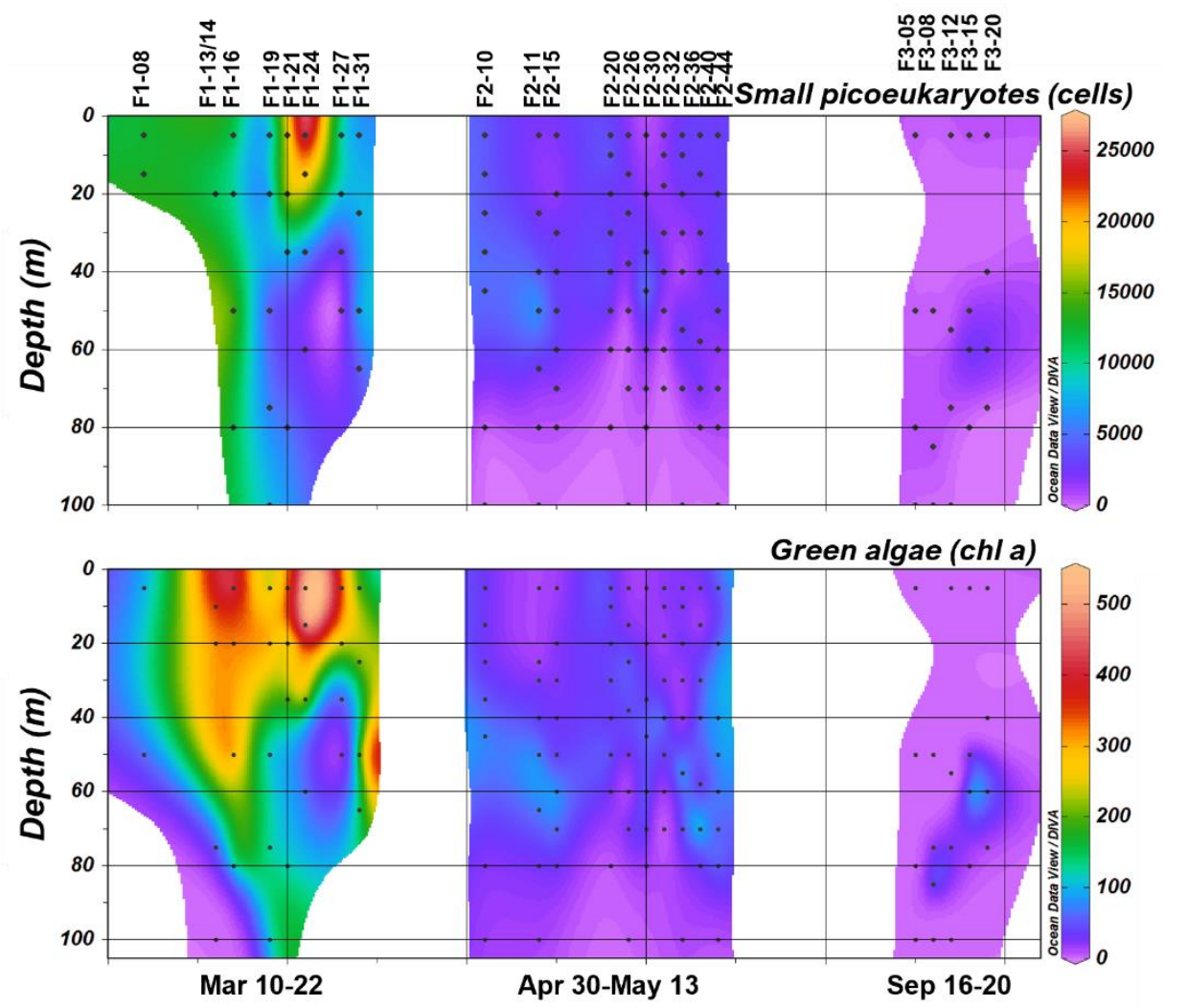

F1

F2

F3

Fig. 4 (cont.) 

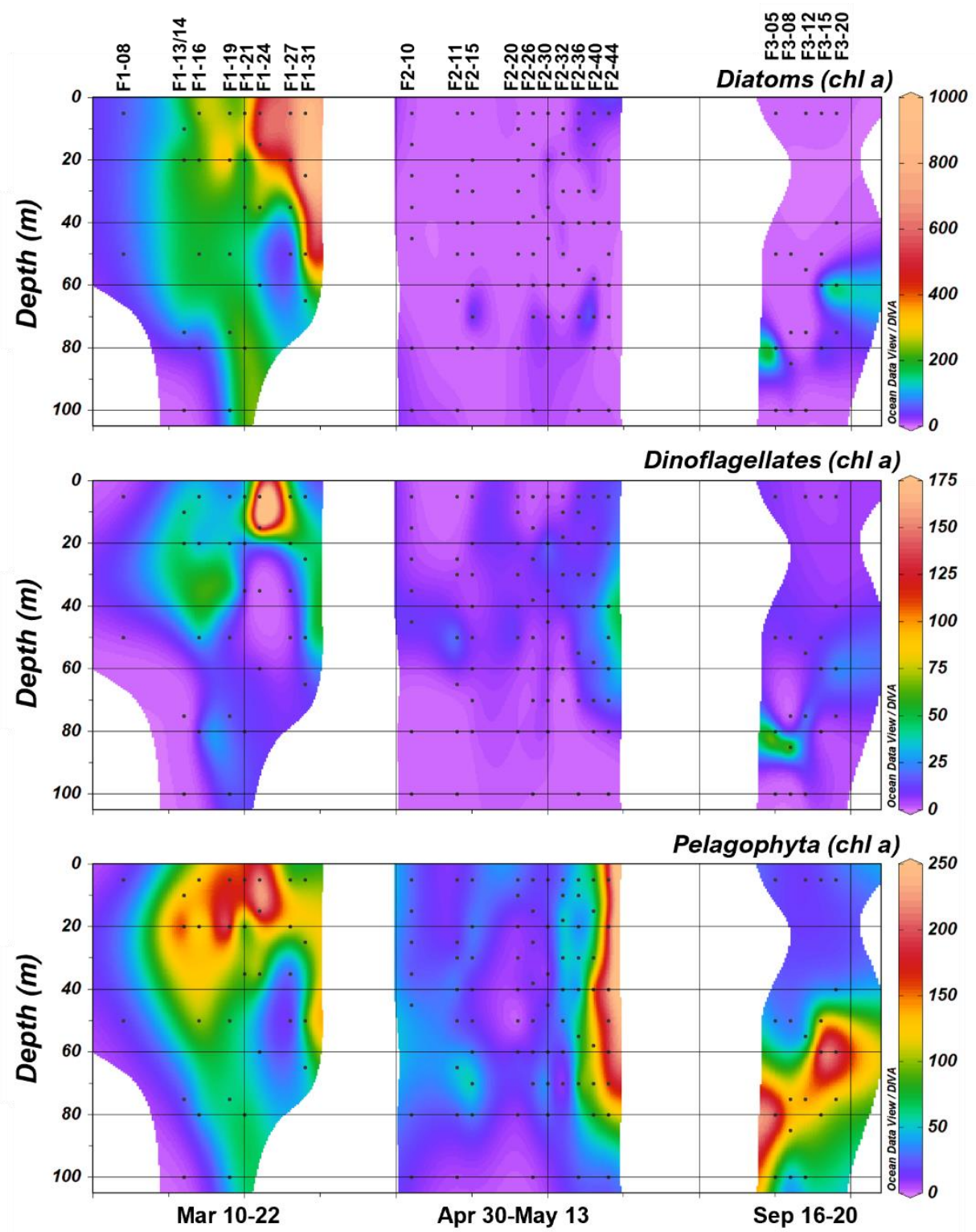

F1

F2

F3

Fig. 4 (cont.) 

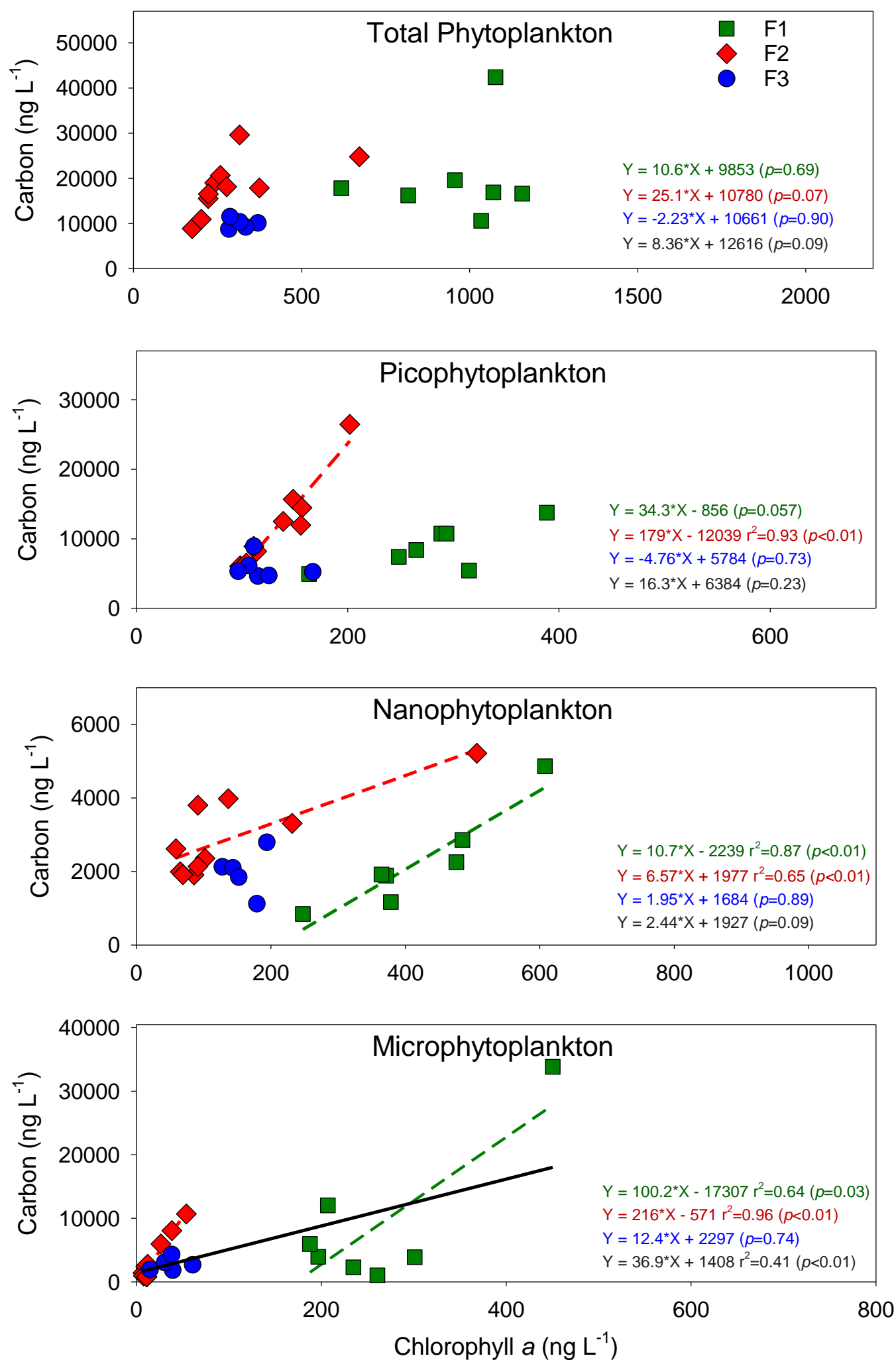

Fig. 5 


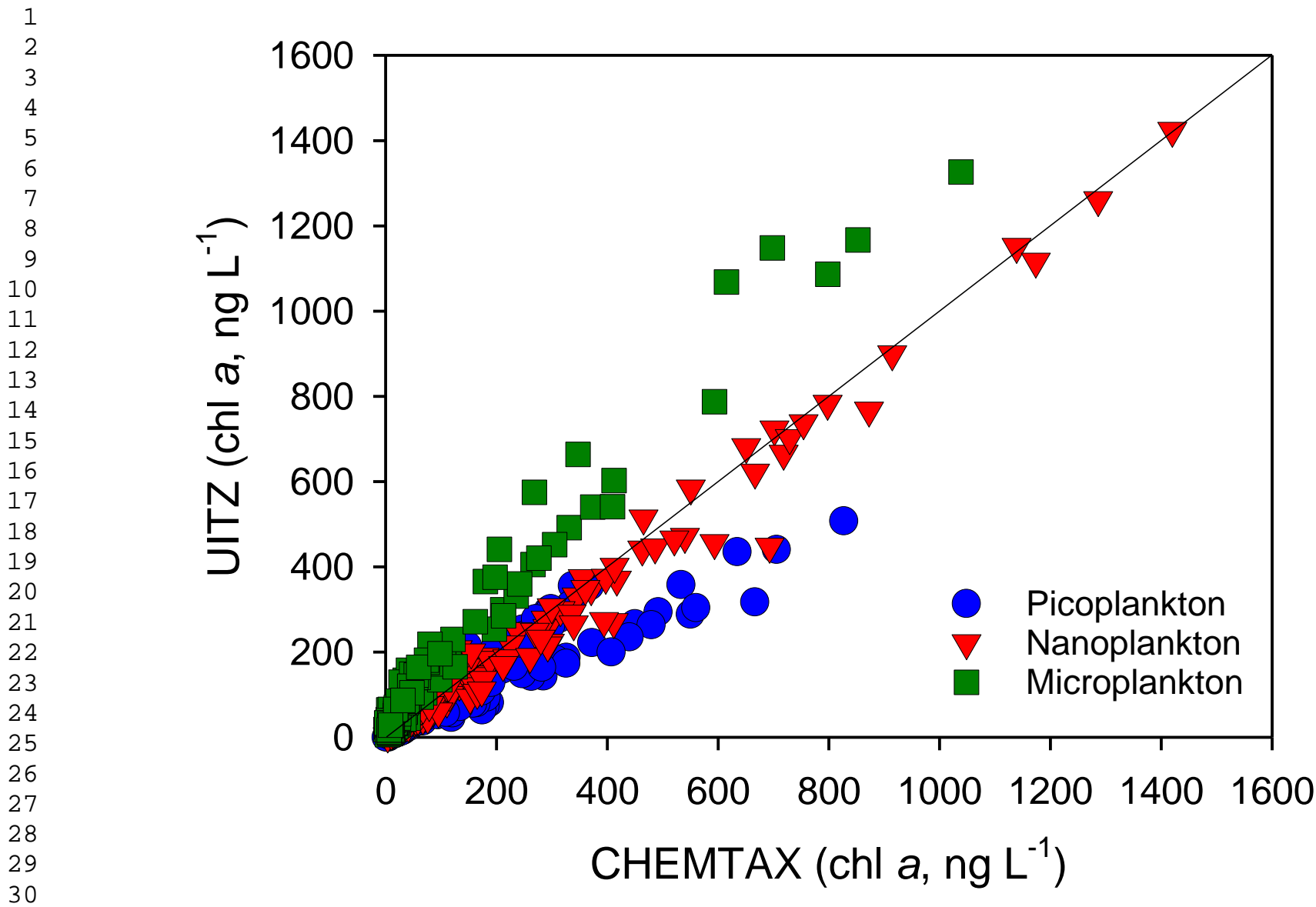

Fig. 6 

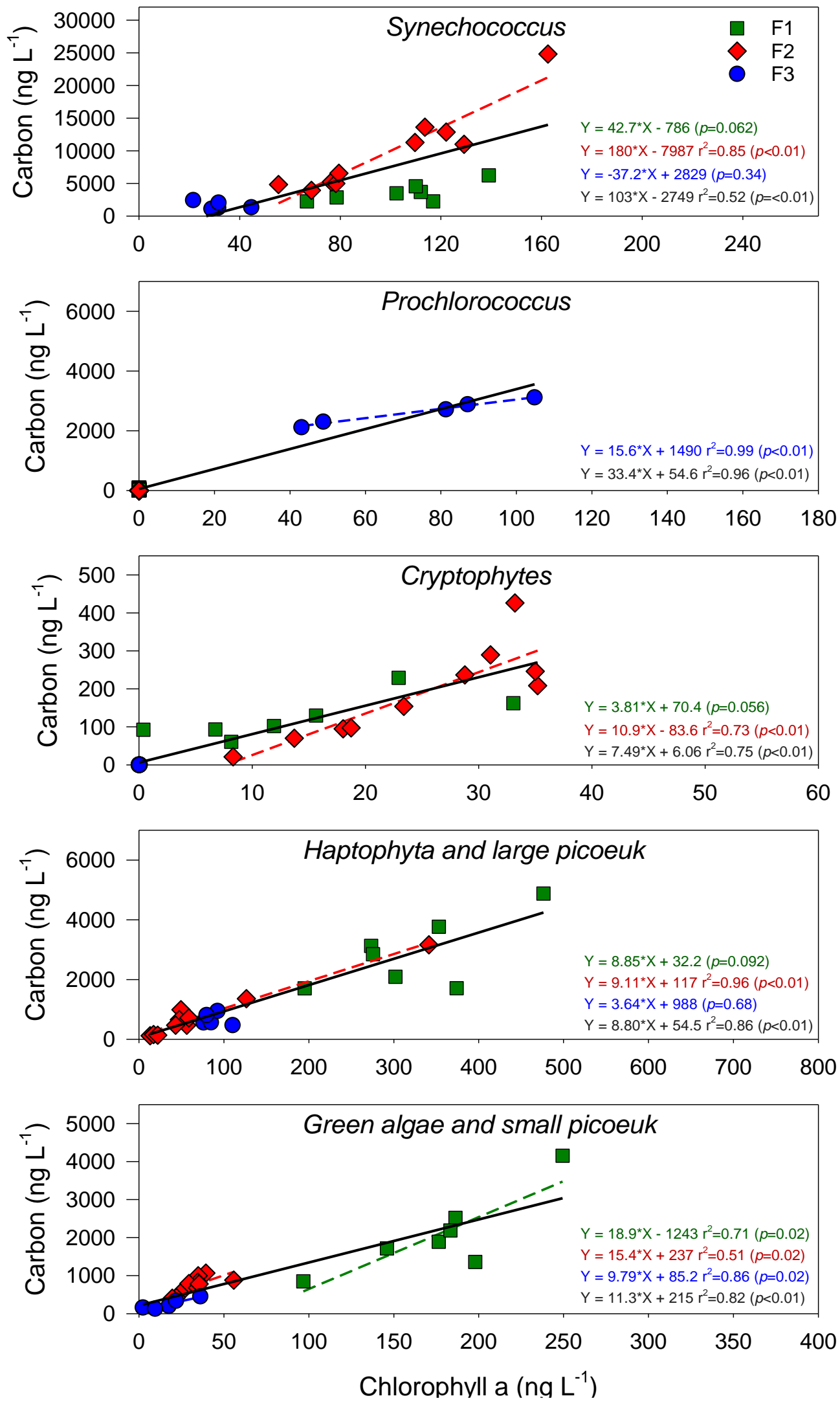

Fig. 7 

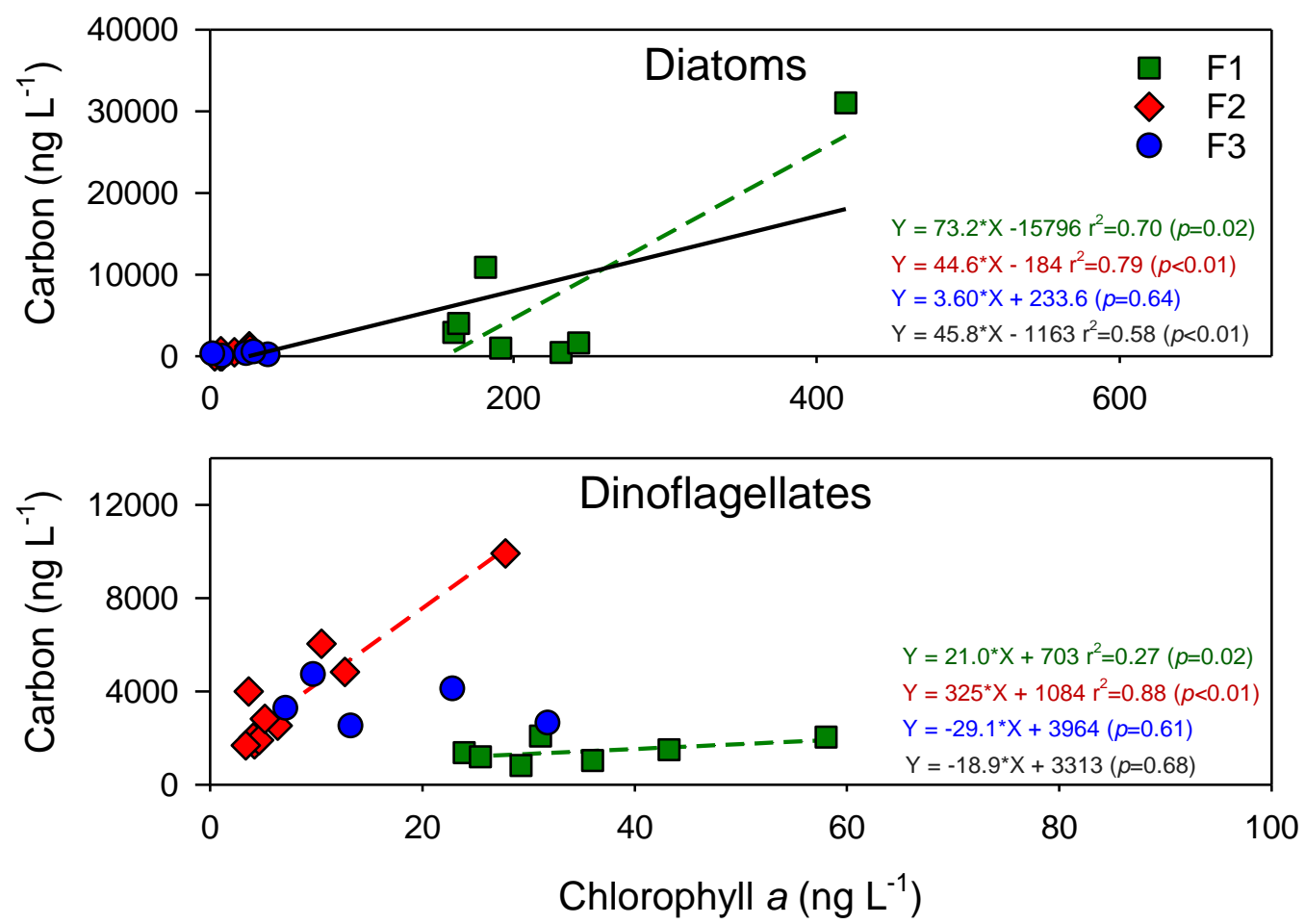

Fig. 7 (cont.) 

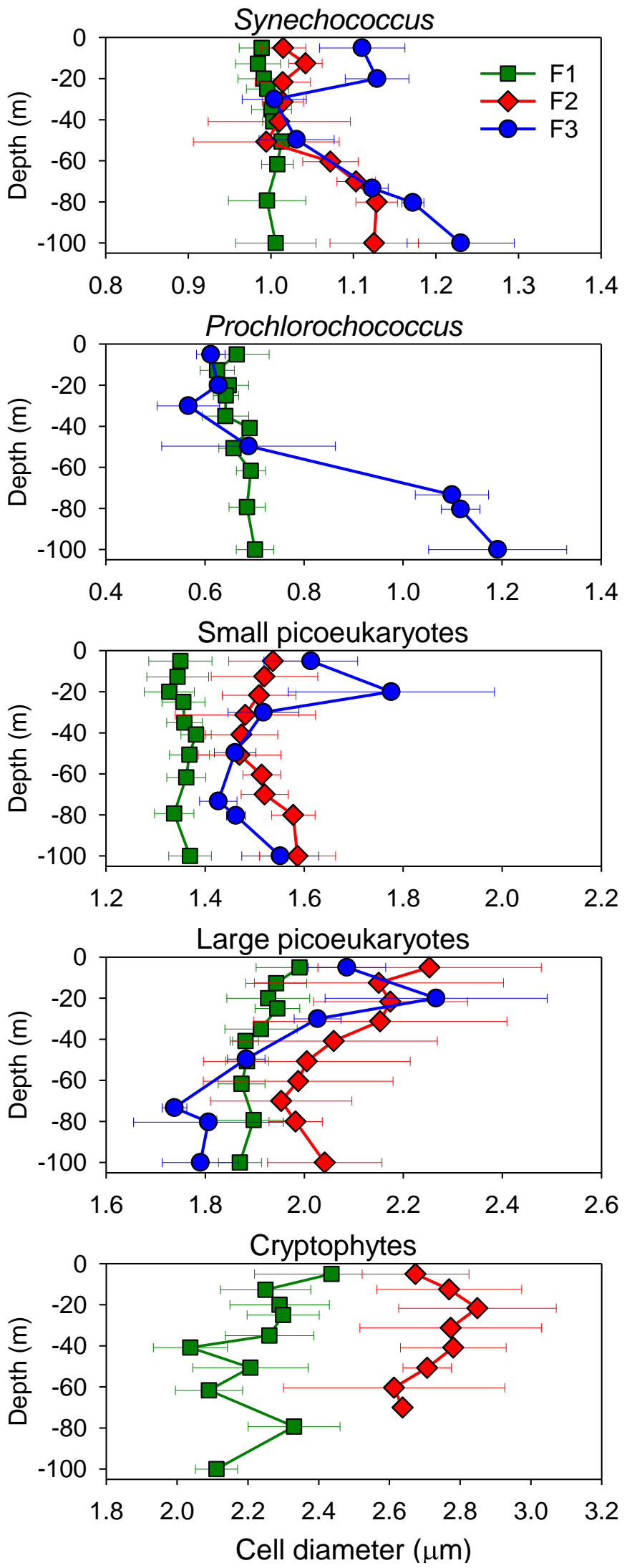

Fig. 8 

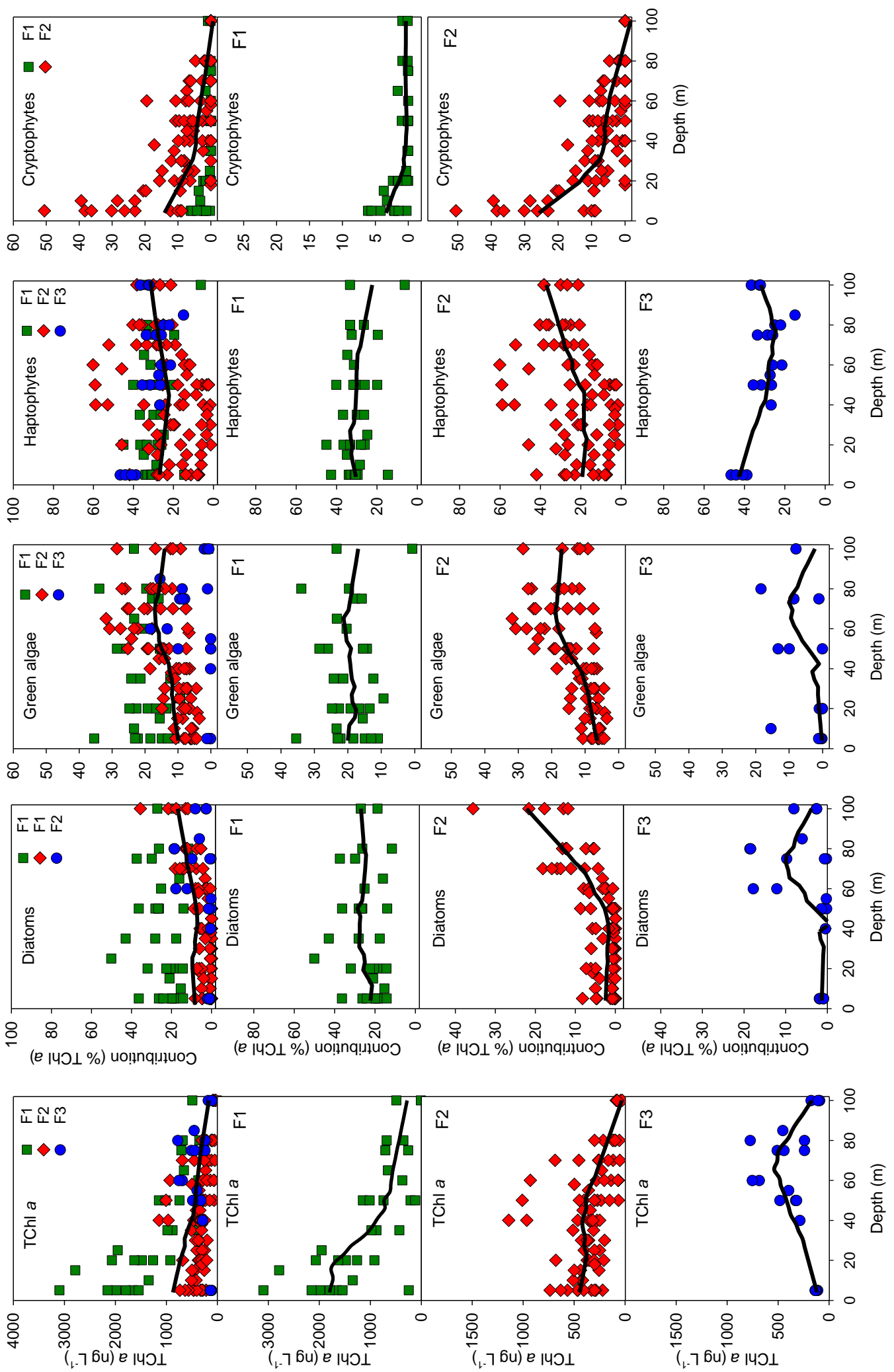

Fig. 9 

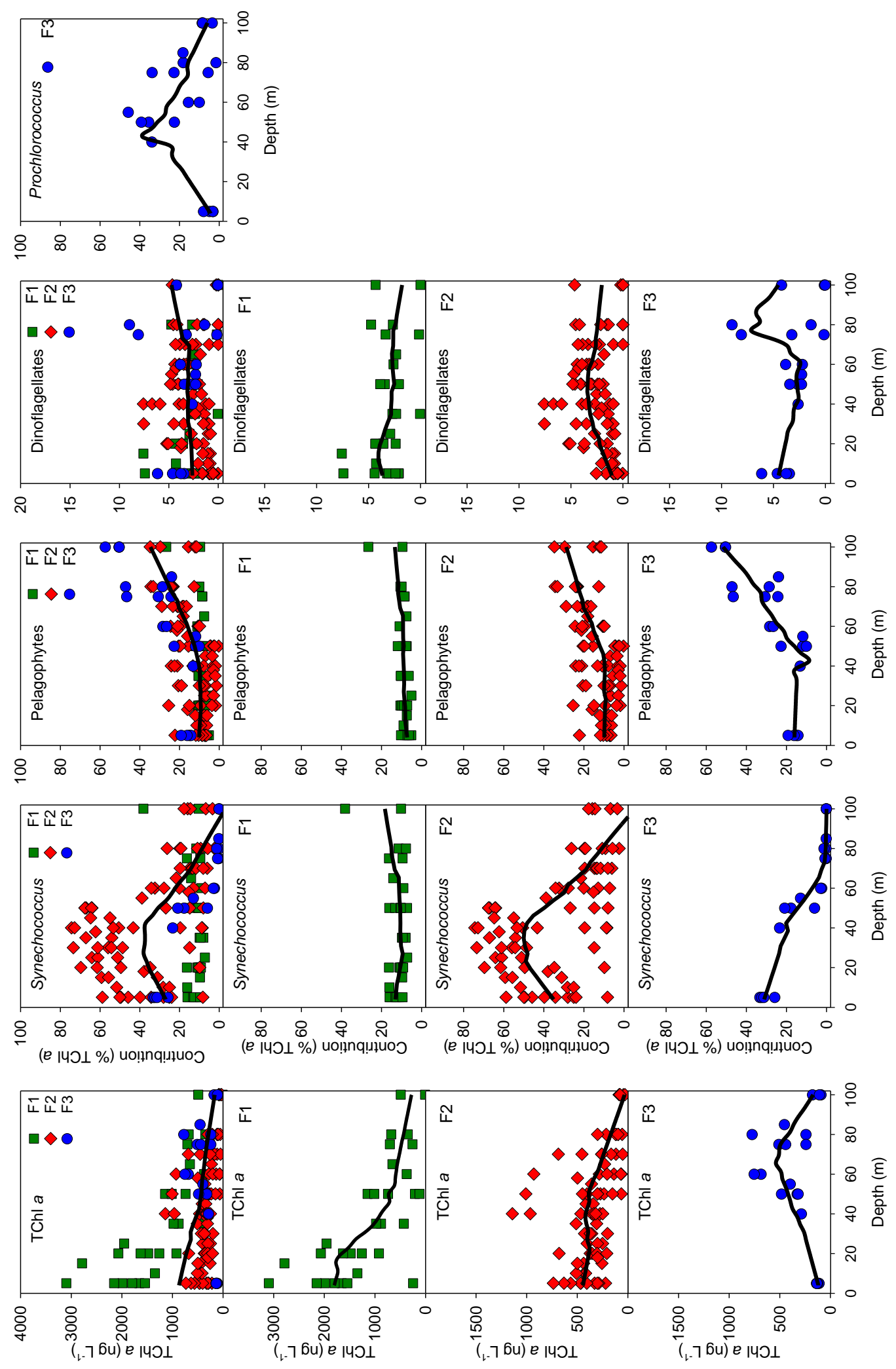

Fig. 9 (cont.) 

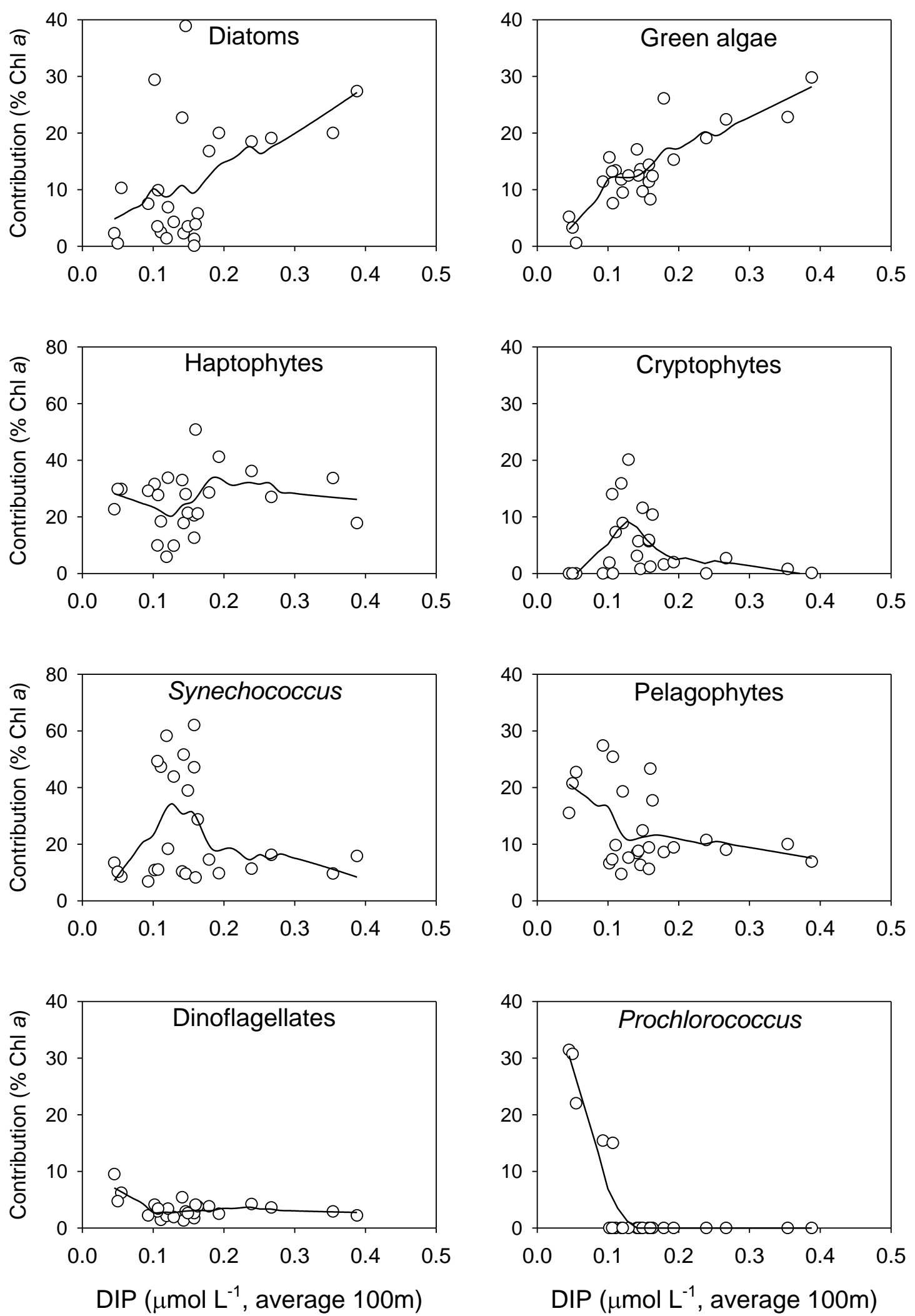

Fig. 10 


\section{Figure Legends}

Figure 1. Surface chlorophyll $a\left(\mu \mathrm{L} \mathrm{L}^{-1}\right)$ and location of the different stations during the three Famoso cruises, F1: March 6 - 23, F2: April 29 - May 14, F3: September 14 - 22. Note the different scales between F1 and F2 and F3. Chlorophyll a images are from March 19, May 7 , and September 19, and are a Copernicus merged product obtained from https://resources.marine.copernicus.eu/?option=com_csw\&task=results.

Figure 2. Environmental conditions during the Famoso cruises. From top to bottom: Potential density, Brunt- Väisälä frequency, Dissolved Inorganic Nitrogen $\left(\mathrm{NO}_{3}{ }^{-}\right)$and Dissolved Inorganic Phosphorus $\left(\mathrm{PO}_{4}{ }^{3-}\right)$. Station numbers are displayed above the top panel; the $\mathrm{x}$-axis represents the temporal scale.

Figure 3. Percent contribution of the different phytoplankton groups to chlorophyll a. during the Famoso cruises. Stations are named above the top panel. Total chlorophyll a concentration ( $\left.\mathrm{TChl}^{a}, \mathrm{ng} \mathrm{L}^{-1}\right)$ in the bottom panel. Station numbers are displayed above the top panel; the $\mathrm{x}$-axis represents the temporal scale.

Figure 4. Biomass distribution of different phytoplankton groups as chlorophyll a (ng L $\mathrm{L}^{-1}$ ) and cell concentrations (cells $\mathrm{mL}^{-1}$ ) for the three Famoso cruises. Station numbers are displayed above the top panel; the $\mathrm{x}$-axis represents the temporal scale.

Figure 5. Carbon to chlorophyll a relationship for the bulk phytoplankton and pico-, nano- and microphytoplankton fractions. Values are averages of the upper $100 \mathrm{~m} . \mathrm{F} 1=$ green square, F2 = red diamond, F3 = blue circle; black 
includes all the data. Regression lines are represented when statistically significant $(p<0.05)$.

Figure 6. A comparative of phytoplankton biomass distribution as chlorophyll a in different size fractions according to UITZ and CHEMTAX approaches.

Figure 7. Carbon to chlorophyll a relationships for different phytoplankton groups. Picoeukaryotes are abbreviated as picoeuk. Large and small picoeukaryotes are populations than can be distinguished by flow cytometry (Table S1). Values are averages of the upper $100 \mathrm{~m}$. Regression lines are represented when statistically significant $(p<0.05) . F 1=$ green square, $F 2=$ red diamond, F3 = blue circle; black includes all the data.

Figure 8. Cell size changes in the water column for different picoplankton groups. $\mathrm{F} 1=$ green square, $\mathrm{F} 2=$ red diamond, $\mathrm{F} 3=$ blue circle.

Figure 9. Percent contribution of the different phytoplankton groups in the upper $100 \mathrm{~m}$ water column. The line represents a smoothed trend (see M\&M) for all cruises (top panel) and for individual cruises. F1= green square, F2 = red diamond, F3 = blue circle.

Figure 10. Percentage contribution of the different phytoplankton groups along the average concentration of dissolved inorganic phosphorus (DIP) in the upper $100 \mathrm{~m}$. The line represents a smoothed trend (see M\&M). Note the different scale for haptophytes and Synechococcus. 
Table 1 Information of stations on date, geolocalization, mixed layer depth (MLD), Brunt- Väisälä (B-V) frequency (cycl $\left.h^{-1}\right)$, dissolved inorganic nitrogen $\left(\mathrm{NO}_{3}{ }^{-}+\mathrm{NO}_{2}{ }^{-}, \mathrm{DIN}\right)$ and dissolved inorganic phosphate $\left(\mathrm{PO}_{4}{ }^{3-}, \mathrm{DIP}\right)$ concentration ( $\left.\mu \mathrm{mol} \mathrm{L}^{-1}\right)$ at surface $(5 \mathrm{~m})$, averaged (avg) or integrated (int) over the 100 $\mathrm{m}$ water column. N.d., no data. Mean and S.D. of MLD in F1 includes $100 \mathrm{~m}$ for station F1-08.

\begin{tabular}{|c|c|c|c|c|c|c|c|c|c|c|}
\hline Cruise & Station & Date & Longitude & Latitude & $\operatorname{MLD}(\mathrm{m})$ & B-V (int 100m) & DIN (5m) & DIN (avg 100m) & $\operatorname{DIP}(5 \mathrm{~m})$ & DIP (avg 100m) \\
\hline F1 & 8 & 2009-03-10 & 4.771 & 41.742 & $>100$ & 28.0 & n.d. & n.d. & 0.357 & 0.388 \\
\hline F1 & 13 & 2009-03-14 & 5.092 & 41.587 & 33 & 181 & 5.86 & 7.26 & 0.118 & 0.239 \\
\hline F1 & 14 & 2009-03-14 & 5.221 & 41.633 & 8 & 199 & 4.33 & 7.09 & 0.145 & 0.267 \\
\hline$\overline{F 1}$ & 16 & 2009-03-15 & 3.862 & 41.503 & 41 & 178 & 4.63 & 6.71 & 0.144 & 0.179 \\
\hline$\overline{F 1}$ & 19 & 2009-03-17 & 3.822 & 41.274 & 13 & 193 & n.d. & n.d. & 0.056 & 0.193 \\
\hline F1 & 21 & 2009-03-18 & 4.075 & 41.501 & 15 & 128 & 5.82 & 8.08 & 0.209 & 0.354 \\
\hline F1 & 24 & 2009-03-19 & 4.257 & 41.608 & 24 & 184 & 2.97 & 5.92 & 0.040 & 0.141 \\
\hline F1 & 27 & 2009-03-21 & 4.305 & 41.827 & 36 & 120 & 3.71 & 5.34 & 0.068 & 0.102 \\
\hline$\overline{F 1}$ & 31 & 2009-03-22 & 4.569 & 41.794 & 65 & 100 & 3.83 & 5.15 & 0.104 & 0.146 \\
\hline Mean (SD) & & & & & $37( \pm 29)$ & $146( \pm 57)$ & $4.45( \pm 1.08$ & $6.51( \pm 1.08)$ & $0.138( \pm 0.097)$ & $0.223( \pm 0.098)$ \\
\hline$\overline{F 2}$ & 5 & $2009-04-30$ & 4.874 & 41.5 & 26 & 282 & 2.78 & 4.19 & 0.012 & 0.143 \\
\hline F2 & 11 & 2009-05-03 & 3.939 & 41.499 & 37 & 339 & 1.02 & 4.93 & 0.019 & 0.158 \\
\hline $\bar{F} 2$ & 12 & $2009-05-03$ & 3.952 & 41.512 & 12 & 434 & 1.02 & 4.93 & 0.019 & 0.158 \\
\hline F2 & 15 & 2009-05-04 & 3.958 & 41.557 & 26 & 366 & 1.30 & 4.10 & 0.040 & 0.111 \\
\hline F2 & 20 & 2009-05-07 & 4.54 & 42.112 & 10 & 261 & 1.79 & 4.26 & 0.026 & 0.119 \\
\hline$\overline{F 2}$ & 26 & $2009-05-08$ & 4.06 & 42.026 & 11 & 329 & 1.57 & 4.44 & 0.053 & 0.129 \\
\hline F2 & 30 & 2009-05-09 & 4.098 & 42.054 & 11 & 380 & 1.34 & 5.17 & 0.009 & 0.106 \\
\hline F2 & 32 & $2009-05-10$ & 4.165 & 42.047 & 10 & 382 & 1.23 & 4.48 & 0.021 & 0.149 \\
\hline$\overline{F 2}$ & 36 & $2009-05-11$ & 4.595 & 41.459 & 7 & 369 & 1.06 & 4.26 & 0.038 & 0.163 \\
\hline F2 & 40 & 2009-05-12 & 4.532 & 41.385 & 15 & 379 & 2.16 & 4.90 & 0.030 & 0.121 \\
\hline F2 & 44 & 2009-05-13 & 4.486 & 41.339 & 7 & 428 & 0.701 & 3.55 & 0.057 & 0.160 \\
\hline Mean (SD) & & & & & $16( \pm 10)$ & $359( \pm 54)$ & $1.45( \pm 0.60)$ & $4.47( \pm 0.47)$ & $0.029( \pm 0.016)$ & $0.138( \pm 0.021)$ \\
\hline$\overline{\text { F3 }}$ & 5 & 2009-09-16 & 4.304 & 41.483 & 36 & 515 & n.d. & n.d. & 0.032 & 0.055 \\
\hline F3 & 8 & 2009-09-17 & 4.232 & 41.473 & 16 & 670 & 1.48 & 3.34 & 0.036 & 0.045 \\
\hline$\overline{\text { F3 }}$ & 12 & 2009-09-18 & 4.208 & 41.477 & 26 & 609 & 1.87 & 1.75 & 0.016 & 0.050 \\
\hline F3 & 15 & 2009-09-19 & 4.044 & 41.929 & 30 & 524 & 0.730 & 3.50 & 0.024 & 0.093 \\
\hline$\overline{F 3}$ & 20 & $2009-09-20$ & 4.086 & 41.937 & 6 & 628 & 1.83 & 3.64 & 0.049 & 0.107 \\
\hline Mean (SD) & & & & & $23( \pm 12)$ & $589( \pm 67)$ & $1.48( \pm 0.53)$ & $3.06( \pm 0.88)$ & $0.031( \pm 0.012)$ & $0.070( \pm 0.028)$ \\
\hline
\end{tabular}


Table 2. Distribution of chlorophyll $a$ in the different phytoplankton groups and across size fractions using CHEMTAX, and of phytoplankton carbon estimated from microscopy and flow cytometry cell concentrations and biovolume to carbon conversion. Values (ng L ${ }^{-1}$ or $\left.\mu_{\mathrm{g} \mathrm{L}^{-1}}\right)$ are averages of the $100 \mathrm{~m}$ depth water column integrated following the trapezoidal rule (see M\&M). Percentages are estimates per cruise referred to chlorophyll a or carbon.

$\begin{array}{llllll}\text { F1 } & \text { F2 } & \text { F3 } & \text { F1 }(\%) & \text { F2 (\%) } & \text { F3 (\%) }\end{array}$

Chl a (ng L-1)

\begin{tabular}{lrrrrrr}
\hline Total & $843( \pm 313)$ & $297( \pm 137)$ & $318( \pm 36)$ & & & \\
\hline Picoplankton & $256( \pm 90)$ & $141( \pm 43)$ & $122( \pm 27)$ & 30 & 48 & 38 \\
\hline Nanoplankton & $360( \pm 163)$ & $138( \pm 132)$ & $159( \pm 27)$ & 43 & 46 & 50 \\
\hline Microplankton & $227( \pm 109)$ & $18( \pm 15)$ & $37( \pm 17)$ & 27 & 6 & 12 \\
\hline Diatoms & $197( \pm 101)$ & $10( \pm 8.8)$ & $20( \pm 15)$ & 23 & 3 & 6 \\
\hline Dinoflagellates & $31( \pm 15)$ & $8.2( \pm 7.2)$ & $17( \pm 10)$ & 4 & 3 & 5 \\
\hline Haptophytes & $274( \pm 128)$ & $74( \pm 94)$ & $88( \pm 14)$ & 32 & 25 & 28 \\
\hline Pelagophytes & $73( \pm 32)$ & $40( \pm 43)$ & $71( \pm 15)$ & 9 & 13 & 22 \\
\hline Cryptophytes & $13( \pm 11)$ & $24( \pm 9.2)$ & 0 & 2 & 8 & 0 \\
\hline Green algae & $160( \pm 58)$ & $33( \pm 10)$ & $17( \pm 13)$ & 19 & 11 & 5 \\
\hline Synechococcus & $96( \pm 34)$ & $108( \pm 42)$ & $32( \pm 8.3)$ & 11 & 36 & 10 \\
\hline Prochlorococcus & 0 & 0 & $73( \pm 26)$ & 0 & 0 & 23 \\
\hline Carbon $\left(\mu \mathbf{~ L ~ L ~}^{-1}\right)$ & & & & &
\end{tabular}

\begin{tabular}{|c|c|c|c|c|c|c|}
\hline Total & $20.02( \pm 10.26)$ & $18.19( \pm 6.06)$ & $9.95( \pm 1.06)$ & & & \\
\hline Picoplankton & $8.77( \pm 3.17)$ & $11.68( \pm 6.26)$ & $5.21( \pm 0.61)$ & 44 & 64 & 52 \\
\hline Nanoplankton & $2.26( \pm 1.30)$ & $2.92( \pm 1.08)$ & $1.99( \pm 0.60)$ & 11 & 16 & 20 \\
\hline Microplankton & $8.99( \pm 10.29)$ & $3.59( \pm 3.32)$ & $2.75( \pm 1.00)$ & 45 & 20 & 28 \\
\hline Prochlorococcus & $0.04( \pm 0.03)$ & 0.00 & $2.63( \pm 0.41)$ & 0 & 0 & 26 \\
\hline Synechococcus & $3.64( \pm 1.42)$ & $9.92( \pm 6.38)$ & $1.65( \pm 0.57)$ & 18 & 55 & 17 \\
\hline Picoeukaryotes & $4.97( \pm 1.85)$ & $1.56( \pm 1.02)$ & $0.92( \pm 0.33)$ & 25 & 9 & 9 \\
\hline Cryptophytes $^{a}$ & $0.12( \pm 0.06)$ & $0.18( \pm 0.12)$ & 0.00 & 1 & 1 & 0 \\
\hline Diatoms $<20 \mu \mathrm{m}^{\mathrm{b}}$ & $0.02( \pm 0.02)$ & 0.00 & $0.01( \pm 0.02)$ & 0 & 0 & 0 \\
\hline Dinoflagellates $<20 \mu \mathrm{m}$ & $0.46( \pm 0.29)$ & $1.29( \pm 0.66)$ & $1.17( \pm 0.40)$ & 2 & 7 & 12 \\
\hline Flagellates $<20 \mu \mathrm{m}$ & $1.72( \pm 1.21)$ & $1.63( \pm 0.47)$ & $0.73( \pm 0.25)$ & 9 & 9 & 7 \\
\hline Other $<20 \mu \mathrm{m}$ & $0.05( \pm 0.07)$ & 0.00 & $0.08( \pm 0.06)$ & 0 & 0 & 1 \\
\hline Diatoms $>20 \mu \mathrm{m}^{\mathrm{c}}$ & $7.41( \pm 9.74)$ & $0.33( \pm 0.44)$ & $0.29( \pm 0.19)$ & 37 & 2 & 3 \\
\hline Dinoflagellates $>20 \mu \mathrm{m}$ & $0.99( \pm 0.46)$ & $2.47( \pm 1.89)$ & $2.30( \pm 0.90)$ & 5 & 14 & 23 \\
\hline Other $>20 \mu \mathrm{m}$ & $0.60( \pm 0.38)$ & $0.79( \pm 1.19)$ & $0.16( \pm 0.08)$ & 3 & 4 & 1 \\
\hline
\end{tabular}


Table 3 Chlorophyll a attributed to the different phytoplankton groups by CHEMTAX per station. Average concentration (ng L-1) in the $100 \mathrm{~m}^{-1}$ water column.

\begin{tabular}{|c|c|c|c|c|c|c|c|c|c|c|}
\hline Cruise & Station & Cryptophytes & Diatoms & Dinoflagellates & Green algae & Haptophytes & Pelagophytes & Synechococcus & Prochlorococcus & Chl $a$ \\
\hline$\overline{F 1}$ & 8 & 0.2 & 46.0 & 3.7 & 50.1 & 29.9 & 11.6 & 26.6 & 0.0 & 168.2 \\
\hline F1 & 13 & 0.4 & 191.5 & 43.3 & 198.0 & 374.2 & 110.3 & 116.9 & 0.0 & 1034.6 \\
\hline$\overline{F 1}$ & 14 & 18.7 & 132.3 & 24.7 & 154.9 & 186.3 & 62.3 & 112.0 & 0.0 & 691.1 \\
\hline F1 & 16 & 15.6 & 160.6 & 36.0 & 249.4 & 273.2 & 82.4 & 139.0 & 0.0 & 956.3 \\
\hline F1 & 19 & 22.9 & 231.3 & 29.3 & 176.5 & 476.3 & 108.5 & 112.0 & 0.0 & 1156.7 \\
\hline$\overline{F 1}$ & 21 & 6.7 & 163.8 & 23.9 & 186.4 & 275.5 & 82.1 & 78.5 & 0.0 & 817.0 \\
\hline F1 & 24 & 33.1 & 242.9 & 58.0 & 183.4 & 353.2 & 89.8 & 110.0 & 0.0 & 1070.4 \\
\hline F1 & 27 & 11.9 & 181.6 & 25.5 & 96.7 & 195.0 & 40.6 & 66.7 & 0.0 & 618.0 \\
\hline$\overline{F 1}$ & 31 & 8.1 & 419.3 & 31.1 & 145.9 & 301.9 & 68.3 & 102.3 & 0.0 & 1076.9 \\
\hline F2 & 5 & 18.0 & 7.3 & 4.2 & 39.4 & 56.1 & 27.8 & 162.5 & 0.0 & 315.3 \\
\hline F2 & 11 & 13.7 & 3.1 & 4.1 & 34.8 & 49.3 & 22.6 & 113.6 & 0.0 & 241.2 \\
\hline $\mathrm{F} 2$ & 12 & 18.2 & 0.3 & 7.9 & 35.0 & 38.7 & 17.2 & 191.0 & 0.0 & 308.3 \\
\hline F2 & 15 & 18.7 & 6.5 & 3.6 & 34.5 & 47.5 & 25.3 & 122.1 & 0.0 & 258.3 \\
\hline $\mathrm{F} 2$ & 20 & 35.2 & 3.0 & 4.6 & 26.3 & 13.1 & 10.5 & 129.2 & 0.0 & 221.9 \\
\hline F2 & 26 & 35.0 & 7.4 & 3.3 & 21.9 & 17.1 & 13.2 & 76.5 & 0.0 & 174.5 \\
\hline F2 & 30 & 31.1 & 7.9 & 6.4 & 29.3 & 22.0 & 16.1 & 109.6 & 0.0 & 222.3 \\
\hline F2 & 32 & 23.4 & 7.0 & 5.1 & 19.6 & 43.1 & 24.9 & 78.2 & 0.0 & 201.3 \\
\hline F2 & 36 & 28.8 & 16.0 & 10.5 & 34.4 & 58.7 & 49.1 & 79.4 & 0.0 & 276.9 \\
\hline F2 & 40 & 33.2 & 25.7 & 12.7 & 35.4 & 126.4 & 72.0 & 68.5 & 0.0 & 374.0 \\
\hline F2 & 44 & 8.3 & 26.2 & 27.8 & 55.8 & 341.5 & 156.7 & 55.4 & 0.0 & 671.8 \\
\hline F3 & 5 & 0.0 & 38.0 & 22.8 & 2.2 & 110.1 & 83.8 & 31.5 & 81.3 & 369.8 \\
\hline F3 & 8 & 0.0 & 7.6 & 31.8 & 17.5 & 75.8 & 51.8 & 44.6 & 104.8 & 333.9 \\
\hline F3 & 12 & 0.0 & 1.5 & 13.2 & 9.4 & 84.6 & 58.8 & 28.8 & 87.1 & 283.5 \\
\hline F3 & 15 & 0.0 & 23.6 & 7.1 & 36.1 & 92.4 & 86.7 & 21.5 & 48.8 & 316.1 \\
\hline F3 & 20 & 0.0 & 28.5 & 9.7 & 21.8 & 79.4 & 72.8 & 31.6 & 43.0 & 286.7 \\
\hline
\end{tabular}


Table 4 Microscopy estimations of nano and microphytoplankton carbon (C) biomass per station. Average concentration (ng $\mathrm{L}^{-1}$ ) in the $100 \mathrm{~m}$ water column. Total autotrophic C includes picophytoplankton C estimated from FCM counts.

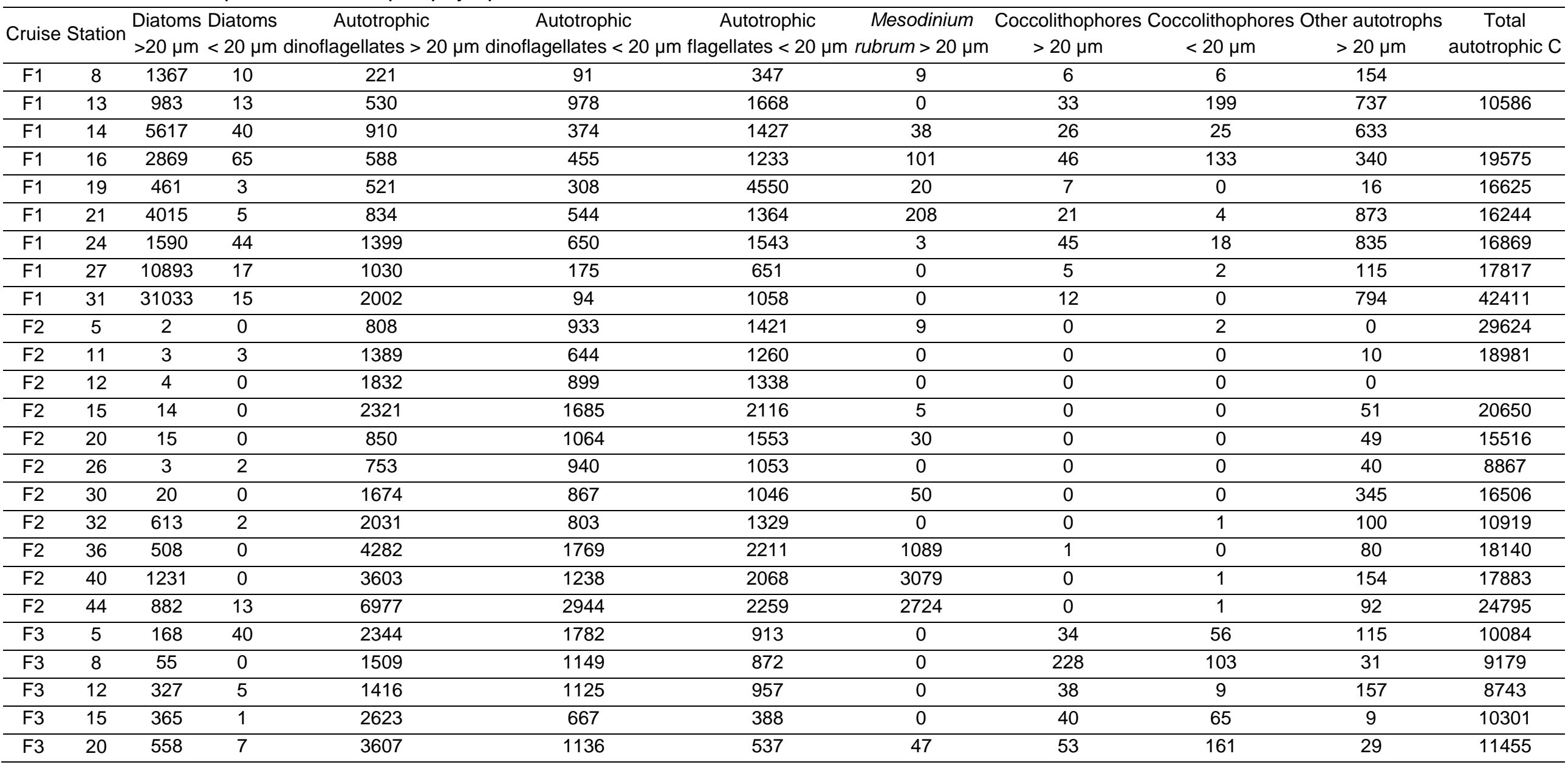

Diatoms $>20 \mu \mathrm{m}$ include chain-forming species with individual cells $<20 \mu \mathrm{m}$.

Diatoms $<20 \mu \mathrm{m}$ are non chain-forming cells.

Mesodinium rubrum is a ciliate, autotrophic due to endosymbiontic cryptophytes.

Flagellates $<20 \mu \mathrm{m}$ refer to non-skeletal, non-colony forming cells.

Other autotrophs $>20 \mu \mathrm{m}$ include phycoma stages of Prasinophyceae, colonial formas of Phaeocystis and non-skeletal, non-colony forming cells and colonies of

flagellates.

Total autotrophic C includes picoplankton. 
Table 5 Flow cytometry estimations of picophytoplankton carbon biomass in different groups per station. Average concentration (ng $\mathrm{L}^{-1}$ ) in the $100 \mathrm{~m}^{2}$ water column.

\begin{tabular}{|c|c|c|c|c|c|c|c|c|c|}
\hline Cruise & Station & Synechococcus & Prochlorococcus & $\begin{array}{c}\text { Small } \\
\text { picoeukaryotes }\end{array}$ & $\begin{array}{c}\text { Large } \\
\text { picoeukaryotes }\end{array}$ & $\begin{array}{c}\text { Total } \\
\text { picoeukaryotes }\end{array}$ & Cryptophytes & Picophytoplankton & $\begin{array}{c}\text { Total } \\
\text { autotrophic C }\end{array}$ \\
\hline F1 & 8 & & & & & & & & \\
\hline $\mathrm{F} 1$ & 13 & 2264 & 17 & 1360 & 1711 & 3071 & 92 & 5444 & 10586 \\
\hline $\mathrm{F} 1$ & 14 & & & & & & & & \\
\hline $\mathrm{F} 1$ & 16 & 6247 & 93 & 4153 & 3125 & 7278 & 130 & 13747 & 19575 \\
\hline $\mathrm{F} 1$ & 19 & 3715 & 28 & 1891 & 4876 & 6767 & 229 & 10739 & 16625 \\
\hline $\mathrm{F} 1$ & 21 & 2878 & 37 & 2521 & 2845 & 5366 & 93 & 8374 & 16244 \\
\hline $\mathrm{F} 1$ & 24 & 4582 & 41 & 2187 & 3769 & 5956 & 162 & 10741 & 16869 \\
\hline $\mathrm{F} 1$ & 27 & 2260 & 14 & 849 & 1704 & 2553 & 102 & 4930 & 17817 \\
\hline $\mathrm{F} 1$ & 31 & 3509 & 25 & 1717 & 2091 & 3808 & 60 & 7403 & 42411 \\
\hline $\mathrm{F} 2$ & 5 & 24816 & 0 & 1067 & 471 & 1538 & 95 & 26448 & 29624 \\
\hline F2 & 11 & 13615 & 0 & 998 & 989 & 1987 & 70 & 15671 & 18981 \\
\hline $\mathrm{F} 2$ & 12 & & & & & & & & \\
\hline F2 & 15 & 12877 & 0 & 829 & 655 & 1484 & 97 & 14458 & 20650 \\
\hline F2 & 20 & 10997 & 0 & 630 & 118 & 636 & 208 & 11953 & 15516 \\
\hline $\mathrm{F} 2$ & 26 & 5250 & 0 & 423 & 158 & 581 & 246 & 6077 & 8867 \\
\hline F2 & 30 & 11288 & 0 & 792 & 134 & 926 & 290 & 12503 & 16506 \\
\hline F2 & 32 & 5012 & 0 & 406 & 468 & 874 & 154 & 6040 & 10919 \\
\hline F2 & 36 & 6571 & 0 & 678 & 715 & 1393 & 237 & 8200 & 18140 \\
\hline $\mathrm{F} 2$ & 40 & 3947 & 0 & 779 & 1357 & 2137 & 426 & 6510 & 17883 \\
\hline F2 & 44 & 4838 & 0 & 880 & 3163 & 4043 & 21 & 8902 & 24795 \\
\hline F3 & 5 & 1282 & 2719 & 161 & 471 & 631 & 0 & 4633 & 10084 \\
\hline F3 & 8 & 1353 & 3120 & 200 & 559 & 758 & 0 & 5231 & 9179 \\
\hline F3 & 12 & 1128 & 2887 & 128 & 564 & 692 & 0 & 4708 & 8743 \\
\hline F3 & 15 & 2444 & 2304 & 452 & 943 & 1395 & 0 & 6142 & 10301 \\
\hline F3 & 20 & 2057 & 2119 & 337 & 807 & 1144 & 0 & 5320 & 11455 \\
\hline
\end{tabular}

No data for F1-08, F1-14, F2-12.

Average diameter of large and small picoeukaryotes are $1.97 \mu \mathrm{m}$ and $1.45 \mu \mathrm{m}$ (Table S1). 


\section{Supplementary material}

\section{Dynamics of phytoplankton groups in three contrasting situations of the open NW} Mediterranean revealed by pigment, microscopy, and flow cytometry analyses

Mikel Latasa $^{a}$, Renate Schareka ${ }^{a}$ Xosé Anxelu G. Morána,b, Andrés Gutiérrez-Rodríguez ${ }^{\mathrm{c}}$, Mikhail Emelianov ${ }^{d}$, Jordi Salat ${ }^{d}$, Montserrat Vidale, Marta Estrada ${ }^{d}$

a Centro Oceanográfico de Gijón/Xixón (IEO), Avda. Príncipe de Asturias 70bis, 33212, Gijón/Xixón, Asturias, Spain

${ }^{b}$ King Abdullah University of Science and Technology (KAUST), Thuwal, Saudi Arabia

${ }^{c}$ National Institute of Water and Atmospheric research (NIWA), 301 Evans Bay, Hataitai, Wellington, New Zealand

d Institut de Ciències del Mar, CSIC, Pg. Marítim de la Barceloneta, 37-49, 08003, Barcelona, Catalunya, Spain

e Departament de Biologia Evolutiva, Ecologia i Ciències Ambientals. Facultat de Biologia, Universitat de Barcelona. Av. Diagonal, 643, 08028. Barcelona, Catalunya, Spain

Corresponding author: mikel.latasa@ieo.es 
Table S1. Overall average cell diameter $(\mu \mathrm{m})$ and carbon content $\left(\mathrm{pg} \mathrm{cell} \mathrm{l}^{-1}\right)$ of picophytoplankton groups by FCM. Standard deviation and number of samples are indicated in parenthesis.

1

2

\begin{tabular}{lcc}
\hline & Cell diameter & Cell carbon content \\
\hline Prochlorococcus & $0.71( \pm 0.164,121)$ & $0.053( \pm 0.051,121)$ \\
Synechococcus & $1.04( \pm 0.071,230)$ & $0.152( \pm 0.162,230)$ \\
Small picoeukaryotes & $1.45( \pm 0.12,219)$ & $0.388( \pm 0.102,219)$ \\
Large picoeukaryotes & $1.97( \pm 0.17,217)$ & $0.975( \pm 0.277,217)$ \\
Cryptophytes (small) & $2.42( \pm 0.31,114)$ & $1.805( \pm 0.767,114)$ \\
\hline
\end{tabular}


Table S2. Excel template for initial input random matrices for Chemtax.

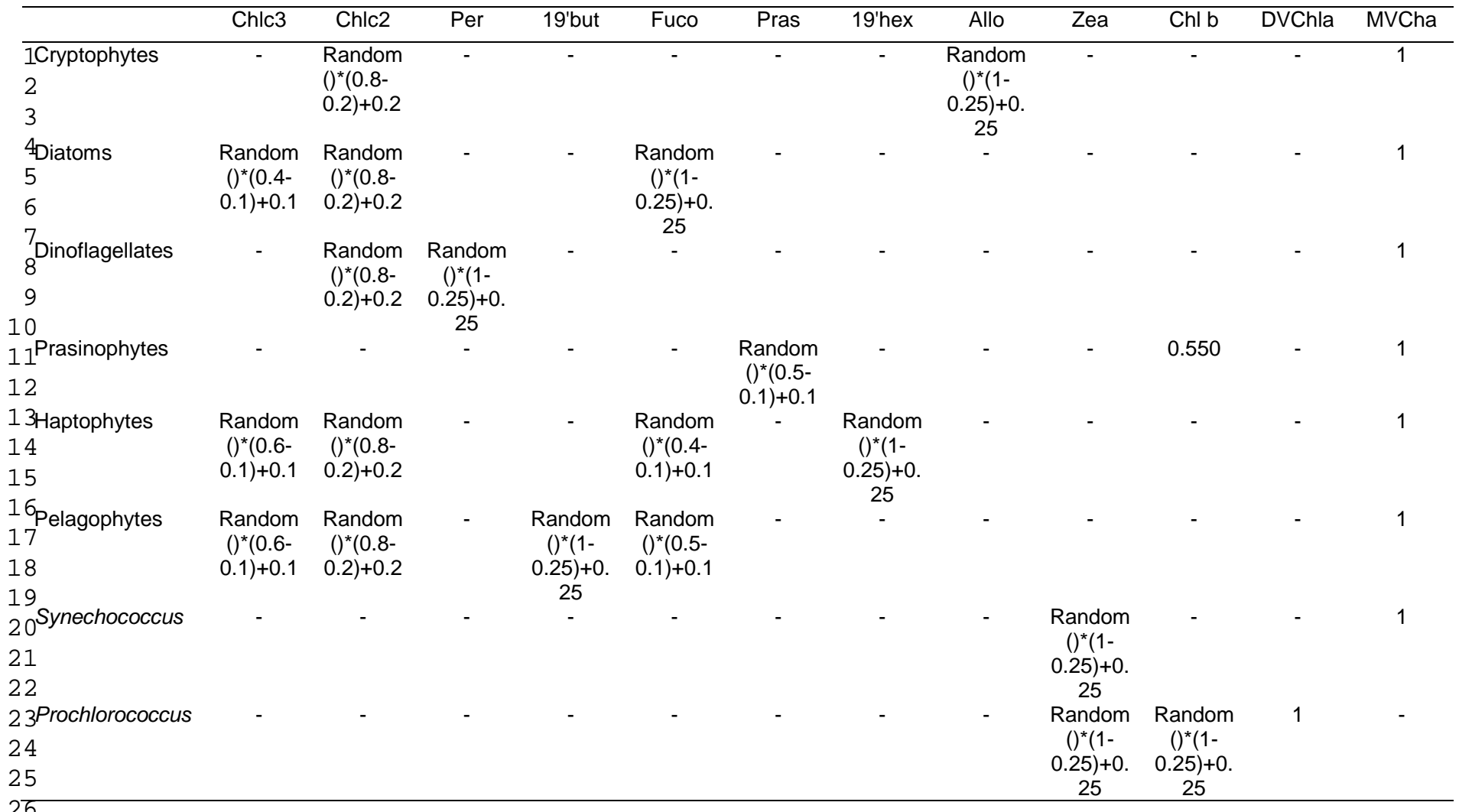

27

280utput Chemtax matrices for the five pigment clusters.

\begin{tabular}{|c|c|c|c|c|c|c|c|c|c|c|c|c|}
\hline $\begin{array}{l}29 \\
30\end{array}$ & Chlc3 & Chlc2 & Per & 19'but & Fuco & Pras & 19'hex & Allo & Zea & Chl b & DVChla & MVCha \\
\hline \multicolumn{13}{|l|}{ 31Cluster1 } \\
\hline $\begin{array}{l}{ }^{32} \text { Cryptophytes } \\
33^{2}\end{array}$ & - & 0.369 & - & - & - & - & - & 0.654 & - & - & - & 1 \\
\hline 34Diatoms & 0.206 & 0.462 & - & - & 0.686 & - & - & - & - & - & - & 1 \\
\hline $\begin{array}{l}\text { 35Dinoflagellates } \\
36\end{array}$ & - & 0.522 & 0.648 & - & - & - & - & - & - & - & - & 1 \\
\hline 37 Prasinophytes & - & - & - & - & - & 0.174 & - & - & - & 0.689 & - & 1 \\
\hline 38Haptophytes & 0.830 & 0.321 & - & - & 0.088 & - & 0.611 & - & - & - & - & 1 \\
\hline $4{ }^{39}$ Pelagophytes & 0.333 & 0.419 & - & 0.811 & 0.189 & - & - & - & - & - & - & 1 \\
\hline 41Synechococcus & - & - & - & - & - & - & - & - & 0.574 & - & - & 1 \\
\hline${ }_{43}^{42}$ Prochlorococcus & - & - & - & - & - & - & - & - & 0.569 & 0.542 & 1 & - \\
\hline
\end{tabular}

44 Cluster2

${ }_{46}^{45}$ Cryptophytes

47Diatoms

${ }_{49}^{4}$ Dinoflagellates

$-\quad 0.402$

$-\quad-\quad-\quad 0.595$

$0.271 \quad 0.290$

0.574

- $\quad 0.4320 .533$

50Prasinophytes

${ }_{52}^{51}$ Haptophytes

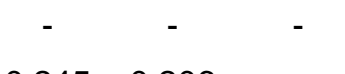

0.131

0.508

53 Pelagophytes

${ }_{55}^{54}$ Synechococcus

$0.245 \quad 0.206$

0.275

0.770

$0.364 \quad 0.260$

$0.704 \quad 0.200$

56 Prochlorococcus

${ }_{58}^{57}$ Cluster3

59 Cryptophytes

0.361

$\begin{array}{ll}0.182 & 0.259\end{array}$

0.803

0.590 


\begin{tabular}{|c|c|c|c|c|c|c|c|c|c|c|c|c|}
\hline Dinoflagellates & - & 0.481 & 0.596 & - & - & - & - & - & - & - & - & 1 \\
\hline Prasinophytes & - & - & - & - & - & 0.148 & - & - & - & 0.621 & - & 1 \\
\hline${ }_{2}$ Haptophytes & 0.377 & 0.275 & - & - & 0.106 & - & 0.732 & - & - & - & - & 1 \\
\hline 3Pelagophytes & 0.191 & 0.263 & - & 0.854 & 0.279 & - & - & - & - & - & - & 1 \\
\hline${ }_{5}^{4}$ Synechococcus & - & - & - & - & - & - & - & - & 0.583 & - & - & 1 \\
\hline 6Prochlorococcus & - & - & - & - & - & - & - & - & 0.620 & 0.546 & 1 & - \\
\hline \multicolumn{13}{|l|}{${ }_{8}^{7}$ Cluster4 } \\
\hline 9Cryptophytes & - & 0.516 & - & - & - & - & - & 0.504 & - & - & - & 1 \\
\hline $\begin{array}{l}10 \text { Diatoms } \\
11\end{array}$ & 0.260 & 0.399 & - & - & 0.639 & - & - & - & - & - & - & 1 \\
\hline 12 Dinoflagellates & - & 0.374 & 0.620 & - & - & - & - & - & - & - & - & 1 \\
\hline 13Prasinophytes & - & - & - & - & - & 0.164 & - & - & - & 0.679 & - & 1 \\
\hline $\begin{array}{l}14 \\
15 \text { Haptophytes }\end{array}$ & 0.337 & 0.261 & - & - & 0.073 & - & 0.991 & - & - & - & - & 1 \\
\hline 16Pelagophytes & 0.470 & 0.132 & - & 0.745 & 0.262 & - & - & - & - & - & - & 1 \\
\hline 18 Synechococcus & - & - & - & - & - & - & - & - & 0.644 & - & - & 1 \\
\hline 19Prochlorococcus & - & - & - & - & - & - & - & - & 0.400 & 0.701 & 1 & - \\
\hline \multicolumn{13}{|l|}{${ }_{21}$ Cluster5 } \\
\hline 22Cryptophytes & - & 0.427 & - & - & - & - & - & 0.546 & - & - & - & 1 \\
\hline $24^{\text {Diatoms }}$ & 0.152 & 0.226 & - & - & 0.645 & - & - & - & - & - & - & 1 \\
\hline 25Dinoflagellates & - & 0.422 & 0.516 & - & - & - & - & - & - & - & - & 1 \\
\hline${ }_{27}^{26}$ Prasinophytes & - & - & - & - & - & 0.155 & - & - & - & 0.535 & - & 1 \\
\hline 28Haptophytes & 0.322 & 0.194 & - & - & 0.141 & - & 0.820 & - & - & - & - & 1 \\
\hline${ }_{30}^{29}$ Pelagophytes & 0.400 & 0.199 & - & 0.766 & 0.191 & - & - & - & - & - & - & 1 \\
\hline 31Synechococcus & - & - & - & - & - & - & - & - & 0.421 & - & - & 1 \\
\hline $\begin{array}{l}32 \text { Prochlorococcus } \\
33\end{array}$ & - & - & - & - & - & - & - & - & 0.606 & 0.693 & 1 & - \\
\hline
\end{tabular}


Table S3 Percent contribution of phytoplankton groups to total chlorophyll a biomass per station.

\begin{tabular}{|c|c|c|c|c|c|c|c|c|c|}
\hline Cruise & Station & Cryptophytes & Diatoms & Dinoflagellates & Green algae & Haptophytes & Pelagophytes & Synechococcus & Prochlorococcus \\
\hline$\overline{F 1}$ & 8 & 0.1 & 27.4 & 2.2 & 29.8 & 17.8 & 6.9 & 15.8 & 0.0 \\
\hline F1 & 13 & 0.0 & 18.5 & 4.2 & 19.1 & 36.2 & 10.7 & 11.3 & 0.0 \\
\hline F1 & 14 & 2.7 & 19.1 & 3.6 & 22.4 & 27.0 & 9.0 & 16.2 & 0.0 \\
\hline$\overline{F 1}$ & 16 & 1.6 & 16.8 & 3.8 & 26.1 & 28.6 & 8.6 & 14.5 & 0.0 \\
\hline$\overline{F 1}$ & 19 & 2.0 & 20.0 & 2.5 & 15.3 & 41.2 & 9.4 & 9.7 & 0.0 \\
\hline F1 & 21 & 0.8 & 20.0 & 2.9 & 22.8 & 33.7 & 10.0 & 9.6 & 0.0 \\
\hline F1 & 24 & 3.1 & 22.7 & 5.4 & 17.1 & 33.0 & 8.4 & 10.3 & 0.0 \\
\hline F1 & 27 & 1.9 & 29.4 & 4.1 & 15.7 & 31.6 & 6.6 & 10.8 & 0.0 \\
\hline F1 & 31 & 0.8 & 38.9 & 2.9 & 13.6 & 28.0 & 6.3 & 9.5 & 0.0 \\
\hline F2 & 5 & 5.7 & 2.3 & 1.3 & 12.5 & 17.8 & 8.8 & 51.6 & 0.0 \\
\hline F2 & 11 & 5.7 & 1.3 & 1.7 & 14.4 & 20.5 & 9.4 & 47.1 & 0.0 \\
\hline F2 & 12 & 5.9 & 0.1 & 2.6 & 11.4 & 12.6 & 5.6 & 62.0 & 0.0 \\
\hline F2 & 15 & 7.3 & 2.5 & 1.4 & 13.4 & 18.4 & 9.8 & 47.3 & 0.0 \\
\hline F2 & 20 & 15.9 & 1.4 & 2.1 & 11.8 & 5.9 & 4.7 & 58.2 & 0.0 \\
\hline F2 & 26 & 20.1 & 4.3 & 1.9 & 12.5 & 9.8 & 7.6 & 43.8 & 0.0 \\
\hline F2 & 30 & 14.0 & 3.5 & 2.9 & 13.2 & 9.9 & 7.3 & 49.3 & 0.0 \\
\hline F2 & 32 & 11.6 & 3.5 & 2.6 & 9.7 & 21.4 & 12.4 & 38.9 & 0.0 \\
\hline$\overline{F 2}$ & 36 & 10.4 & 5.8 & 3.8 & 12.4 & 21.2 & 17.7 & 28.7 & 0.0 \\
\hline F2 & 40 & 8.9 & 6.9 & 3.4 & 9.5 & 33.8 & 19.3 & 18.3 & 0.0 \\
\hline F2 & 44 & 1.2 & 3.9 & 4.1 & 8.3 & 50.8 & 23.3 & 8.2 & 0.0 \\
\hline F3 & 5 & 0.0 & 10.3 & 6.2 & 0.6 & 29.8 & 22.7 & 8.5 & 22.0 \\
\hline$\overline{F 3}$ & 8 & 0.0 & 2.3 & 9.5 & 5.2 & 22.7 & 15.5 & 13.4 & 31.4 \\
\hline F3 & 12 & 0.0 & 0.5 & 4.7 & 3.3 & 29.8 & 20.7 & 10.2 & 30.7 \\
\hline F3 & 15 & 0.0 & 7.5 & 2.2 & 11.4 & 29.2 & 27.4 & 6.8 & 15.4 \\
\hline F3 & 20 & 0.0 & 9.9 & 3.4 & 7.6 & 27.7 & 25.4 & 11.0 & 15.0 \\
\hline
\end{tabular}


Table S4. Stock forming diatoms ranked by carbon $(C)$ contribution. The $C$ value $\left(\mathrm{ng} \mathrm{L}^{-1}\right)$ is the average of all microscopy samples per cruise. Species marked with asterisks $\left({ }^{\star * *}\right)$ are typical for summer assemblages, as they often form a major component of these communities (Foster and O'Mullan 2008), Gettings et al (2014).

\begin{tabular}{|c|c|}
\hline $\mathrm{F} 1$ & Carbon \\
\hline Lauderia annulata Cleve 1873 & 8325 \\
\hline Chaetoceros Ehrenberg $1844 \mathrm{sg}$ Hyalochaete & 1692 \\
\hline Ditylum (Bailey ex. L.W. Bailey) spp. & 1528 \\
\hline Diatom centric $40-60 \mu \mathrm{m}$ & 191 \\
\hline Diatom disc-like $40-60 \mu \mathrm{m}$ & 138 \\
\hline Cerataulina pelagica (Cleve) Hendey 1937 & 130 \\
\hline Chaetoceros didymus Ehrenberg 1845 & 129 \\
\hline Corethron (Castracane 1886) spp. & 128 \\
\hline Chaetoceros curvisetus Cleve 1889 & 98 \\
\hline Dactyliosolen phuketensis (Sundström) Hasle 1996 *** & 75 \\
\hline \multicolumn{2}{|l|}{$\mathrm{F} 2$} \\
\hline Leptocylindrus mediterraneus (Peragallo) Hasle $1975^{* * *}$ & 235 \\
\hline Proboscia alata (Brightwell) Sundström 1986 & 87 \\
\hline Pseudo-nitzschia seriata Complex (Hasle 1965b, 1971) *** & 51 \\
\hline Pseudo-nitzschia delicatissima Complex (Hasle 1964, 1965b) *** & 16 \\
\hline Guinardia flaccida (Castracane) Peragallo 1892 *** & 14 \\
\hline Chaetoceros Ehrenberg 1844 sg Hyalochaete & 12 \\
\hline Diatom centric $10-20 \mu \mathrm{m}$ & 2 \\
\hline Ditylum (Bailey ex. L.W. Bailey) spp. & 2 \\
\hline Diatom centric disc-like $20-40 \mu \mathrm{m}$ & 2 \\
\hline Corethron (Castracane 1886) spp. & 2 \\
\hline \multicolumn{2}{|l|}{ F3 } \\
\hline Pseudo-nitzschia delicatissima Complex (Hasle 1964, 1965b) *** & 99 \\
\hline Dactyliosolen phuketensis (Sundström) Hasle 1996 *** & 82 \\
\hline Cerataulina pelagica (Cleve) Hendey 1937 & 33 \\
\hline Hemiaulus hauckii Grunow ex. Van Heurck 1882 *** & 20 \\
\hline Bacteriastrum spp Shadbolt 1854 & 15 \\
\hline Proboscia alata (Brightwell) Sundström 1986 & 13 \\
\hline Diatom pennate oblong $80-100 \mu \mathrm{m}$ & 12 \\
\hline Leptocylindrus mediterraneus (Peragallo) Hasle $1975^{* * *}$ & 10 \\
\hline Leptocylindrus danicus Cleve 1889 *** & 9 \\
\hline Chaetoceros Ehrenberg 1844 sg Hyalochaete & 9 \\
\hline
\end{tabular}




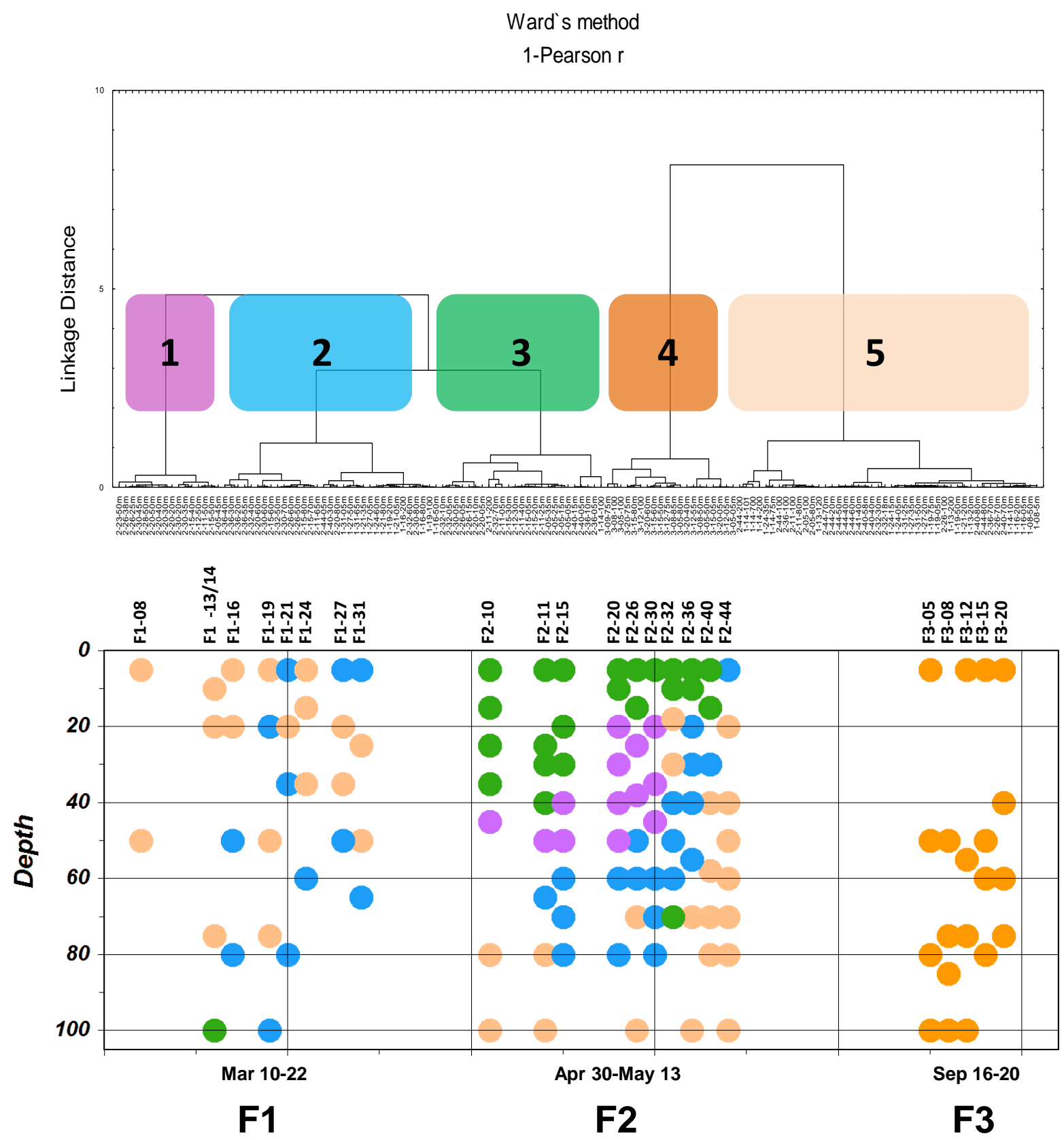

Figure S1. Clustering of samples according to their pigment composition (top panel). Cluster numbers are shown. Sample ascription to clusters (bottom panel). Station numbers are displayed above the top panel; the $\mathrm{x}$-axis represents the temporal scale. 

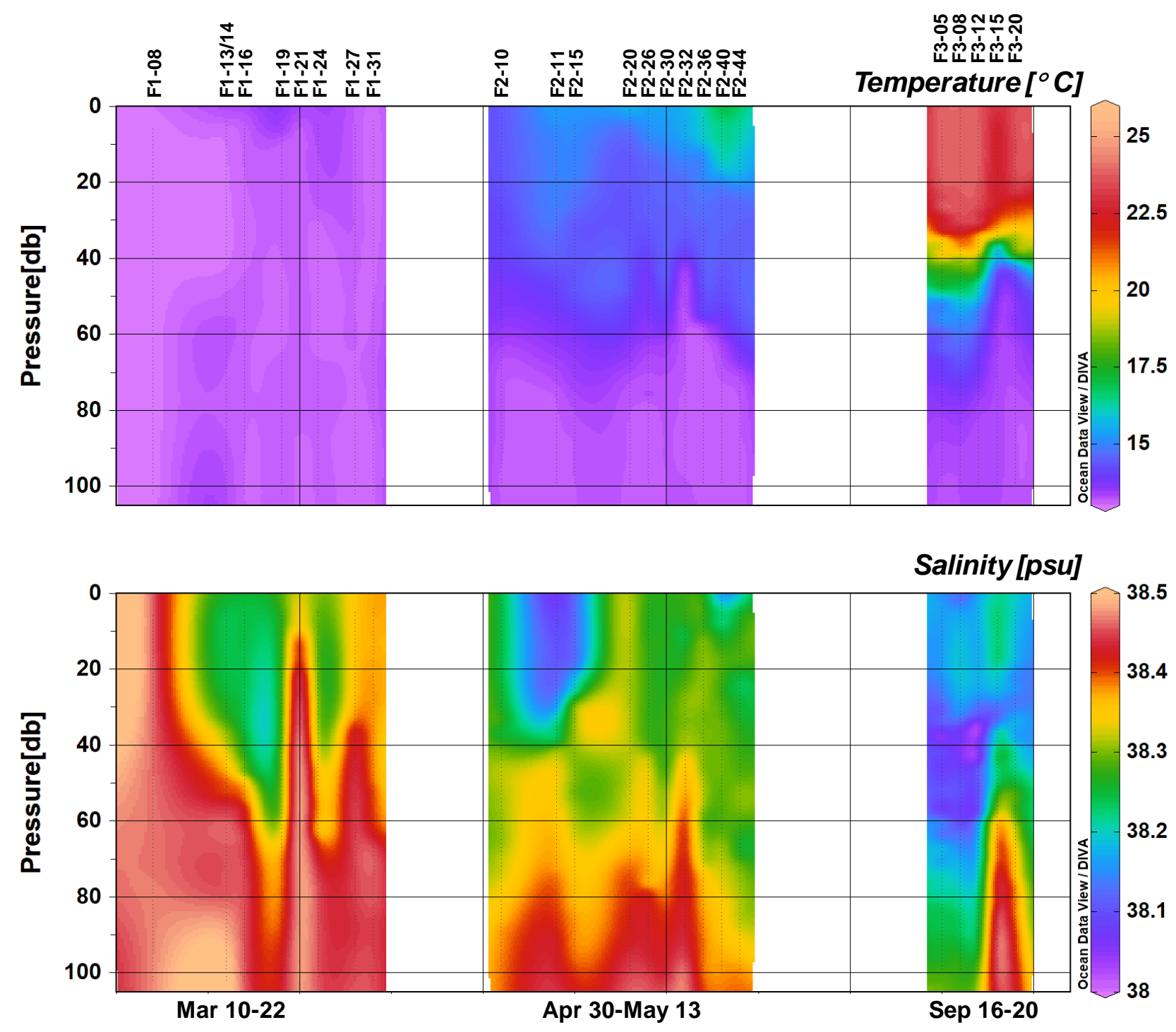

F1

F3

Figure S2. Temperature and salinity in the first $100 \mathrm{~m}$ of the three FAMOSO cruises. Station numbers are displayed above the top panel; the $x$-axis represents the temporal scale. 

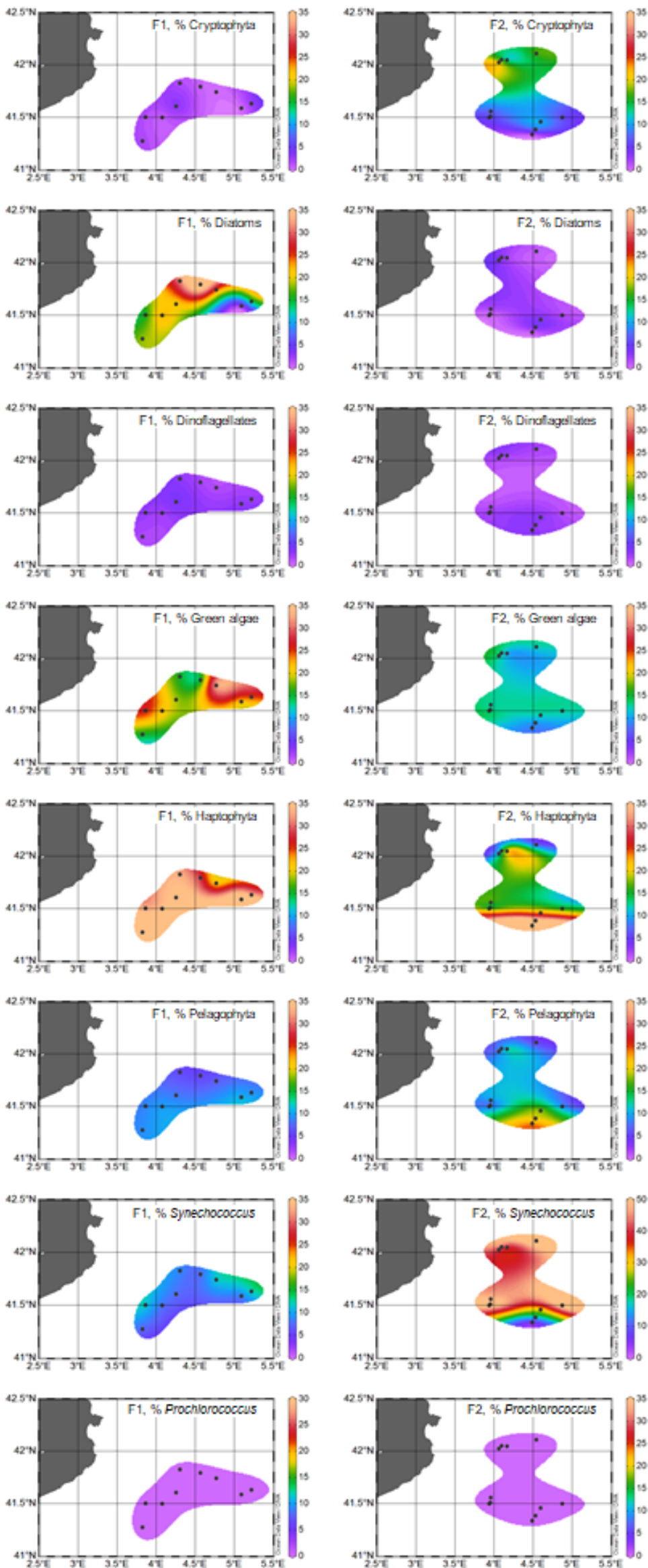


Figure S3. Areal contribution of the different phytoplankton groups to chlorophyll a biomass. Note the different scale for Synechococcus in F2. 

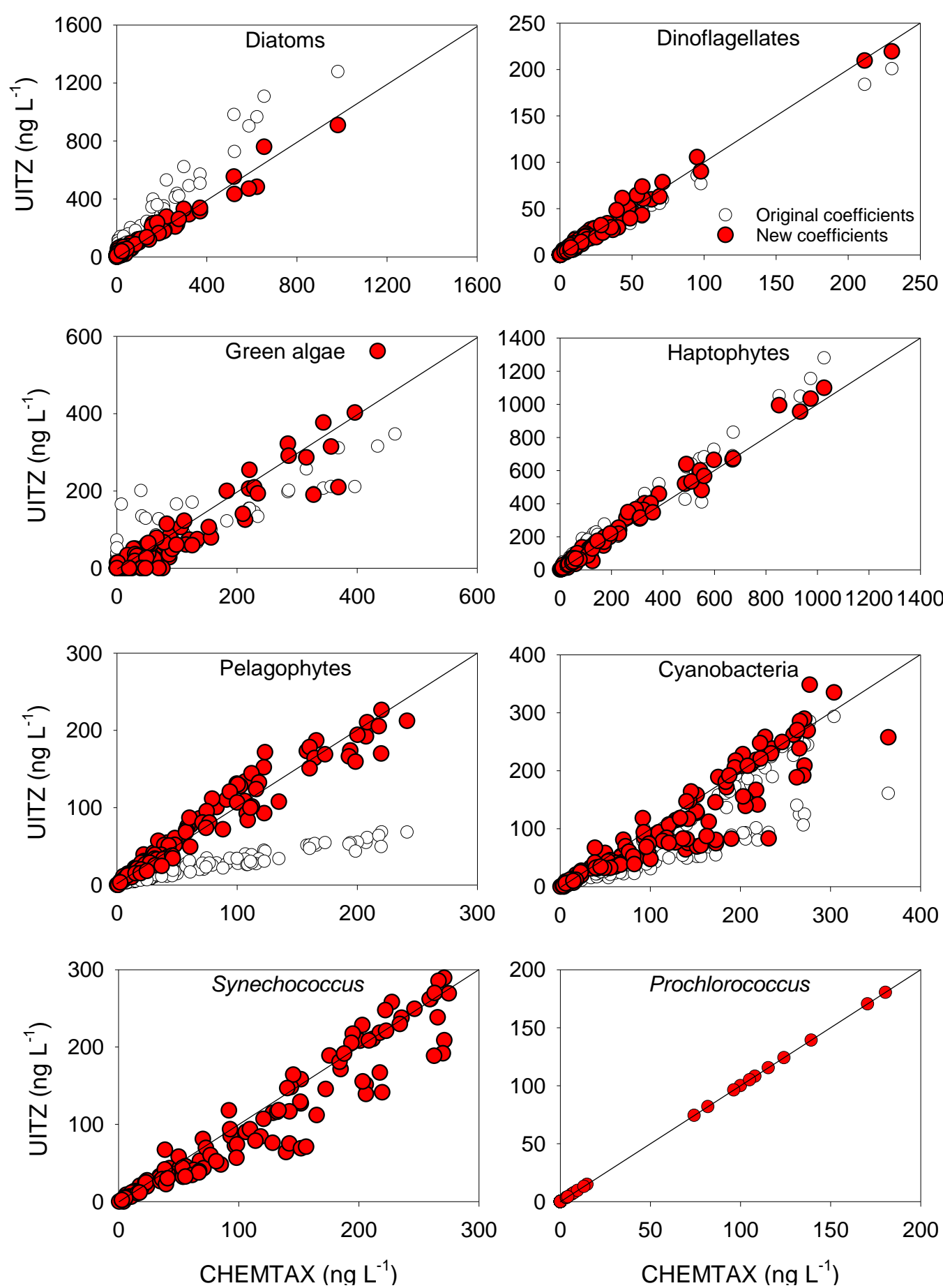

Figure S4. Comparison between CHEMTAX and UITZ methods to estimate the chlorophyll a assigned to the different phytoplankton groups. For the UITZ approach, empty symbols are values estimated according to the original coefficients (Uitz et al 2006), with which Synechococcus and Prochlorococcus contributions cannot be separated (and are estimated as cyanobacteria) and green algae contribution is estimated by subtracting Prochlorococcus contribution to chl b containing groups (Prochlorococcus and green algae); red symbols are the values estimated with the new coefficients tuned for our CHEMTAX results in the area. The resulting new coefficients were 1.15 for alloxanthin (cryptophytes), 0.67 for fucoxanthin (diatoms), 1.47 for peridinin (dinoflagellates), 9.91 for violaxanthin (green algae), 1.04 for 19'hexanoiloxyfucoxanthin (haptophytes), 1.10 for 19 'butanoiloxyfucoxanthin (pelagophytes), and 1.31 for zeaxanthin (cyanobacteria). Since the contribution of Prochlorococcus can be distinguished as divinyl chlorophyll a (DVChl a), the contribution of Synechococcus was estimated as cyanobacteria - DVChl a. 

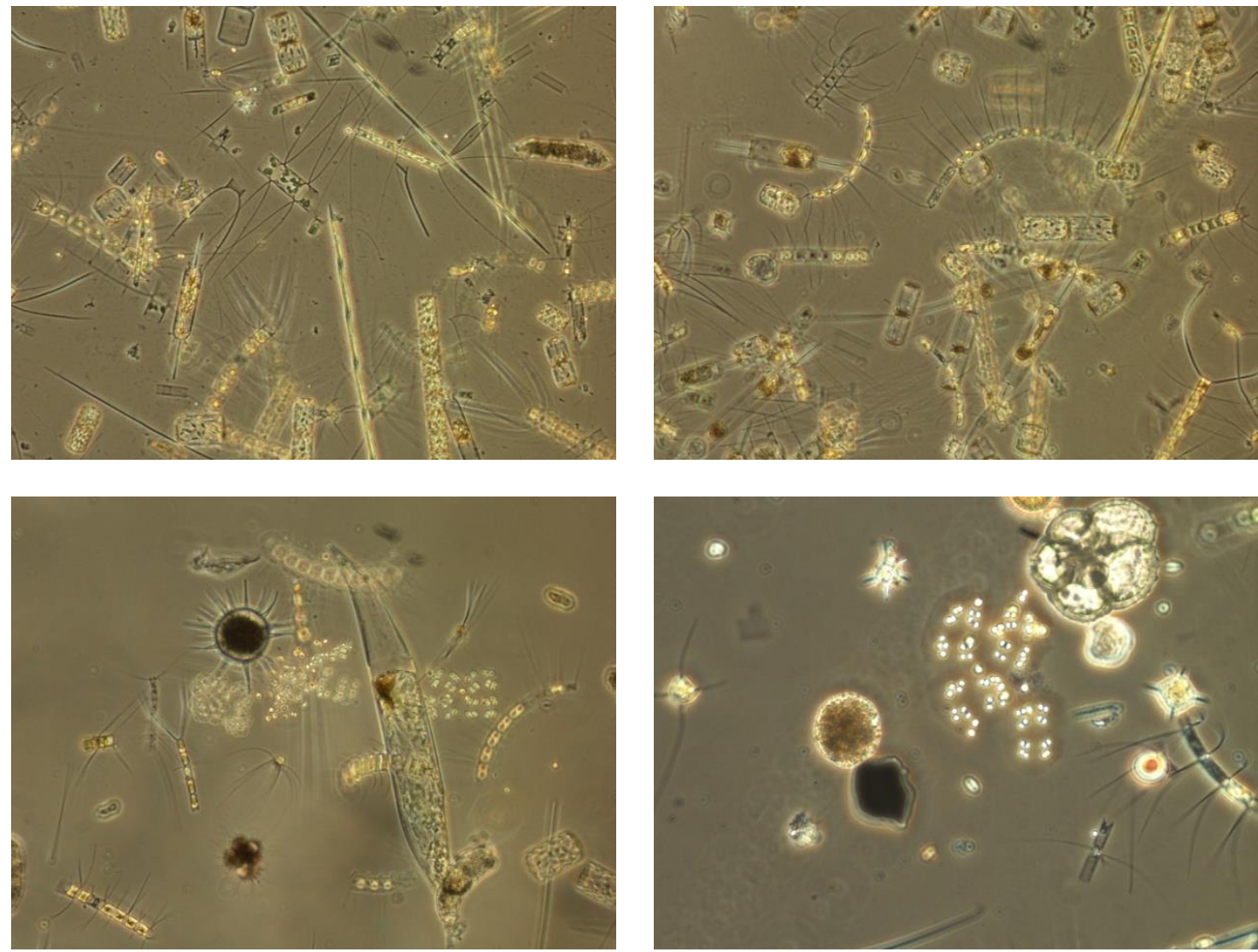

Figure S5. Microscopy pictures of in vivo net samples of a young diatom-dominated community (top panels) and a more mature haptophyte-dominated community (bottom panels) during F1. 

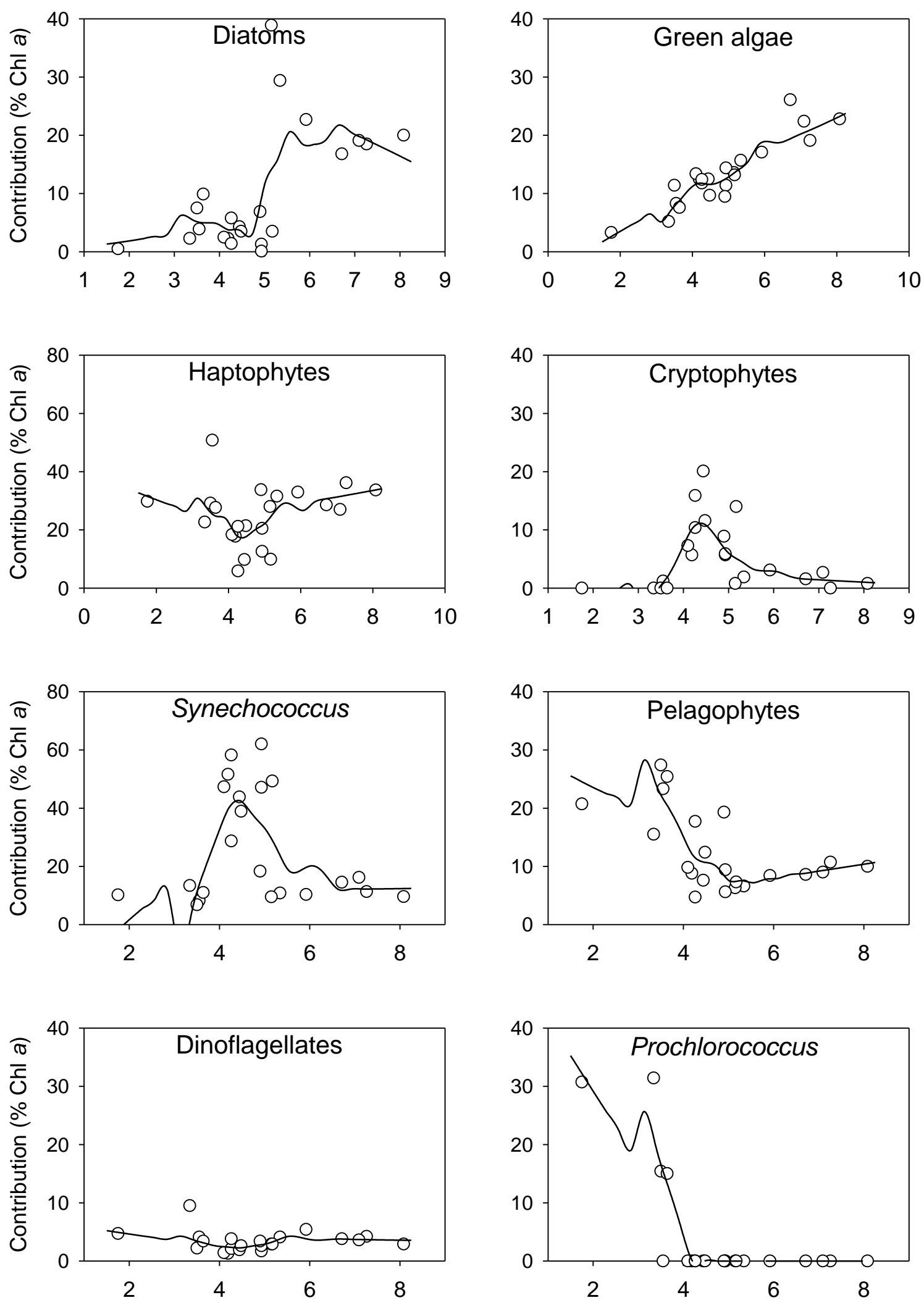

DIN ( $\mu \mathrm{mol} \mathrm{L} \mathrm{L}^{-1}$, average $\left.100 \mathrm{~m}\right)$

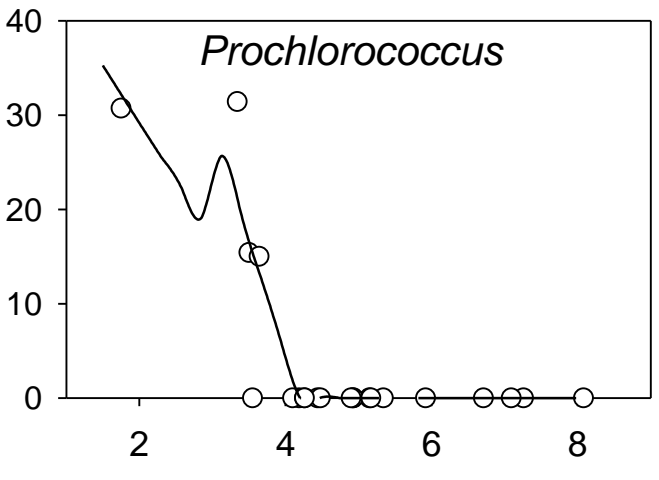

DIN ( $\mu \mathrm{mol} \mathrm{L}{ }^{-1}$, average $100 \mathrm{~m}$ )

Figure S6. Percentage contribution of the different phytoplankton groups along the average concentration of dissolved inorganic (DIN, $\mathrm{NO}_{3}+\mathrm{NO}_{2}$ ) in the upper $100 \mathrm{~m}$. The line represents a smoothed trend (see M\&M). Note the different scale for haptophytes and Synechococcus. 


\section{References}

Foster, R.A., O'Mullan, G.D., 2008. Nitrogen-Fixing and Nitrifying Symbioses in the Marine Environment, in: Capone, D.G., Bronk, D.A., Mulholland, M.R., Carpenter, E.J. (Eds.), Nitrogen in the Marine Environment. Academic Press, Amsterdam, pp. 1197-1218.

Gettings, R. M., D. W. Townsend, M. A. Thomas, and L. Karp-Boss. 2014. Dynamics of late spring and summer phytoplankton communities on Georges Bank, with emphasis on diatoms, Alexandrium spp., and other dinoflagellates. Deep Sea Res. II. 103: 120-138. doi:https://doi.org/10.1016/j.dsr2.2013.05.012

Uitz, J., H. Claustre, A. Morel, S. B. Hooker, H. Claustre, A. Morel, S. B. Hooker, and J. Uitz. 2006. Vertical distribution of phytoplankton communities in open ocean: An assessment based on surface chlorophyll. J. Geophys. Res. 111: C08005. doi:10.1029/2005JC003207 